\title{
Siting Evaluation for Biomass-Ethanol Production in Hawaii
}

October 1999

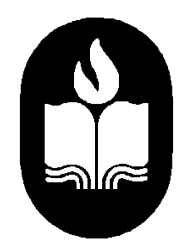

DEPARTMENT OF BIOSYSTEMS ENGINEERING

College of Tropical Agriculture and Human Resources University of Hawaii at Manoa 
This publication was reproduced from the best available copy Submitted by the subcontractor and received no editorial review at NREL

\section{NOTICE}

This report was prepared as an account of work sponsored by an agency of the United States government. Neither the United States government nor any agency thereof, nor any of their employees, makes any warranty, express or implied, or assumes any legal liability or responsibility for the accuracy, completeness, or usefulness of any information, apparatus, product, or process disclosed, or represents that its use would not infringe privately owned rights. Reference herein to any specific commercial product, process, or service by trade name, trademark, manufacturer, or otherwise does not necessarily constitute or imply its endorsement, recommendation, or favoring by the United States government or any agency thereof. The views and opinions of authors expressed herein do not necessarily state or reflect those of the United States government or any agency thereof.

Available electronically at http://www.doe.gov/bridge

Available for a processing fee to U.S. Department of Energy and its contractors, in paper, from:

U.S. Department of Energy

Office of Scientific and Technical Information

P.O. Box 62

Oak Ridge, TN 37831-0062

phone: 865.576 .8401

fax: 865.576 .5728

email: reports@adonis.osti.gov

Available for sale to the public, in paper, from:

U.S. Department of Commerce

National Technical Information Service

5285 Port Royal Road

Springfield, VA 22161

phone: 800.553 .6847

fax: 703.605.6900

email: orders@ntis.fedworld.gov

online ordering: http://www.ntis.gov/ordering.htm 


\title{
Siting Evaluation for Biomass-Ethanol Production in Hawaii
}

\author{
By \\ Charles M. Kinoshita \\ Jiachun Zhou
}

\author{
Prepared for \\ National Renewable Energy Laboratory
}

Under Subcontract XXE-8-17099-01

October 1999

\author{
Department of Biosystems Engineering \\ College of Tropical Agriculture and Human Resources \\ University of Hawaii at Manoa
}




\section{Acknowledgments}

This work was supported by the National Renewable Energy Laboratory, through the "Biomass to Ethanol Infrastructure and Pretreatment Research" Project (Subcontract No. XXE-8-17099-01 to the University of Hawaii, represented by the Biosystems Engineering Department). The authors thank the National Renewable Energy Laboratory for funding this work and for its technical assistance in this investigation.

The completion of this study would not have been possible without the valuable assistance from many individuals and organizations. In particular, the authors recognize the individuals listed below:

Carl Alexander, Hawaiian Commercial \& Sugar Co., Maui, Hawaii

Nicklos Dudley, Hawaii Agricultural Research Center, Honolulu, Hawaii.

Herve Fleisch, Maui Pineapple Company, Maui, Hawaii.

Bruce Hartsough, Agricultural Engineering Department, University of California, Davis.

Randall Moore, Hawaiian Commercial \& Sugar Co., Maui, Hawaii.

Wesley Nohara, Maui Pineapple Company, Maui, Hawaii.

Niel O'Brien, Hilo Coast Processing Company, Hilo, Hawaii.

Robert Osgood, Hawaii Agricultural Research Center, Honolulu, Hawaii.

Mike Serno, Pioneer Mill Company, Maui, Hawaii.

Robert Shleser, Honolulu, Hawaii.

Joseph Sylvester, Amfac Sugar Kauai, Kauai, Hawaii.

Yoshiaki Tanabe, Waialua Sugar Company, Honolulu, Hawaii.

Jim Thain, Forest Solutions, Paauilo, Hawaii.

George Wachi, Gay \& Robinson, Inc., Hawaii.

Art Wiselogel, National Renewable Energy Laboratory, Golden, Colorado.

Russel Yost, University of Hawaii, Honolulu, Hawaii. 


\section{Executive Summary}

This report examines four Hawaiian islands, Oahu, Hawaii, Maui, and Kauai, to identify three best combinations of potential sites and crops for producing dedicated supplies of biomass for conversion to ethanol. Key technical and economic factors considered in the siting evaluation include land availability (zoning and use), land suitability (agronomic conditions), potential quantities and costs of producing biomass feedstocks, infrastructure (including water and power supplies), transportation, and potential bioresidues to supplement dedicated energy crops.

All lands in the State of Hawaii are zoned Conservation, Agricultural, Urban, or Rural, by the State Land Use Commission. Lands presently used for crop production on the four islands occupy only small fractions of the total lands zoned Agricultural - 40,000 acres of crops are grown on 130,000 acres zoned Agricultural on Oahu; 70,000 acres on 1,200,000 acres on Hawaii; 60,000 acres on 250,000 acres on Maui; 50,000 acres on 140,000 acres on Kauai. Thus, large tracts of land sitting fallow have the potential for supporting ethanol-crop production in Hawaii. The acreage in sugarcane in the State has decreased from a high of 255,000 acres in the 1930s to less than 70,000 acres today. Downsizing of the sugar industry offers an unprecedented opportunity for establishing a new agri-energy industry. Efforts have been made to offset the steady loss in sugarcane acreage, mostly with diversified agriculture (e.g., coffee, flowers, and nursery products); however, these crops are not expected to occupy more than a small fraction of the land previously in cane. Large quantities of productive and well developed agricultural lands exist in Hawaii in "ready to plant" condition.

Seven candidate sites in locations zoned Agricultural and presently or previously in commercial agriculture were selected for closer evaluation for ethanol-feedstock production based on land availability and their potential for producing more than 300 tons per day of biomass (dry-weight basis). The seven sites are located in Waialua and Ewa on the island of Oahu, Ka'u and Hamakua/North Hilo on the island of Hawaii, Lahaina and Wailuku/Makawao on the island of Maui, and Koloa/Lihue on the island of Kauai. Three sites were selected from the seven candidates based on land suitability (land ownership, topography, climate, soil, and other agronomic conditions). The three sites selected for final evaluation were: (1) former Waialua Sugar Company (WSCo) in Waialua on Oahu island, with 12,000 acres; (2) Hawaiian Commercial \& Sugar Company (HC\&S) in Wailuku/Makawao on Maui, with more than 20,000 acres; and (3) former Hamakua Sugar Company (HSC) in Hamakua/North Hilo on Hawaii island, with more than 20,000 acres.

Two grass species, sugarcane and banagrass (Pennisetum purpureum), and two tree species, Eucalyptus and Leucaena, were identified as the most promising crops for ethanol production. Sugarcane, which formerly dominated agriculture in Hawaii, produces very high yields of fiber and fermentable sugars (sugarcane grown commercially in Hawaii has an average dry-matter yield of $\sim 18$ tons per acre-year, consisting of about $60 \%$ fiber and $40 \%$ sugar). Long cultivation history and well-developed infrastructure give sugarcane inherent advantages over other crops. A number of biomass experiments have been performed in Hawaii to identify other promising high-yielding energy crops. Banagrass has been demonstrated to attain very high biomass yields and shows strong commercial potential as an energy crop. Banagrass and sugarcane call for similar cultural practices, agronomic conditions, and production infrastructure. They share similar production operations (although several unit operations for banagrass should be simpler and less costly than corresponding sugarcane operations). The projected yield of banagrass, based on several trials performed in Hawaii, is $\sim 22$ tons per acre-year for irrigated fields, and $\sim 18$ tons per acre-year for unirrigated fields. Of the tree species, Leucaena and Eucalyptus offer the best commercial potential owing to their high yields. Numerous small- and medium-scale trials in Hawaii have provided guidelines for optimizing the production of these tree crops. Based on large-plot field trials and on near-commercial-scale plantings in Hawaii, Leucaena and Eucalyptus are anticipated to produce 
commercial yields of $\sim 10$ tons per acre-year. A recently established Eucalyptus plantation on the island of Hawaii will provide additional experience in large-scale tree cultivation.

Production costs from one sugarcane plantation in Hawaii were used as the basis for this cost analysis of ethanol-crop production. The estimated cost for producing sugarcane for conversion to ethanol, FOB conversion-facility gate, is approximately $\$ 85$ per ton (dry-matter basis). The equivalent cost of production for banagrass is about $\$ 66$ per ton, \$54 per ton for Eucalyptus, and \$85 per ton for Leucaena (dry-matter basis). Table A-1 summarizes major assumptions and costs for the four ethanol crops (the cost of land holding is not included in the cost figures).

Table A-1. Major assumptions and estimated costs for producing ethanol crops.

\begin{tabular}{|c|c|c|c|c|}
\hline & \multicolumn{4}{|c|}{ Crop } \\
\hline & $\underline{\text { Sugarcane }}$ & $\underline{\text { Banagrass }}$ & Eucalyptus & $\underline{\text { Leucaena }}$ \\
\hline Dry matter yield (tons/acre-year) & 18 & 22 & 9 & 10 \\
\hline Average crop age (years) & 2 & 0.67 & 5 & 5 \\
\hline Number of ratoons & 0 & 5 & 0 & 3 \\
\hline Irrigation regime & irrigated & irrigated & unirrigated & irrigated \\
\hline Cost (\$/tons, dry-basis) & 85 & 66 & 54 & 85 \\
\hline
\end{tabular}

Each of the selected sites has been and remains (to some extent) in intensive agriculture. Lands taken out of agriculture at the three candidate sites have high yield potential and can be converted to ethanol-crop production relatively easily. Crops evaluated at each site were selected based on their compatibility with the site. Combinations of land size and crop species, each capable of providing at least 300 tons of dry matter per day to an ethanol conversion facility, are presented in Table A-2.

Table A-2. Acreages and quantities of biomass supplies at three sites.

\begin{tabular}{|c|c|c|c|}
\hline$\underline{\text { Site }}$ & $\frac{\text { Acreage }}{\text { (acres) }}$ & Crop & $\frac{\text { Biomass Supply }}{\text { (tons/day) }}$ \\
\hline WSCo on Oahu & $\sim 12,000$ & $\begin{array}{l}\text { Sugarcane } \\
\text { Banagrass }\end{array}$ & $\begin{array}{l}720^{1} \\
880^{1}\end{array}$ \\
\hline HC\&S on Maui & $\sim 20,000$ & $\begin{array}{l}\text { Sugarcane } \\
\text { Banagrass }\end{array}$ & $\begin{array}{l}1,200^{1} \\
1,467^{1}\end{array}$ \\
\hline $\begin{array}{l}\text { HSC on Hawaii } \\
\text { 1. Assumes irri } \\
\text { 2. Assumes uni }\end{array}$ & $\begin{array}{l}\sim 20,000 \\
\text { ns. }\end{array}$ & Eucalyptus & $667^{2}$ \\
\hline
\end{tabular}

Residues produced by other agricultural activities in Hawaii and municipal solid wastes (MSW) contain significant amounts of lignocellulosic material that can supplement or replace dedicated energy crops as feedstocks for ethanol conversion. Agricultural residues considered include those from sugarcane, pineapple, macadamia nut, and coffee production. The composition and quantity of MSW vary widely depending on location. One important component in MSW, paper waste, was included in this investigation (because of anticipated difficulties in collection and inconsistencies in supplies, no other MSW component was considered). A substantial amount of bioresidues and waste material can be collected on Oahu and 
Maui to supplement dedicated ethanol crops at the WSCo and HC\&S sites, respectively. Quantities of residues available at the three selected sites are presented in Table A-3.

Table A-3. Quantities of residues available at three sites.

\begin{tabular}{|c|c|c|}
\hline$\underline{\text { Site }}$ & $\underline{\text { Residue }}$ & $\frac{\text { Quantity }}{\text { (tons/day) }^{1}}$ \\
\hline \multicolumn{3}{|c|}{ WSCo on Oahu } \\
\hline & Paper (1991 data) & 945 \\
\hline & Total & 945 \\
\hline \multicolumn{3}{|c|}{ HC\&S on Maui } \\
\hline & Paper (1991 data) & 233 \\
\hline & Sugarcane bagasse (1997 data) & 1,038 \\
\hline & Sugarcane trash (1997 data) & 560 \\
\hline & Pineapple silage & 27 \\
\hline & Total & 1,858 \\
\hline \multicolumn{3}{|c|}{ HSC on Hawaii } \\
\hline & Paper (1991 data) & 134 \\
\hline & Forest residues (Eucalyptus plantation) & 30 \\
\hline & Total & 164 \\
\hline
\end{tabular}

In addition to high yield and acceptable production cost, successful energy-crop production and ethanol conversion depend on the adequacy of infrastructure at the plantation and the conversion facility, including those for electricity, water, and transportation. All three sites have abundant and stable groundwater resources. Each site also has good surface water collection and delivery systems. The supply capacity for water sources at each site is adequate to meet the requirements of ethanol-crop production.

Oil, coal, biomass and other types of fuels are used for power generation in Hawaii. Electricity generation capacity comfortably exceeds electricity consumption on each island housing the three candidate sites. The existing power distribution systems at the three sites can easily serve energy-crop production and ethanol conversion.

Ground transportation on each island relies on the existing system of highways. Each site is connected to the primary transportation network on the island and is easily accessible to most areas of the island, including airports and harbors. The agricultural land at each site is interconnected by a complete road network which provides efficient transportation conditions for the biomass feedstock to reach the ethanol conversion facility. Each island that houses a selected biomass production site has at least one deepdraft harbor with facilities for containerized cargo. The distance from each site to the nearest harbor or airport on the island ranges from $\sim 2$ miles to 50 miles. Closure of sugar plantations at the WSCo and HSC sites has idled valuable inventories of other supporting infrastructure, such as drainage systems, processing facilities, fabrication and maintenance shops, and warehouses. The existing infrastructure at each site is well situated and equipped to service a new biomass-to-ethanol industry. 


\section{Table of Contents}

Acknowledgments

. v

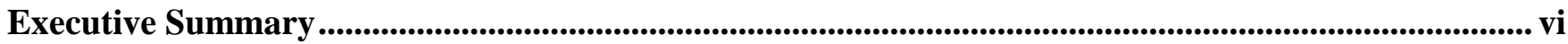

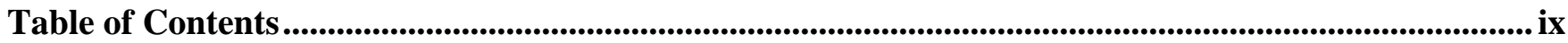

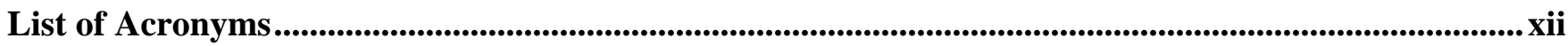

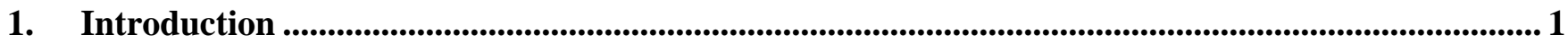

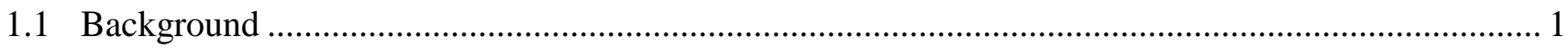

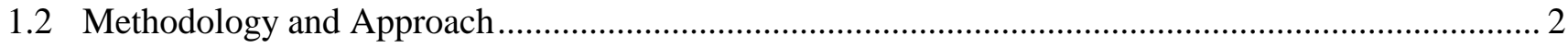

2. Overview of State of Hawaii: General Description, Energy Problems and Regulations, Past Experiences with Alternate Fuels ...............................................................................................

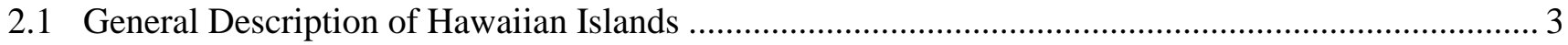

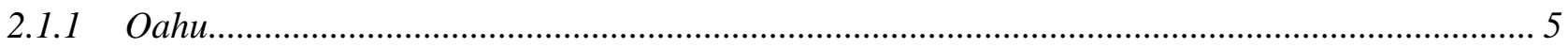

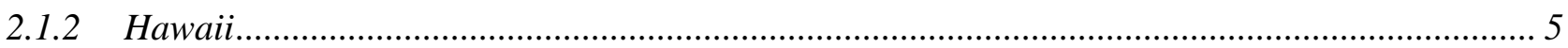

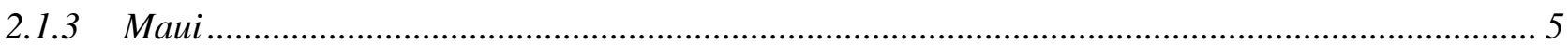

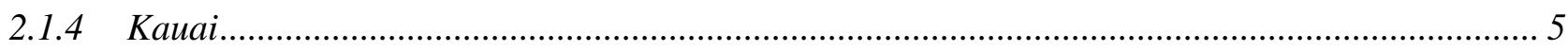

2.2 Energy Problems and Regulations that Could Impact Ethanol Production in Hawaii....................... 6

2.3 Previous Experiences with Alternate Fuels in Hawaii ............................................................. 7

3. Candidate Ethanol-Crop Selection ............................................................................................................................ 9

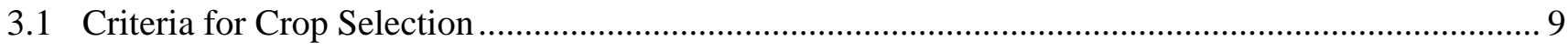

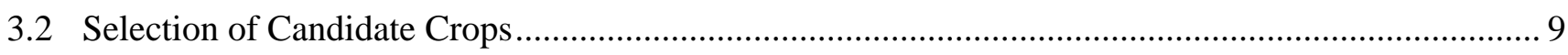

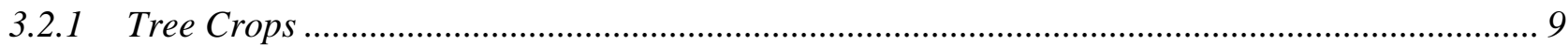

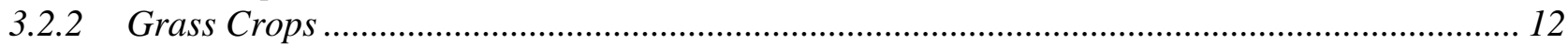

3.3 Projections of Commercially Achievable Yields of Candidate Crops ........................................... 15

3.4 Ethanol Yield Potential of Candidate Crops ......................................................................... 16

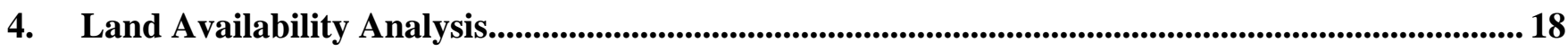

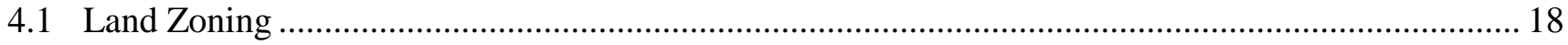

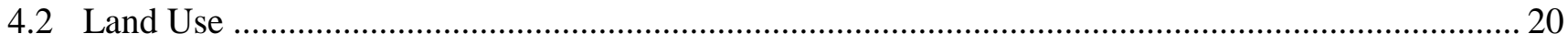

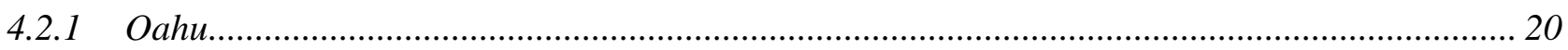

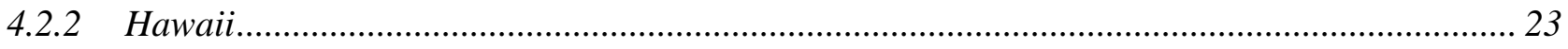

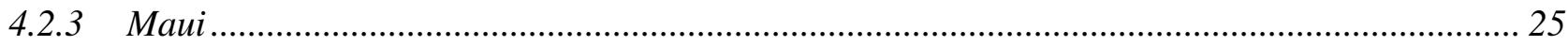

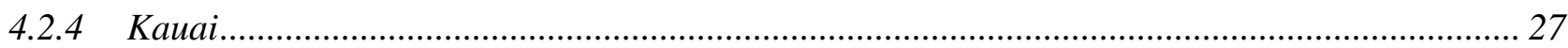

4.3 Candidate Sites — Results of Land Availability Analysis...................................................2 28

5. Suitability of Candidate Sites …................................................................................................................ 30

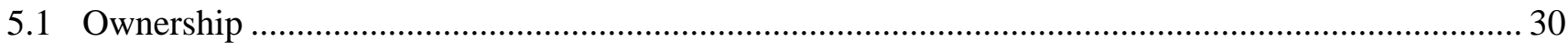

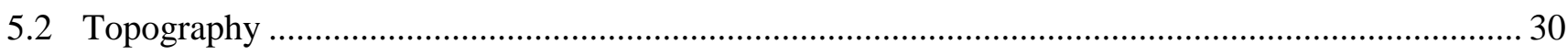


5.3 Climatic Conditions

5.4 Soil

5.5 Selection of Three Most Suitable Sites

6. Ethanol-Crop Production and Cost Predictions

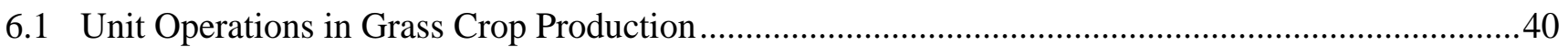

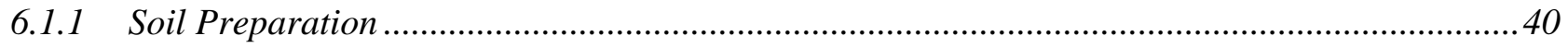

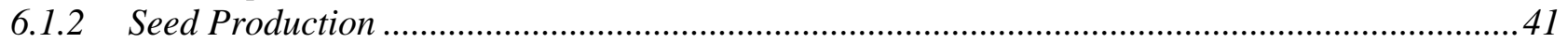

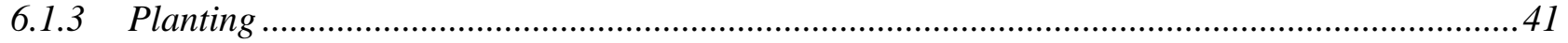

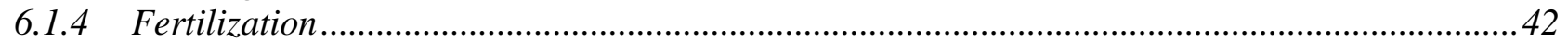

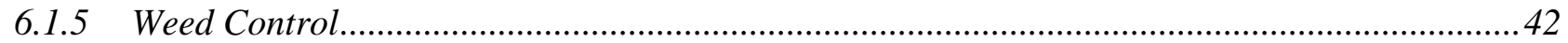

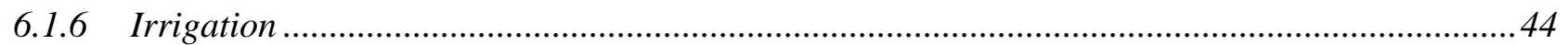

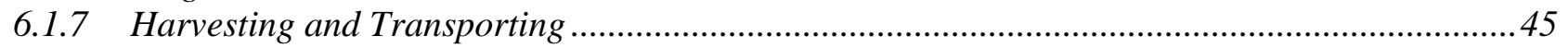

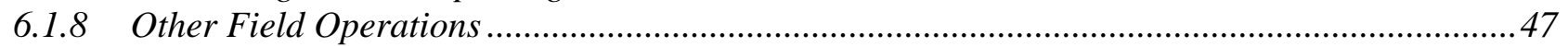

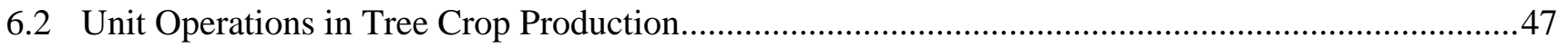

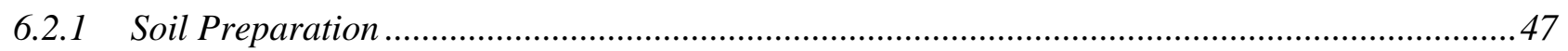

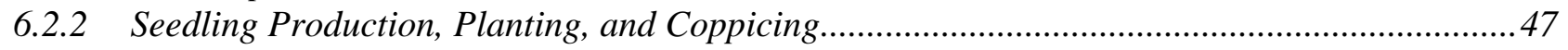

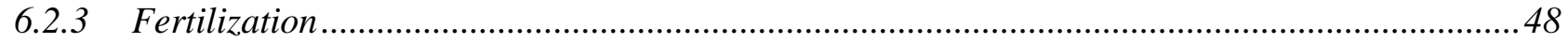

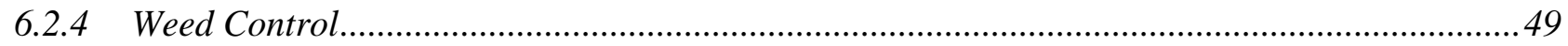

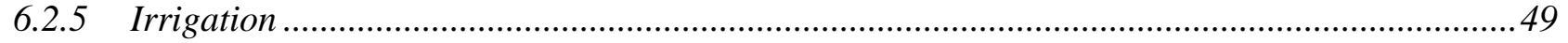

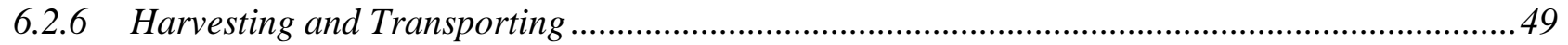

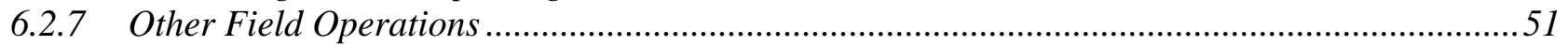

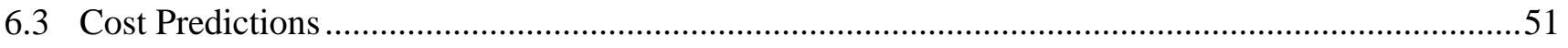

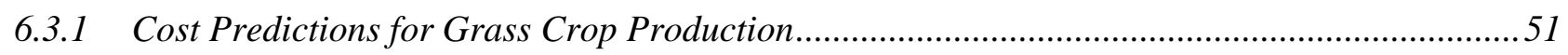

6.3.2 Cost Predictions for Tree Crop Production .......................................................................5

7. Case Study 1 — Former Waialua Sugar Company Site...............................................................58

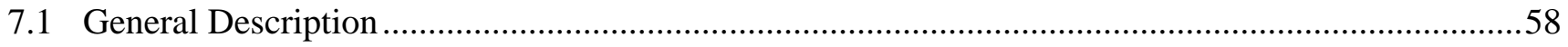

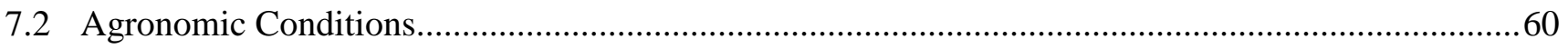

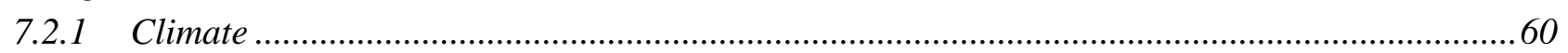

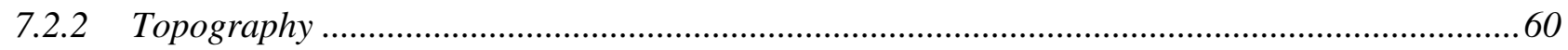

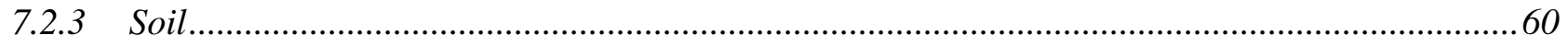

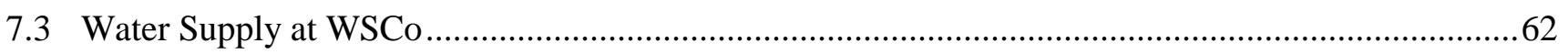

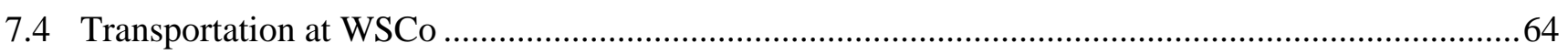

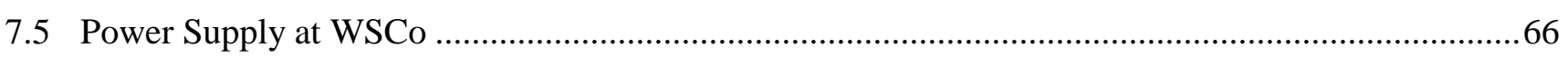

7.6 Candidate Ethanol Crops and Their Output Potential at WSCo Site .............................................68

7.7 Potential Bioresidue Supplies for Ethanol Production ..............................................................68

8. Case Study 2 - Hawaiian Commercial \& Sugar Company Site ..............................................................70

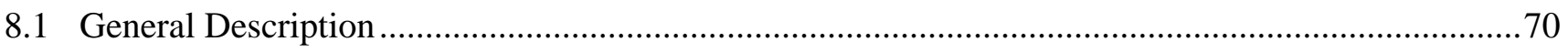

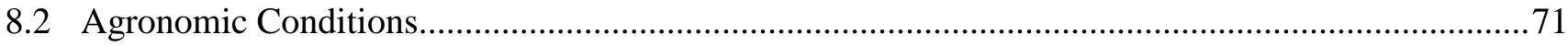

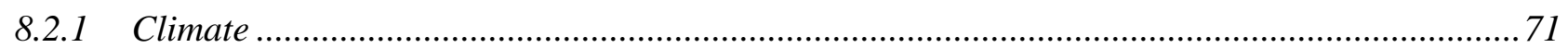

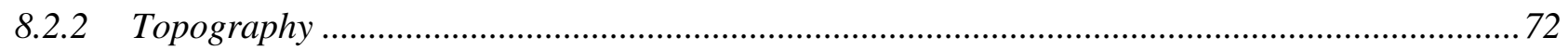

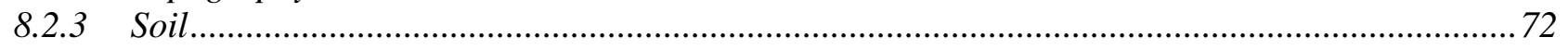

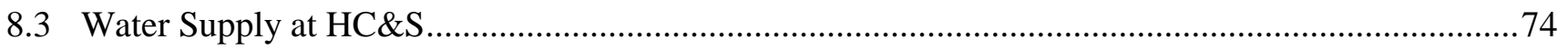

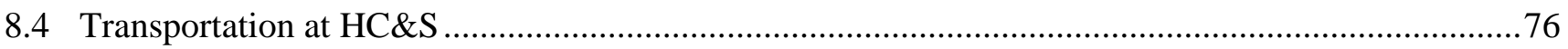




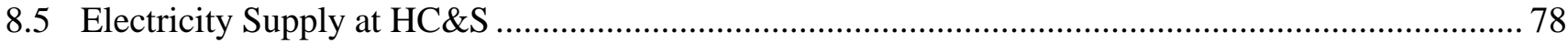

8.6 Candidate Ethanol Crops and Their Output Potential at HC\&S Site............................................ 80

8.7 Potential Bioresidues for Ethanol Production at HC\&S Site ........................................................ 80

9. Case Study 3 — Former Hamakua Sugar Company Site ....................................................................... 82

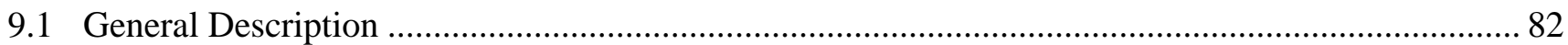

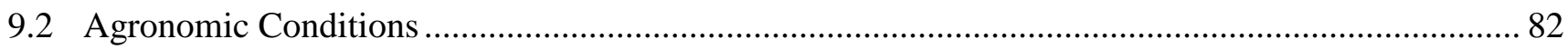

9.2.1 Climate

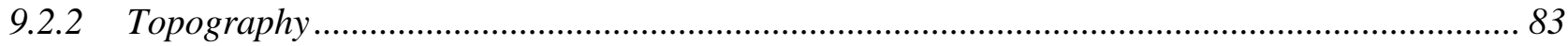

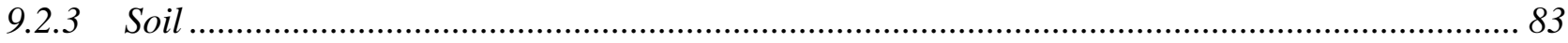

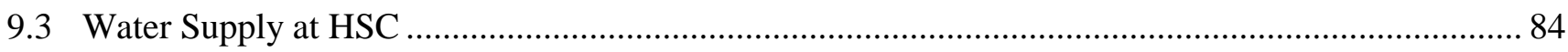

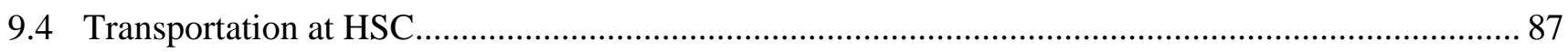

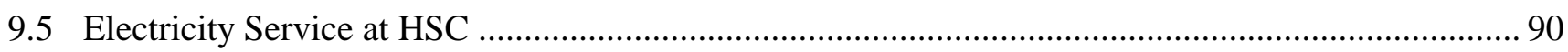

9.6 Candidate Ethanol Crops and Their Output Potential at HSC Site............................................... 91

9.7 Potential Bioresidues for Ethanol Production at HSC Site ....................................................... 91

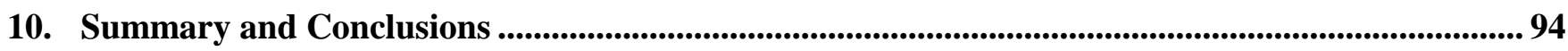

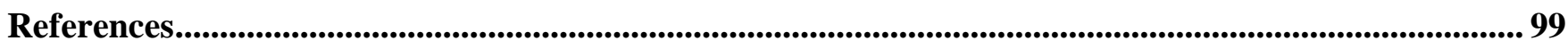




\section{List of Acronyms}

A\&B Alexander \& Baldwin, Inc.

AFVs alternate fuel vehicles

BWS Board of Water Supply

DBEDT Department of Business, Economic Development, and Tourism (State of Hawaii)

EMI East Maui Irrigation Co.

EPACT National Energy Policy Act

GSP Gross State Product

HARC Hawaii Agriculture Research Center

HC\&S Hawaiian Commercial \& Sugar Co.

HCPC Hilo Coast Processing Company

HECO Hawaiian Electric Company, Inc.

HEI Hawaiian Electric Industries Inc.

HELCO Hawaii Electric Light Co.

HHC Hawaiian Homes Commission

HNEI Hawaii Natural Energy Institute

HSC Hamakua Sugar Co., Inc.

HSPA Hawaiian Sugar Planter's Association

MECO Maui Electric Company, Inc.

mgd million gallons per day

MSW municipal solid wastes

NREL National Renewable Energy Laboratory

PICHTR Pacific International Center for High Technology Research

PUC Public Utilities Commission

USDA United States Department of Agriculture

USDOE United States Department of Energy

WSCo Waialua Sugar Company 


\section{Introduction}

\section{$1.1 \quad$ Background}

The specific geographical characteristics of the Hawaiian Islands, being remote and isolated from continental masses, give rise to unique problems relating to energy supply and security. Nearly $95 \%$ of the energy consumed in the State of Hawaii comes from imported fossil fuels, mostly petroleum, and the percentage of energy derived from petroleum resources is higher in Hawaii than in any other state in the nation (the national average being slightly over 40\%). Hawaii's residents pay among the highest prices in the nation for gasoline, residential fuel gas, and electricity. Security of energy supplies has been a major concern for Hawaii's residents and will be a factor in future economic development. A major component of the energy demand mix in the State is the transportation sector, which, excluding aviation fuels, uses about $40 \%$ of the total imported petroleum.

Hawaii depends on imported petroleum for all of its transportation energy needs. Nearly two-thirds of Hawaii's transportation fuel demand is for aviation uses; the balance is used for ground and marine transportation. This high dependence on imported petroleum has many deleterious effects on Hawaii's economy and environment. First, fuel payments leave the local economy, preventing the creation of jobs and strengthening of the economy. Second, Hawaii is extremely vulnerable to oil embargoes, supply disruptions, and other energy emergencies. And third, environmental risks such as the potential for catastrophic damage to the fragile island ecosystem from oil spills, are increased. In light of the above, securing alternative (i.e., non-fossil) energy resources, such as wind, geothermal, ocean thermal, solar, and biomass energy, has been a high priority in the energy strategy of the State of Hawaii.

Biomass is often viewed as having much potential for supplanting a significant portion of Hawaii's imported fossil fuels in generating electricity and producing transportation fuels. Hawaii's tropical climate provides ideal conditions for producing biomass. Fast-growing energy crops and agricultural residues represent the most abundant and readily available indigenous energy resources in Hawaii. Biomass, grown in a sustained manner for energy applications, releases zero net $\mathrm{CO}_{2}$ to the atmosphere over the life cycle of the biomass resource, thereby reducing the potential for global warming. Development of such alternative energy resources could provide new or expanded markets for agribusiness in Hawaii and improve energy security for the State.

Ethanol is being used in many locations in the U.S. as a substitute for or additive to gasoline in transportation fueling. Ethanol, which can be made from renewable resources, burns cleaner than gasoline, is less toxic, and can increase the octane rating of fuel (a 10\% blend with gasoline raises fuel octane by about 3 points). Ethanol production and utilization have attracted public and commercial interest in Hawaii for several reasons. Ethanol is produced from agricultural products that can be grown locally instead of from imported materials. Feedstocks for ethanol production can come from crops grown specifically for energy such as sugarcane, or agricultural residues such as bagasse, yard and wood waste, and waste paper. The use of agricultural residues could improve the profitability of agriculture in Hawaii and reduce the cost of producing ethanol. Large tracts of sugarcane lands have been taken out of production and are now available for producing alternative crops that can serve as feedstocks for ethanol. Ethanol offers new opportunities for the declining sugar industry, and the opportunity for economic diversification in Hawaii.

To facilitate the attainment of synergistic benefits afforded by an agriculture-based alternative transportation fuel industry in Hawaii, the University of Hawaii, under contract with the National Renewable Energy Laboratory (NREL) of the U.S. Department of Energy (USDOE), is investigating the potential for producing ethanol from biomass. The project, entitled "Biomass to Ethanol Infrastructure and Pretreatment 
Research," is composed of two tasks: (1) Siting Evaluation for Biomass-Ethanol Production in Hawaii and (2) Pretreatment Research. This report presents findings of the former task.

The primary objective of the present investigation (Task 1) is to identify potential plantation sites, crops, and residues that could be used for lignocellulosic-ethanol production in Hawaii. This report identifies crop/site combinations with the capability of supplying 300-1,000 tons (dry-basis) of biomass feedstocks per day on the four major islands in the State of Hawaii, Oahu, Hawaii, Maui, and Kauai.

\subsection{Methodology and Approach}

In this investigation, candidate sites for ethanol-crop production on four islands were first screened on the basis of land availability. The screened sites then were reexamined to determine the most favorable site/crop combinations based on land suitability and other factors.

The investigation was organized as shown below:

- Review of energy problems and strategies, and their impact on ethanol production in Hawaii.

- Identification of energy crops best suited for cultivation and conversion to ethanol.

- Identification of potential sites having lands available and suitable for dedicated biomass-for-ethanol production.

- Selection of the three most favorable sites having the capability of supplying 300-1,000 tons of biomass feedstock per day (dry basis).

- Examination of energy-crop production strategies and unit operations, and projection of crop yields and costs of delivering biomass to a central ethanol conversion facility.

- Examination of resources and infrastructure at the three selected sites, and identification of best site/crop combinations for each site.

- Identification of types and quantities of bioresidues available to supplement dedicated energy crops for ethanol production at each site.

This report is organized along similar lines. Chapter 2 provides a general description of the four Hawaiian islands being considered, reviews energy problems and energy strategies, discusses their impacts on ethanol production in Hawaii, and summarizes previous experiences with alternative fuels. Chapter 3 describes the energy-crop species selected in the screening process and provides yield projections for the selected species. Chapters 4 and 5 describe detailed land availability and suitability analyses used in selecting the three most favorable sites for ethanol production. Chapter 6 describes cultivation, harvesting, transportation, and other unit operations for the selected energy crops and projects costs associated with those operations. Chapters 7 to 9 provide case studies for three selected sites, covering infrastructure, suitable energy crops and their yields, and quantities of bioresidues available to supplement dedicated energy crops. Chapter 10 summarizes the findings of this investigation. 


\section{Overview of State of Hawaii: General Description, Energy Problems and Regulations, Past Experiences with Alternate Fuels}

\subsection{General Description of Hawaiian Islands}

Located between 19 and 22 degrees north latitude, Hawaii is the southernmost state in the United States (Figure 2-1). It is situated almost in the center of the Pacific Ocean and is one of the most isolated yet populous places on Earth. Hawaii is one of the smallest states in the country. The 6,425 square miles (16,640 square kilometers) of land consists of a cluster of Pacific islands, eight large islands and 124 small islands, reefs, and shoals (Figure 2-2). The eight major islands of the archipelago - Hawaii, Maui, Oahu, Kauai, Molokai, Lanai, Niihau, and Kahoolawe (in order of decreasing land size) - make up more than $99 \%$ of the total land area of the State.

Hawaii generally has a tropical climate, although changes in elevation generate variation. Because of the effect of mountains on wind patterns, most islands have distinct windward and leeward patterns of rainfall. Coastal areas are generally drier than the interior uplands. The warm tropical temperatures are usually ameliorated by persistent trade winds. The surrounding ocean keeps temperatures of land areas from becoming extremely warm (the average temperature of the surrounding ocean ranges from about $74-75^{\circ} \mathrm{F}$ in March to $79-80^{\circ} \mathrm{F}$ in September). As the result, the annual variation in mean monthly temperatures is only about $9^{\circ} \mathrm{F}$ for areas near sea level. For example, the daily temperature in Honolulu (capital of the State) varies from $81^{\circ} \mathrm{F}$ to $67^{\circ} \mathrm{F}$ in January and $90^{\circ} \mathrm{F}$ to $74^{\circ} \mathrm{F}$ in September. Hawaii's pleasant climate and other natural resources have attracted tourists and greatly impacted its economic development.

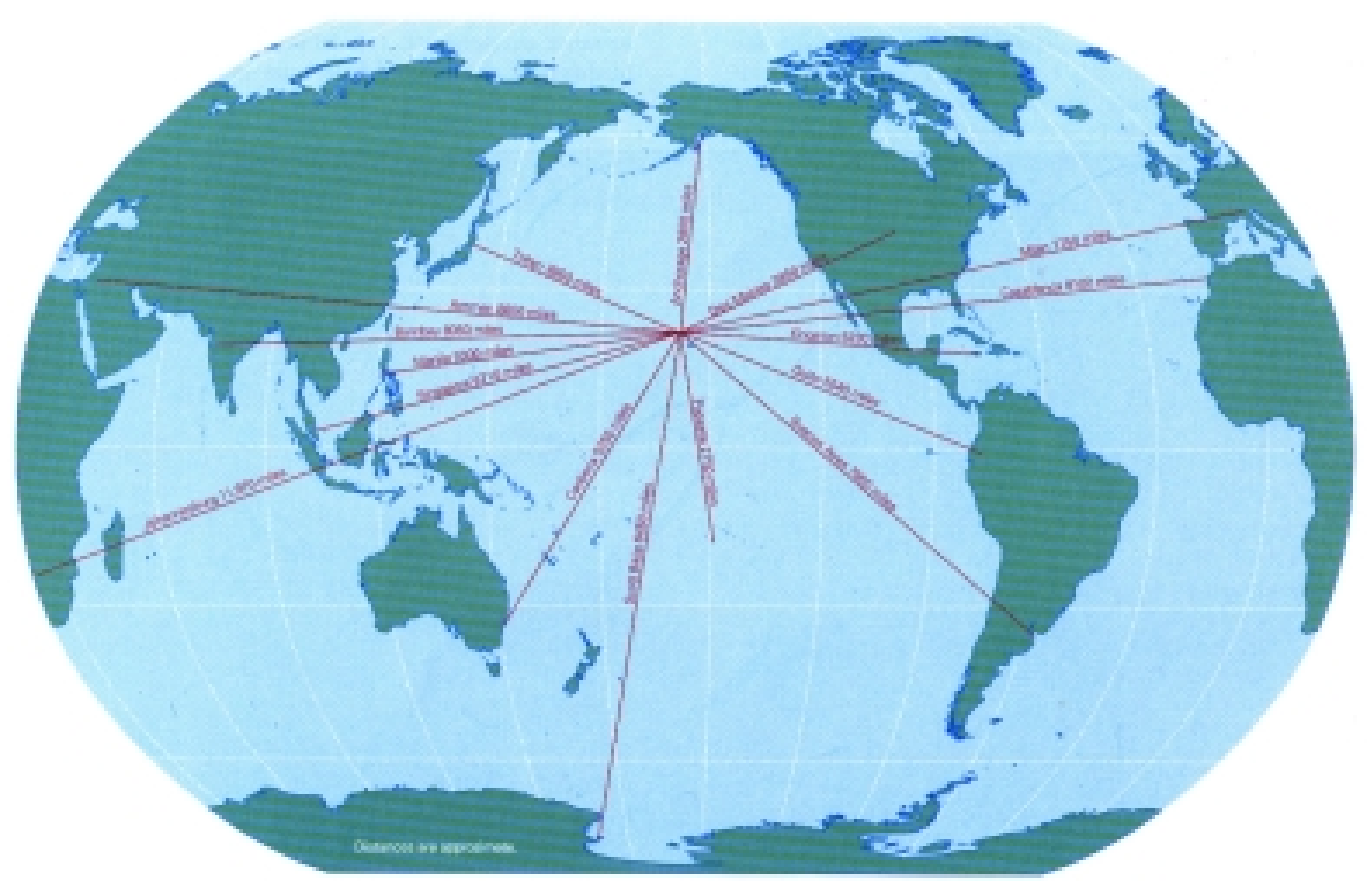

Fig. 2-1. Location of Hawaiian Islands on the globe.

The contemporary economy of Hawaii is structured around the state's dominant source of export earnings, tourism. The other economic mainstays are federal defense spending and agriculture. 

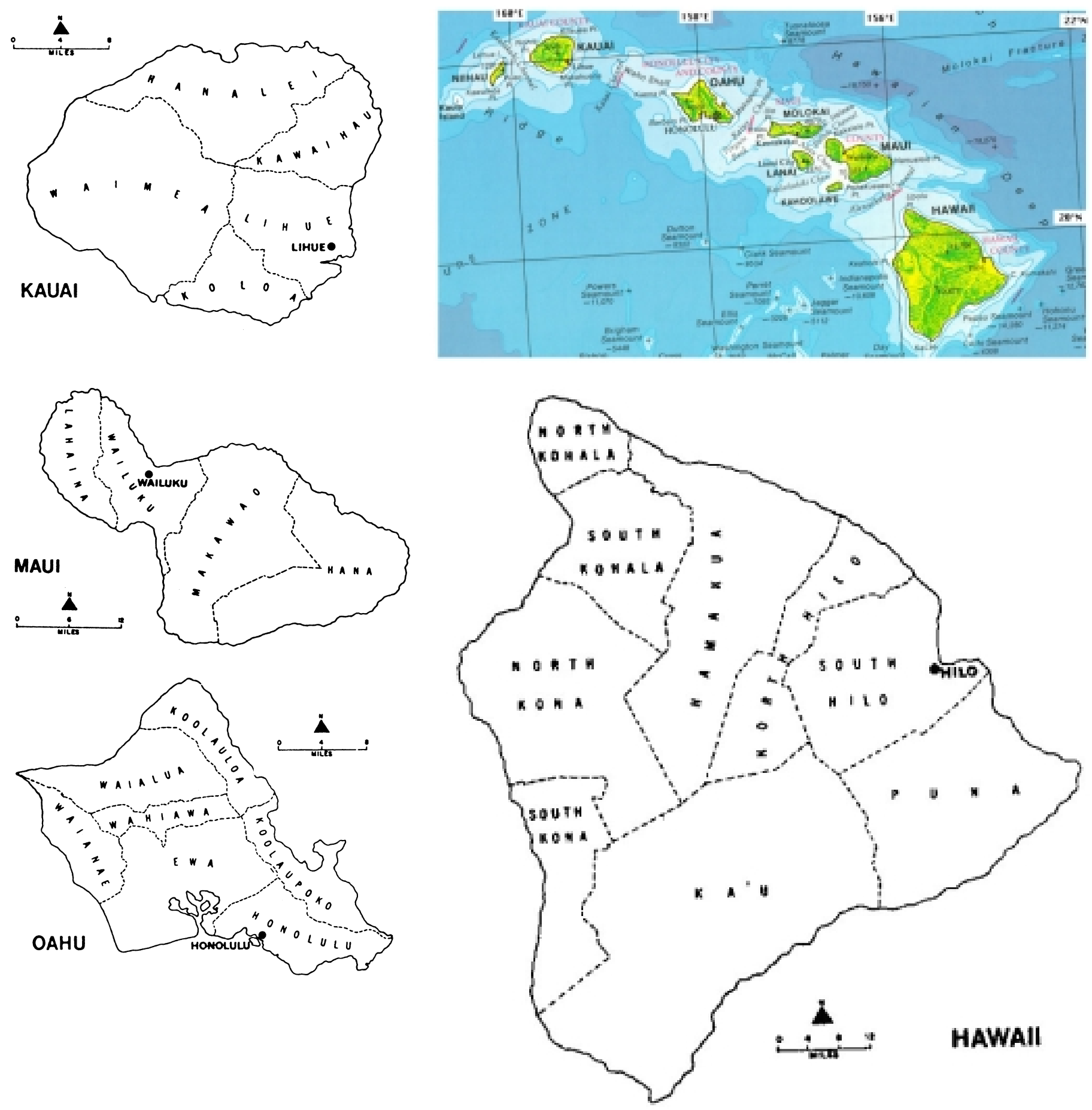

Fig. 2-2. Map of state of Hawaii and districts of four islands.

During the first half of this century, agriculture dominated the economy of Hawaii. With sugarcane and pineapple being the dominant crops. Since the middle of this century, however, agriculture has diminished in economic importance. In 1994, less than $1 \%$ of the Gross State Product (GSP) was derived directly from agriculture (Hawaii's GSP was $\$ 33.5$ billion and per capita personal income was $\$ 25,159$ in 1996). Although sugarcane and pineapple are still important, the State's agriculture in the 1990s has been shifting decisively away from these two plantation crops toward diversified crops. 
Hawaii's transportation network differs from those of other states in the country. Hawaii is the only state that must rely entirely upon air and sea transportation for exports and imports.

The State's lack of self-sufficiency in agriculture and industry creates an imbalance between westward and eastward trade, causing a major back-haul problem for both air and sea carriers. This imbalance is reflected in high freight rates. Private vehicles are, by far, the major form of transportation for residents commuting to work and general activities. All major indicators of road transportation use are rising. For example, the number of registered passenger vehicles (automobiles, pickup trucks, and vans) increased from around 600,000 in 1984 to more than 691,000 (586 motor vehicles per 1,000 population) in 1994. The fuel consumption of motor vehicles increased from about 368 million gallons in 1987 to about 422 million gallons in 1997.

The State of Hawaii is divided into four counties: Hawaii, Maui, Oahu, and Kauai. The county is the lowest civil subdivision in the state. Each county consists of one or more islands. Most of the social and economic activities in the state take place on the five largest islands, namely Hawaii, Maui, Oahu, Kauai, and Molokai. The island of Molokai, investigated previously for energy-crop production (Hubbard and Kinoshita, 1993), is not included in this analysis. Descriptions of the other four major islands follow.

\subsubsection{Oahu}

The island of Oahu, or the City and County of Honolulu, with 608 square miles (1,574 square kilometers) of total land area, is the third largest of the Hawaiian islands, and houses the state capital, Honolulu. In 1996, 872,000 people, or about 74\% of the State's population, resided on Oahu. More than $80 \%$ of the 1995 gross state product of $\$ 32.8$ billion was generated on that island (University of Hawaii, 1983; University of Hawaii at Hilo, 1998). The island is divided into seven districts: Honolulu, Ewa, Wahiawa, Waianae, Waialua, Koolauloa, and Koolaupoko. A map of Oahu showing those districts is presented in Figure 2-2.

\subsubsection{Hawaii}

The island of Hawaii, or Hawaii County, with an area of 4,038 square miles (10,458 square kilometers), holds almost two thirds of the land mass of the entire State. The population of the island was about 138,400 in 1996. The combined value of diversified agriculture on the island was $\$ 133$ million in 1995, down from $\$ 150$ million in 1989 due to ceasing of sugar production on the island. There are nine districts in Hawaii County: Puna, North Hilo, Hamakua, North Kohala, South Kohala, North Kona, South Kona, and Ka'u (Figure 2-2).

\subsubsection{Maui}

Maui County consists of three major islands, Maui, Molokai, and Lanai, and an uninhabited island, Kahoolawe. The island of Maui, with an area of 734 square miles (1,902 square kilometers), is the most populated and economic-intensive island in Maui County. The population of this island is about 92,000. Agricultural production, including sugar and pineapple operations, is stable on Maui unlike on the other islands where those operations have been in decline. Diversified agriculture, primarily in the cooler, upland slopes, growing temperate vegetables and fruits, is expanding rapidly. There are four districts on Maui island: Lahaina, Wailuku, Makawao, and Hana (Figure 2-2).

\subsubsection{Kauai}

The County of Kauai includes the islands of Kauai and Niihau. The island of Kauai is the northern most major island of the Hawaiian archipelago, located about 95 miles (153 kilometers) northwest of Honolulu and having 627 square miles (1,624 square kilometers) of land area. The population of Kauai is 
small, only about 56,400 in 1996 . Even though some of the plantations on the island of Kauai are the highest yielding in the State, the amount of land planted in sugarcane in 1994 was 34\% lower than in 1969. The island is divided into five districts: Hanalei, Kawaihau, Lihue, Koloa, and Waimea. A map of Kauai, showing those districts, is presented in Figure 2-2.

\subsection{Energy Problems and Regulations that Could Impact Ethanol Production in Hawaii}

Hawaii's unique characteristics, being remote from continental masses and consisting of young volcanic islands, give rise to specific problems relating to energy supply and security. Hawaii depends on imported oil for about $90 \%$ of its energy, more than any other state in the nation (State of Hawaii, 1995). About $40 \%$ of Hawaii's crude oil comes from Alaska and the rest from the Asia-Pacific (25\% from Indonesia, 15\% from China, 15\% from Australia, and $>3 \%$ from Malaysia and other countries). The projected decline of export capabilities of these sources will increase the uncertainty in Hawaii's energy supplies. Ethanol production in Hawaii can significantly reduce its transportation energy vulnerability.

Hawaii is also vulnerable to interruptions in emergency energy supplies. Disruption in imported oil and refined petroleum product to Hawaii would be devastating, as the State has limited reserve transportation fuels. The long distance from the U.S. Strategic Petroleum Reserve in Louisiana and Texas, combined with the declining number of U.S. tankers capable of transiting the Panama Canal, make timely emergency deliveries directly from the reserve problematical. An agriculture-based ethanol industry in Hawaii can increase the state's transportation fuel reserves; however, the cost of developing a biomass-toethanol industry in Hawaii could hamper energy security.

Results of previous studies all point to high ethanol production cost, ranging from $\$ 0.94$ per gallon to over $\$ 3.00$ per gallon (Shleser, 1994), as the primary barrier to widespread production and utilization of ethanol for transportation fueling. If the cost of producing ethanol could be reduced, the State of Hawaii would be an ideal location to produce, distribute, and use ethanol fuel.

Despite the aforementioned bottleneck, the State of Hawaii has adopted a proactive stance with regards to energy self-sufficiency. The State of Hawaii Energy Policy Statement, developed under the Hawaii Energy Strategy Program by the State's Energy Policy Advisory Committee, outlines the objective, principle, and policies of energy system development. Following are excerpts from the Hawaii Energy Policy Statement:

"Hawaii's energy objective is to ensure a dependable, efficient, and economical energy system capable of supporting Hawaii's energy needs, while increasing the state's energy self-sufficiency and energy security. This objective will be met through increased efficiency of energy use; increased diversification of Hawaii's energy sources; and the maintenance of a strong energy emergency preparedness program.”

"Hawaii's current overdependence upon petroleum is of major concern. Aggressive implementation of cost-effective energy efficiency measures and diversification of energy supplies shall be given priority consideration in reducing this overdependence and increasing energy security..."

"The state shall encourage the development of its renewable energy resources in a socially and environmentally sensitive and cost-effective manner. Renewable energy research, development, and demonstration activities will be prioritized to advance those resources which have high commercialization potential and high benefit/cost ratio. The incorporation of renewables and alternative fossil fuels shall be considered in determining a practical energy strategy..." 
"Liquid fuel requirements for transportation account for approximately two-thirds of the energy consumed in the state. In this regard, the state shall promote improved energy efficiency measures and alternative transportation systems which reduce petroleum consumption. Widespread adoption of alternate fuels for air and ground transportation will largely depend on research, development and commercialization activities which occur elsewhere. Therefore, the state shall ... position itself to take maximum advantage of breakthroughs in transportation energy conservation and alternate fuels as they occur..."

As seen in the State of Hawaii's Energy Policy Statement, the adoption of alternate fuels is a key component of the State's energy strategy. The transportation energy strategy, which was developed within the Hawaii Energy Strategy Program, considers ethanol as a leading alternative fuel to gasoline and diesel in the ground transportation sector (State of Hawaii, 1995). Moreover, interest in ethanol production and use in Hawaii has existed for a long time. Substantial subsidies and tax benefits for producing ethanol have been available since the enactment of the Energy Tax Act of 1978. Entities purchasing "clean fuel" dispensing equipment are eligible for income tax deductions. Actions by the Federal government also support alternate fuel use.

In 1992, Congress enacted the National Energy Policy Act (EPACT), with the intent of encouraging alternate fuel use by making fuels less costly and more available. Since 1996, EPACT required fleets having more than 20 centrally-fueled light duty vehicles located in metropolitan areas (in Hawaii, only Oahu is covered) to purchase alternate fuel vehicles (AFVs). From 2000-2006, 75\% of new vehicles purchased by the Federal government each year must be AFVs. For state governments, 50\% of new vehicles purchased in 2000 must be AFVs. This increases to $75 \%$ between 2001 and 2006. Twenty percent of new vehicles belonging to municipal governments and private fleets must be AFVs in 2002. This doubles to 40\% in 2003, increases to $60 \%$ in 2004 , and levels off at $70 \%$ in 2006. There also are tax incentives for AFV purchases, conversions, and installation of "clean fuel" dispensing equipment. In addition to vehicle purchase requirements, there are reporting requirements, provisions for exemptions, and provisions for credits if an agency purchased more than the required number of vehicles or purchased AFVs in advance of the requirements. Each "covered fleet" is required to submit reports to the USDOE annually. Failure to acquire vehicles or file reports as required could result in prosecution under Federal law.

\subsection{Previous Experiences with Alternate Fuels in Hawaii}

Various research and demonstration activities involving alternative ground transportation fuels have been conducted in Hawaii. In 1980, Pacific Resources, Inc. (owner of the former Hawaii Independent Refinery, Inc.) and C. Brewer and Company conducted feasibility studies on the production of ethanol from molasses. In 1985, an ethanol-from-molasses facility was constructed at Campbell Industrial Park on Oahu but ceased operating after a short period (Shleser, 1994).

Utilization of alternative fuels to gasoline and diesel has been successfully demonstrated in Hawaii numerous times in the past. The USDOE supported the Hawaii Alternative Fuels Utilization Program to stimulate the use of alternative ground transportation fuels in Hawaii, and more recently, in the demonstration of alternative fuel vehicles and educating the public on alternative fuels. Demonstration activities centered on the use of methanol in flexible fuel vehicles. The State of Hawaii's Department of Business, Economic Development, and Tourism (DBEDT) and the Hawaii Natural Energy Institute (HNEI) of the University of Hawaii launched the demonstration of seven M85 (85\% methanol, 15\% gasoline) vehicles in 1988. The program demonstrated that M85 is an acceptable blend for vehicles in Hawaii. A similar program, which began in 1993, demonstrated a fleet of flexible-fuel vehicles capable of operating on various blends of methanol and gasoline. Interest was expressed by many individuals and companies to participate in the demonstration activities, and the use of alternative fuels for transportation has been promoted in Hawaii (School of Ocean and Earth Science and Technology, 1996). 
The USDOE and the State of Hawaii also funded several studies to identify appropriate processes and feedstocks, and to determine the economic feasibility of producing energy crops and ethanol in Hawaii. For example, an "Investigation of Biomass for Energy Production on Molokai" was completed by HNEI in 1993, which provided valuable information on energy-crop production and selection (Hubbard and Kinoshita, 1993). A "Comparative Study of Biomass Yields for Tree and Grass Crops Grown for Conversion to Energy" was completed by the Hawaiian Sugar Planters' Association (HSPA) in 1993 (Osgood and Dudley, 1993), which has been widely referred to for energy-crop selection. A project entitled "Ethanol Production in Hawaii - Feedstocks, Processes, and Current Economic Feasibility of Fuel-grade Ethanol Production in Hawaii," completed in 1994 with funding from the USDOE (Shleser, 1994), reviewed the potential for growing crops specifically for ethanol production. The "Sustainable Biomass Energy Program" was developed by the Pacific International Center for High Technology Research (PICHTR) to evaluate the potential for producing energy crops to displace sugarcane following the closing of sugar operations in the state (Pacific International Center for High Technology Research, 1994). Data from these earlier efforts have provided the bases for follow-on evaluations of the potential for biomass-to-ethanol production in Hawaii and were used in this investigation. 


\section{Candidate Ethanol-Crop Selection}

\subsection{Criteria for Crop Selection}

Selecting the best crop species for ethanol production must consider various factors: suitability to local conditions; yield of biomass per harvest and the number of years required to produce a harvestable crop; cost of cultivating, harvesting, and transporting the crop to an ethanol conversion facility; and suitability of the crop for conversion to ethanol. Yield potential is a critical factor that impacts the economic feasibility of biomass-for-ethanol production and is location dependent. Because selecting the best crop is site specific, several candidate crops first were identified and then were investigated further for specific sites. To avoid having to extrapolate from small scale plantings or speculate too extensively on yield, this analysis focused only on crops that had production histories or had undergone large-scale experimentation and demonstration in Hawaii.

\subsection{Selection of Candidate Crops}

To date, various tree and grass species have been considered and tested for short-rotation, intensiveculture energy cropping. Most of those species have the potential to be refined into energy, fiber, or chemical products, such as ethanol. Among the species investigated, Leucaena and Eucalyptus show the strongest commercial potential of the tree species, owing to their high yields and adaptability. Banagrass (Pennisetum purpureum) has been identified to have the highest yield potential of the grass species (Kinoshita and Staackmann, 1994). Sugarcane, the major crop grown in Hawaii, and referred to as 'energy cane' by some researchers (e.g., Alexander, 1985) because of its high yields of fiber and fermentable sugars is another energy-crop candidate. Sweet sorghum also is a potential candidate for ethanol production (Shleser, 1994), but has not been studied extensively as an energy crop and therefore was dropped from consideration.

\subsubsection{Tree Crops}

Experimental plantings of potential tree crops were installed at five sites on four Hawaiian islands (Fig. 3-1) by HSPA (Osgood and Dudley, 1993).

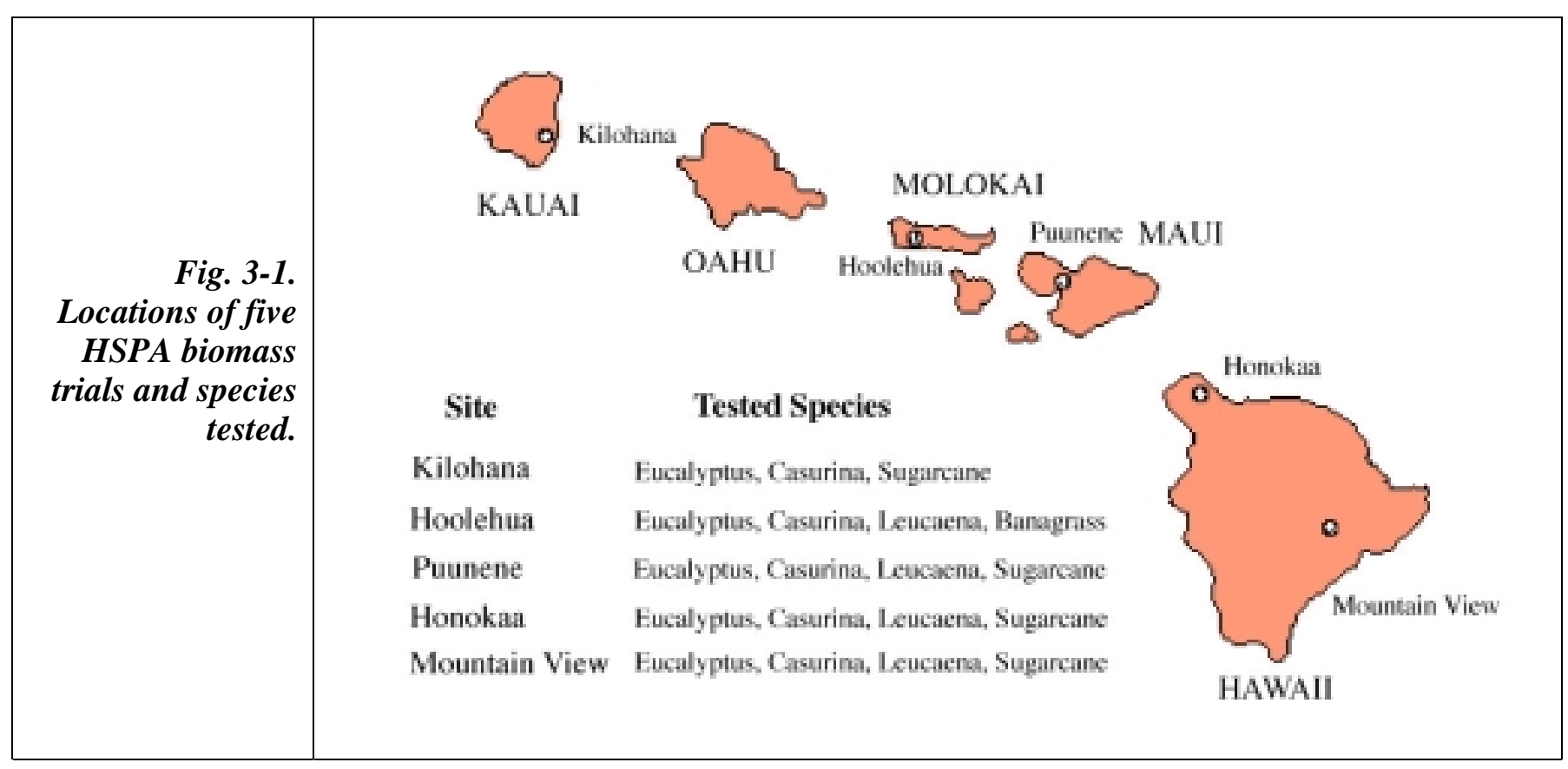


The locations have various types of agronomic conditions and represent a wide range of conditions, spanning essentially all potential lands for commercial ethanol-crop cultivation in Hawaii. The conditions at these sites are summarized in Table 3-1.

Table 3-1. Description of experimental biomass production sites. ${ }^{1}$

\begin{tabular}{|c|c|c|c|c|c|}
\hline$\underline{\text { Site/Island }}$ & Elevation & $\begin{array}{l}\text { Annual } \\
\text { Rainfall } \\
\end{array}$ & $\begin{array}{c}\text { Average } \\
\text { Temperature } \\
\end{array}$ & $\underline{\text { Insolation }}$ & $\begin{array}{l}\text { Agronomic } \\
\text { Conditions } \\
\end{array}$ \\
\hline & $(\mathrm{ft})$ & (inches) & $\left({ }^{\circ} \mathrm{F}\right)$ & (langleys) & \\
\hline Mountain View, Hawaii & 972 & 182 & 70 & 311 & wet, upland \\
\hline Honokaa, Hawaii & 762 & 81 & 70 & 390 & $\begin{array}{l}\text { moderately dry, } \\
\text { upland }\end{array}$ \\
\hline Puunene, Maui & 25 & 19 & 77 & 491 & $\begin{array}{l}\text { dry, irrigated, } \\
\text { lowland }\end{array}$ \\
\hline Kilohana, Kauai & 842 & 119 & 69 & 450 & $\begin{array}{l}\text { wet, intermediate } \\
\text { elevation }\end{array}$ \\
\hline Hoolehua, Molokai & 250 & 28 & 73 & 450 & $\begin{array}{l}\text { dry, irrigated, } \\
\text { intermediate } \\
\text { elevation }\end{array}$ \\
\hline 1. Osgood and Dudley ( & 93). & & & & \\
\hline
\end{tabular}

Two types of experiments were installed at each site, small plot trials (comparisons of promising tree species grown at $1 \times 1 \mathrm{~m}(3.28 \times 3.28 \mathrm{ft})$ spacing), and a large plot replicated demonstration (trees planted at $2 \times 2 \mathrm{~m}(6.56 \times 6.56 \mathrm{ft})$, commercial spacing). For comparison, a grass biomass plot was installed at each site. The experimental results from large plots, which mimic commercial practice, are used in this investigation.

Tree diameters were measured in each plot, 24, 36, 48, 60 months after planting. At the 60-months harvest, 20 randomly selected trees per species were felled and measured. The measured diameters indicated that Eucalyptus produced the greatest diameter growth at the Hamakua site; Leucaena produced comparable diameter growth at the low elevation, Puunene and Hoolehua sites. The biomass yields of Eucalyptus and Leucaena trees at the 60-months harvest are presented in Table 3.2. Casurina equisetifolia did not perform as well as the other two species and therefore was dropped from consideration.

The data in Table 3-2 indicate relatively high productivity by Eucalyptus in higher elevations and Leucaena leucocephala (K636) in lower elevations. Averaged over all sites, trees had a dry matter yield of 9.2 tons per acre-year. The highest annual yield for a tree crop was 14.2 tons per acre-year for E. urophylla at the Honokaa site. The small-plot and large-plot trials indicated that Eucalyptus has relatively high yield potential in high rainfall, high elevation locations, and Leucaena is better adapted to lowland, low rainfall areas.

Commercial planting of Eucalyptus resumed recently in Hawaii. In 1997, Forest Solutions Inc., began planting Eucalyptus trees along the Hamakua and North Hilo coasts of Hawaii island. Total planned forest land is about 18,000 acres, with about 6,000 acres being planted annually (Thain, 1998). Figure 3-2 shows 1.5 months old seeded Eucalyptus and 15 months transplanted Eucalyptus trees. The diameter of 15months trees is about 3 inches; the growth rate depends on the quality of land. Although the objective of the 
Forest Solutions plantation is to produce woodchips from tree logs, experience from this plantation would be helpful in planning ethanol-crop-production in Hawaii.

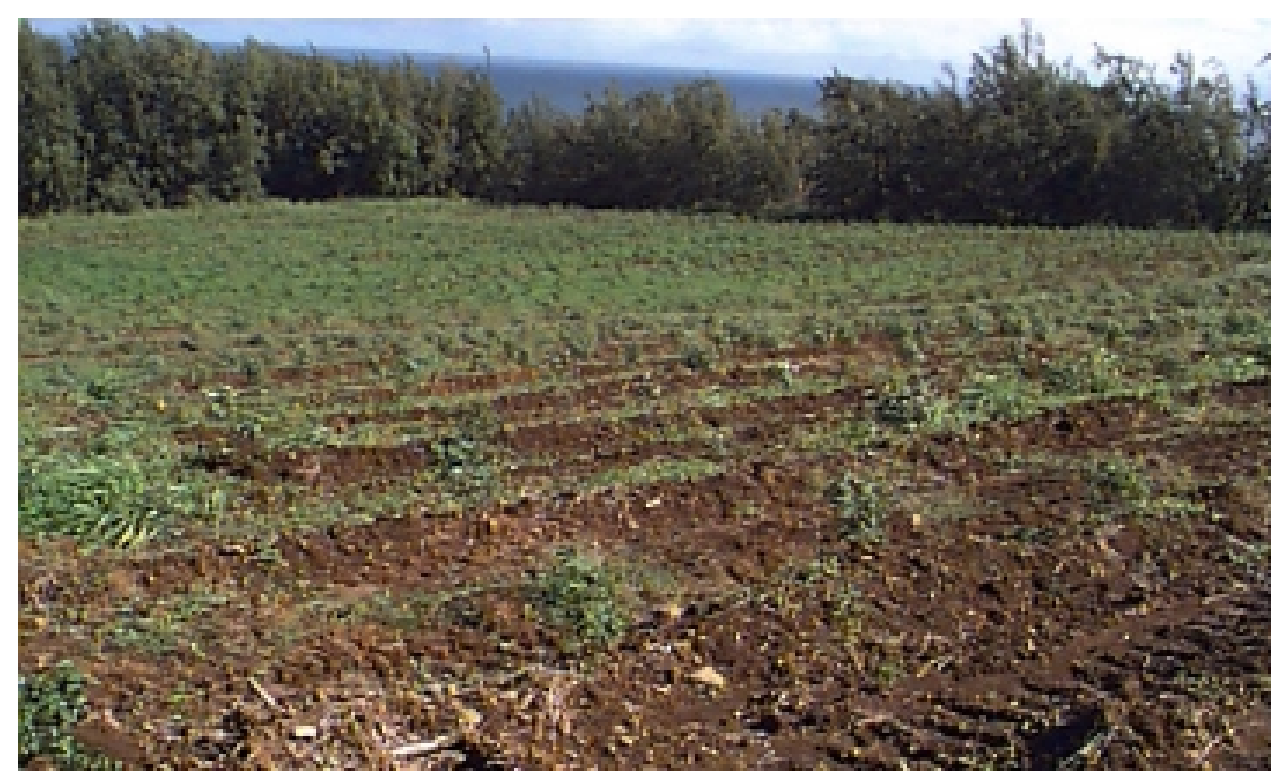

(a) 1.5 months after planting.

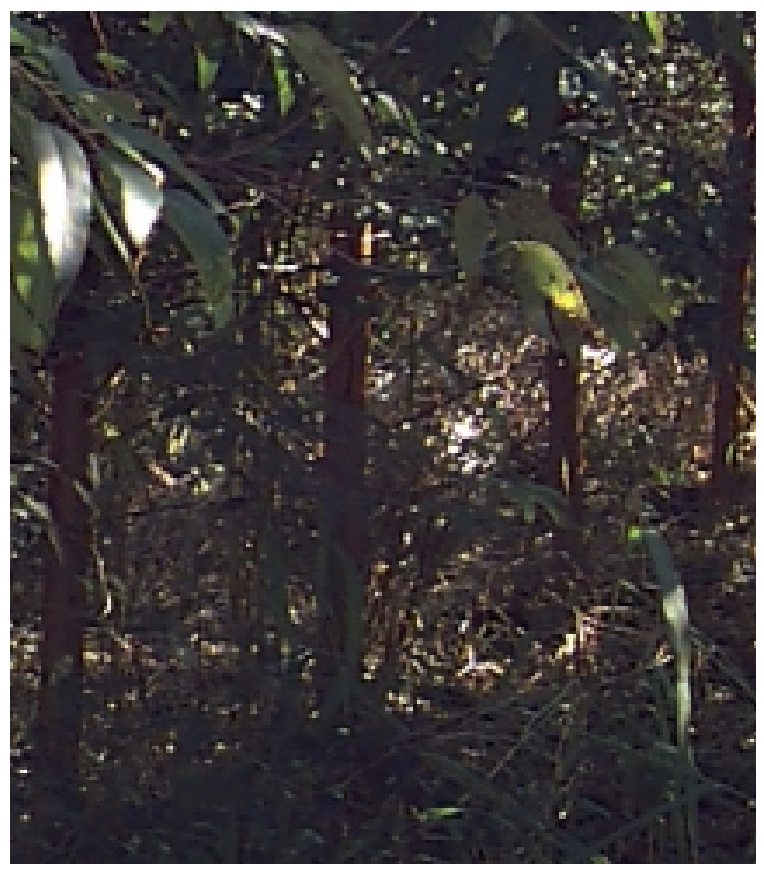

(b) 15 months after planting.

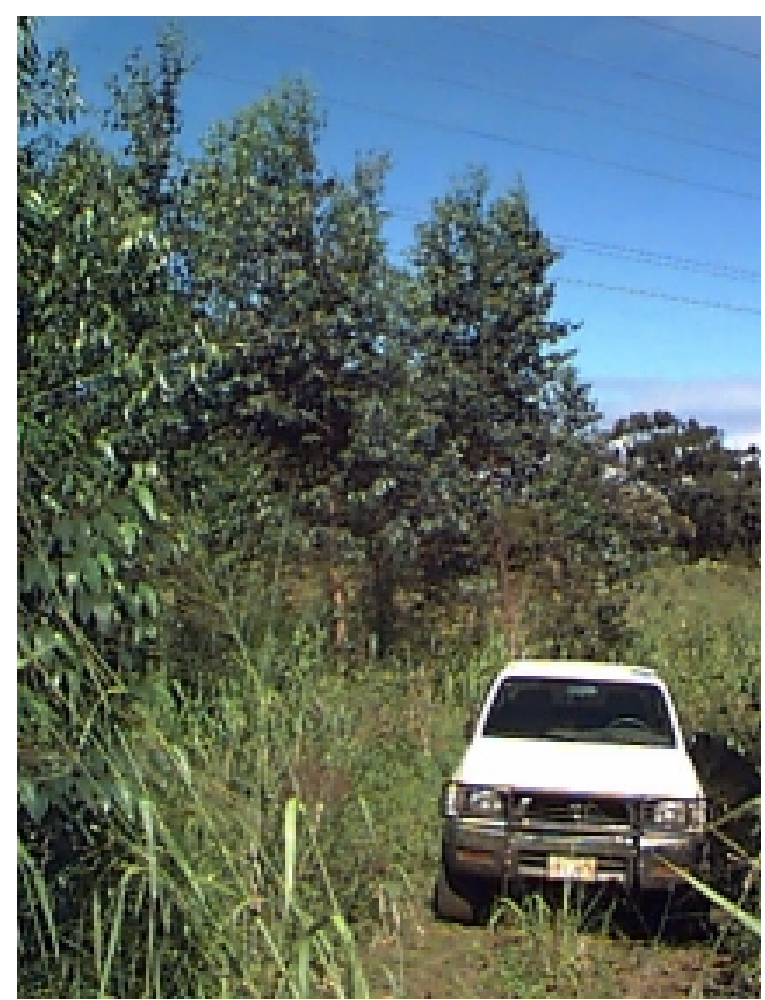

(c) 18 months after planting.

Fig. 3-2. Eucalyptus forest plantation sites on Hamakua, Hawaii Island. 
Table 3-2. Tree biomass yields at five Hawaiian sites after five years. ${ }^{1}$

\begin{tabular}{|c|c|c|c|c|}
\hline$\underline{\text { Site/Island }}$ & $\underline{\text { Tree Species }}$ & $\begin{array}{c}\text { Planted } \\
\text { Density } \\
\text { (trees/acre) }\end{array}$ & $\begin{array}{c}\text { Total } \\
\text { Yield } \\
\text { (tons/acre) }\end{array}$ & $\begin{array}{c}\begin{array}{c}\text { Annual } \\
\text { Yield }\end{array} \\
\text { (tons/acre-year) }\end{array}$ \\
\hline \multirow[t]{3}{*}{ Mountain View, Hawaii } & E. grandis & 1,012 & 45.2 & 9.0 \\
\hline & E. saligna & 1,012 & 25.0 & 5.0 \\
\hline & E. urophylla & 1,012 & 45.0 & 9.0 \\
\hline \multirow[t]{3}{*}{ Honokaa, Hawaii } & E. grandis & 1,012 & 65.0 & 13.0 \\
\hline & E. saligna & 1,012 & 45.9 & 9.2 \\
\hline & E. urophylla & 1,012 & 70.9 & 14.2 \\
\hline \multirow[t]{2}{*}{ Puunene, Maui } & E. grandis & 1,212 & 37.1 & 7.4 \\
\hline & L. leucocephala (K636) & 1,212 & 53.5 & 10.7 \\
\hline \multirow[t]{2}{*}{ Kilohana, Kauai } & E. grandis & 1,012 & 36.4 & 7.3 \\
\hline & E. urophylla & 1,012 & 39.1 & 7.8 \\
\hline \multirow[t]{2}{*}{ Hoolehua, Molokai } & E. calmaldulensis & 1,012 & 38.5 & 4.4 \\
\hline & L. leucocephala (K636) & 1,012 & 47.9 & 9.6 \\
\hline
\end{tabular}

\subsubsection{Grass Crops}

\section{Sugarcane}

Sugarcane is one of the most promising grass crops for ethanol production, and has advantages over most other energy-crop candidates, including well developed cultivation and harvesting practices and infrastructure. Owing to the more than century-long experience in growing sugarcane commercially in Hawaii, its high yield and yield potential, the existing support infrastructure, and its inherent advantages in conversion to ethanol, sugarcane is one of the energy-crop candidates considered in this investigation.

\section{Banagrass}

Experimental plantings of banagrass, a variety of Elephantgrass, were installed throughout the State by HSPA (Tew, 1989) and in a ten-acre energy-grass demonstration on Molokai by HSPA and HNEI. The experimental plantings were installed at five sites on four Hawaiian islands. The sites have various types of agronomic conditions spanning virtually all lands available for commercial energy-crop production. Most of these sites are located on former or current sugar lands and the yields of banagrass are comparable to or greater than sugarcane yields at the same location. Table 3-3 summarizes the conditions of the five experimental sites.

In the banagrass yield trials, the average yield for the banagrass plant (seeded) crops was 18.5 tons per acre-year (dry basis), while the ratoon (the regrowth after harvesting) crops averaged 42.1 tons per acreyear (Table 3-4). The fiber contents in the ratoon crops and the plant crops were significantly different fiber content in the ratoon crops averaged $29.6 \%$, while plant crops averaged only $18.9 \%$ fiber. 
Another experimental planting of banagrass was installed at Hoolehua, Molokai. Seven crops of banagrass, one plant crop and six ratoon crops, were harvested from a test plot over a 4.3 year period, spanning 1987 to 1991. Yield results are presented in Table 3-5. The average dry-matter yield over the seven crops was 19.5 tons per acre-year. The results show that crops grown during the summer have much higher yields than crops grown during the winter.

The most notable banagrass trial performed in Hawaii was a ten-acre demonstration managed by HNEI and HSPA (Fig. 3-3). The objective of this demonstration, located at the U.S. Department of Agriculture's Plant Materials Center in Hoolehua, Molokai (the same location of 0.7 acre test plot), was to validate the biomass yield figures obtained previously in the small plot tests and to simulate energy-crop production at scales closer to commercial operations. Two crop cycles of banagrass were grown in this demonstration.

Table 3-3. Description of experimental banagrass production sites. ${ }^{1}$

\section{$\underline{\text { Site/Island }}$}

Mauna Kea Agribusiness Co., Hawaii

$\mathrm{HC} \& S, \mathrm{Maui}^{2}$

McBryde Sugar Co., Kauai

The Lihue Plantation Co., Kauai

Waialua Sugar Co., Oahu

1. Data from Tew (1989).

2. Hawaiian Commercial \& Sugar Co. (HC\&S).
Annual Avg. Max.

$\underline{\text { Elevation }}$

(ft)

500

305

700

360

700 (in)

$\left({ }^{\circ} \mathrm{F}\right)$

75

84

77

77

78
Irrigation

$\underline{\text { Insolation } \text { Conditions }}$

(langleys)

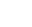


Twelve plots of banagrass (each plot comprising two rows, 20 feet long) were hand-harvested at 7.7 month of age and weighed; samples of banagrass were collected and analyzed to determine dry-matter yield and other properties. Approximately one month after the plot harvests were taken, the entire 10-acre planted crop was harvested using commercial sugarcane harvesting and transporting equipment.

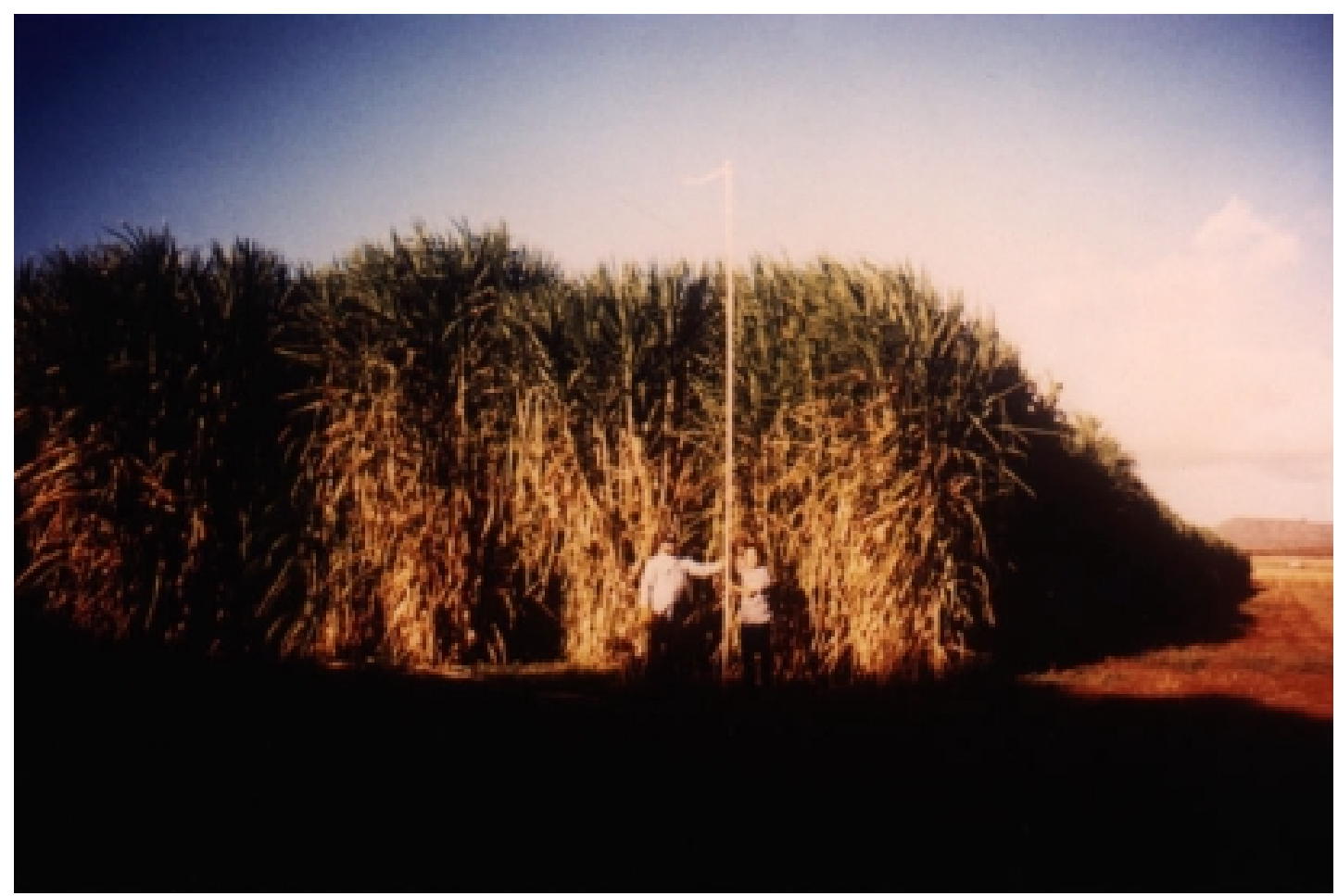

Fig. 3-3. Ten-acre banagrass demonstration at USDA Plant Materials Center, Molokai.

Table 3-5. Banagrass yields (dry matter) in 0.7 acre test plot at Hoolehua, Molokai.

\begin{tabular}{|cccccc|}
\hline Harvest Number & Harvest Date & Crop Days & $\begin{array}{c}\text { Yield } \\
\text { (tons/acre) }\end{array}$ & $\begin{array}{c}\text { Dry Matter } \\
\text { (tons/acre-year) }\end{array}$ & $\underline{\text { Season }}$ \\
1 & $4 / 20 / 1987$ & 217 & 6.87 & 11.55 & Winter \\
2 & $11 / 8 / 1987$ & 212 & 15.80 & 27.21 & Summer \\
3 & $5 / 24 / 1988$ & 188 & 9.69 & 18.81 & Winter \\
4 & $2 / 22 / 1989$ & 289 & 15.83 & 20.35 & Winter \\
5 & $8 / 23 / 1989$ & 176 & 15.10 & 31.32 & Summer \\
6 & $4 / 3 / 1990$ & 223 & 8.87 & 14.51 & Winter \\
7 & $1 / 8 / 1991$ & 280 & 11.61 & 15.13 & Winter \\
Average & & 226 & 13.62 & 19.84 & \\
1. Plots of 40 feet x 40 feet (12 meters x 12 meters) were hand harvested. Three \\
replications were harvested on each date from the 0.7 acre planting.
\end{tabular}

After the planted crop was harvested, the drip tubing was replaced and irrigation was resumed. Nitrogen and potassium were applied monthly for the first six months of the ratoon crop. As with the planted crop, 12 plots were hand-harvested at 8.0 months to determine the ratoon-crop yield. 
The yield results for the planted and ratoon crops from this large trial are presented in Table 3-6. The average dry-matter yield for the planted crop was 16.7 tons per acre at 7.7 months, translating to an annualized dry-matter yield of 26.1 tons per acre-year. The ratoon crop produced an average dry-matter yield of 19.9 tons per acre at 8.0 months, equal to an annualized dry-matter yield of 30.1 tons per acre-year.

Table 3-6. Results of ten-acre banagrass production trial on Molokai. ${ }^{1}$

\begin{tabular}{|c|c|c|c|c|c|}
\hline \multirow[t]{2}{*}{$\underline{\text { Block }}$} & \multirow[t]{2}{*}{$\underline{\text { Plot }}$} & \multicolumn{2}{|c|}{ Yield - Planted Crop } & \multicolumn{2}{|c|}{ Yield - Ratoon Crop } \\
\hline & & (tons/acre) & (tons/acre-year) & (tons/acre) & (tons/acre-year) \\
\hline \multirow[t]{3}{*}{1} & 1 & 10.9 & 17.1 & 12.2 & 18.3 \\
\hline & 2 & 18.2 & 28.5 & 13.4 & 20.1 \\
\hline & 3 & 15.2 & 23.8 & 14.8 & 22.3 \\
\hline \multirow[t]{3}{*}{2} & 1 & 16.2 & 25.4 & 19.2 & 28.7 \\
\hline & 2 & 10.2 & 16.0 & 17.7 & 26.6 \\
\hline & 3 & 13.1 & 20.4 & 17.0 & 25.5 \\
\hline \multirow[t]{3}{*}{3} & 1 & 22.6 & 35.4 & 23.5 & 35.2 \\
\hline & 2 & 17.3 & 27.1 & 27.6 & 41.3 \\
\hline & 3 & 11.9 & 18.6 & 20.6 & 30.8 \\
\hline \multirow[t]{3}{*}{4} & 1 & 24.3 & 38.0 & 28.2 & 42.3 \\
\hline & 2 & 19.7 & 30.8 & 22.4 & 33.6 \\
\hline & 3 & 20.6 & 32.2 & 24.1 & 36.1 \\
\hline \multicolumn{4}{|l|}{$\underline{\text { Summary }}$} & $\underline{\text { Planted Crop }}$ & $\underline{\text { Ratoon Crop }}$ \\
\hline \multicolumn{4}{|c|}{ Age at harvest (months) } & 7.7 & 8.0 \\
\hline \multicolumn{4}{|c|}{ Moisture content (\%) } & 71.6 & 64.2 \\
\hline \multicolumn{4}{|c|}{ Crop yield, fresh (tons/acre) } & 58.0 & 55.8 \\
\hline \multicolumn{4}{|c|}{ Annualized yield, fresh (tons/acre-year) } & 91.0 & 83.9 \\
\hline \multicolumn{4}{|c|}{ Crop yield, dry (tons/acre) } & 16.7 & 19.9 \\
\hline \multicolumn{4}{|c|}{ Annualized yield, dry (tons/acre-year) } & 26.1 & 30.1 \\
\hline
\end{tabular}

The series of trials described above indicate that: (1) with proper management, banagrass yields exceeding 20 tons per acre-year appear feasible on a sustained basis; (2) banagrass ratoon crops normally attain higher yields than plant crops; (3) multiple ratoon crops can be obtained from a single plant crop without undergoing substantial decline in yield.

\subsection{Projections of Commercially Achievable Yields of Candidate Crops}

The yield of a crop is highly dependent on agronomic conditions (insolation, water, nutrients, etc.) at the site. The yields reported here are projected from previous production or experimental results. 
Calculations performed previously (Kinoshita, 1984) suggest that sugarcane grown commercially in Hawaii during the late 1970s and early 1980s produced an average dry-matter yield (prior to burning the crop in the field in preparation for harvesting and processing) of 17.5 tons per acre-year, comprising $\sim 60 \%$ fiber and $\sim 40 \%$ sugar.

The commercial yield of banagrass used in this investigation is based on the aforementioned yield trials performed by HSPA and HNEI and on the commercial yield of sugarcane in Hawaii. Based on the available information, it appears feasible to achieve commercial yields of 18 to 25 tons per acre-year (dry basis) of banagrass if inputs (water and nutrients) are not limiting factors. Because management plays a major role in the actual yields in any energy-crop operation, it is likely that if an aggressive breeding and selection program were pursued, higher commercial yields of banagrass than those assumed in this investigation could be achieved. The commercial banagrass yields estimated for the sites finally selected in the present investigation are, for irrigated fields, 22 tons per acre-year; for unirrigated fields, 18 tons per acre-year.

The tree yields can be estimated based on experimental plantations in Hawaii and projections by many other investigators. Whitesell et al. (1992) projected Eucalyptus yields of 8-12 tons per acre-year for unirrigated lands, and Phillips and co workers (1993) projected harvestable yields averaging 10.2 tons per acre-year. It appears feasible to obtain an average yield of 10 tons per acre-year for tree species in the Hawaiian islands. Eucalyptus has relatively high yield potential in high rainfall, high elevation locations; Leucaena is better adapted to lowland, low rainfall sites.

Projected crop yields and required land sizes are summarized in Table 3-7. The land size for each crop site is determined from the anticipated yields of the candidate species and the targeted crop production rates. The land required to meet the targeted crop production of this investigation, $300-1,000$ tons per day (dry basis), requires 4,000 to 30,000 acres of crop land, depending on the type of crop grown (Table 3-7).

Table 3-7. Anticipated dry matter yields of candidate crops and required acreage.

\begin{tabular}{|c|c|c|c|}
\hline$\underline{\text { Crops }}$ & $\frac{\text { Achievable yield }}{\text { (tons/acre-year) }}$ & $\frac{\text { Target Production }}{\text { (tons/day) }}$ & $\frac{\text { Required Land Size }}{\text { (acre) }}$ \\
\hline Sugarcane (irrigated) & 18 & $300-1,000$ & $5,000-16,700$ \\
\hline Banagrass (irrigated) & 22 & $300-1,000$ & $4,100-13,600$ \\
\hline Banagrass (unirrigated) & 18 & $300-1,000$ & $5,000-16,700$ \\
\hline Trees & 10 & $300-1,000$ & $9,000-30,000$ \\
\hline
\end{tabular}

It is necessary to point out that the yields of banagrass and tree species reported above were achieved with little optimization of production strategies such as breeding and selection for local conditions. It is likely that higher commercial yields than those estimated in this investigation could be achieved with aggressive breeding and selection. Inherent to higher yield projections is the assumption that inputs to crop production are not limiting factors.

\subsection{Ethanol Yield Potential of Candidate Crops}

The potential yield of ethanol from a particular biomass species depends on its composition, including simple sugars, cellulose, hemicellulose, and lignin. The percentages of these constituents in the 
candidate crops are presented in the Table 3-8. Sugarcane contains a high percentage of simple sugars; the other crops contain almost no sugar. The fraction of cellulose in the tree crops is greater than in the herbaceous crops. These constituents have different ethanol conversion yields. The ethanol yield per unit feedstock for each candidate crop, shown in Table 3-8, indicates that sugarcane has the largest ethanol yield potential per unit of dry matter, while the other candidate crops, banagrass and tree species, are likely to produce about same amount of ethanol per unit of dry matter. However, yield potential of ethanol per acre per year is highly dependent on biomass yield. The ethanol yield potential of banagrass per acre per year is much higher than that of tree species due to banagrass' higher biomass yield.

Table 3-8. Ethanol yield projections for candidate crop species.

\section{$\underline{\text { Sugarcane }}$ Banagrass Leucaena Eucalyptus}

Biomass yield (tons/acre-year, dry basis)

18

22

10

10

Ethanol yield (lb/lb dry biomass) ${ }^{2}$

0.40

0.26

0.29

0.26

Ethanol yield (gal/lb dry biomass)

0.06

0.04

0.04

0.04

Ethanol Yield Potential (gal/acre-year)

2,188

1,739

881

790

1. Wiselogel (1998).

2. Pacific International Center for High Technology Research (1994).

3. Weight of one gallon ethanol is $6.58 \mathrm{lb}$. 


\section{Land Availability Analysis}

Initial screening of potential sites for ethanol-crop production is based on the land availability, i.e., the relative accessibility to a parcel of land base on legal (e.g., zoning and ownership) and economic (e.g., present land use versus alternative land uses) factors. Limited land resources in this state creates conflict over land use and impacts land rent. The availability of land for ethanol-crop production in the State of Hawaii is dictated first by zoning because land use is constrained by laws and administrative rules. A statewide system of zoning designations has been in place since the 1960s; ethanol-crop plantation site selection has to follow those zoning designations. Additionally, in recent years, agriculture has been facing much difficulty in the state, with sugarcane production declining significantly during the last decade. Present and historic uses of a site are important factors in determining whether the land might be readily available for ethanol-crop production or any potential barriers exist that would prevent its use for such purposes; therefore, land use is considered in the availability analysis.

\subsection{Land Zoning}

Land use in the State of Hawaii has to follow strict guidelines, e.g., The State Land Use Law, enacted in 1961. Hawaii is the only state in the nation with statewide land-use designations, including Conservation, Agricultural, Urban, or Rural, as determined by the Land Use Commission. Fig. 4-1 presents maps of the four major islands, showing districts designated Agricultural and other.

Fig. 4-1. Land use districts on four major islands.

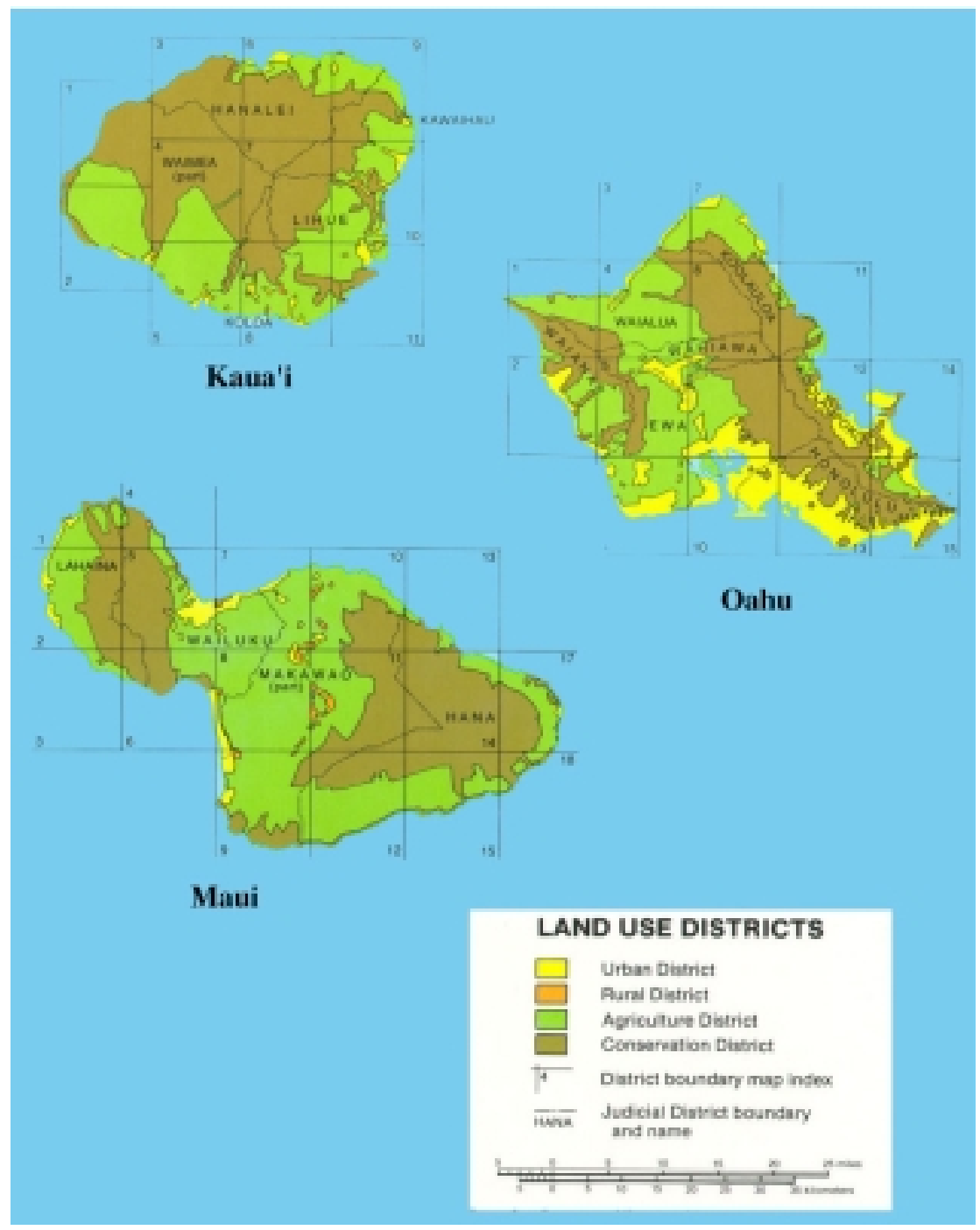




\section{Fig. 4-1 \\ (continued). Land use districts on four major islands.}

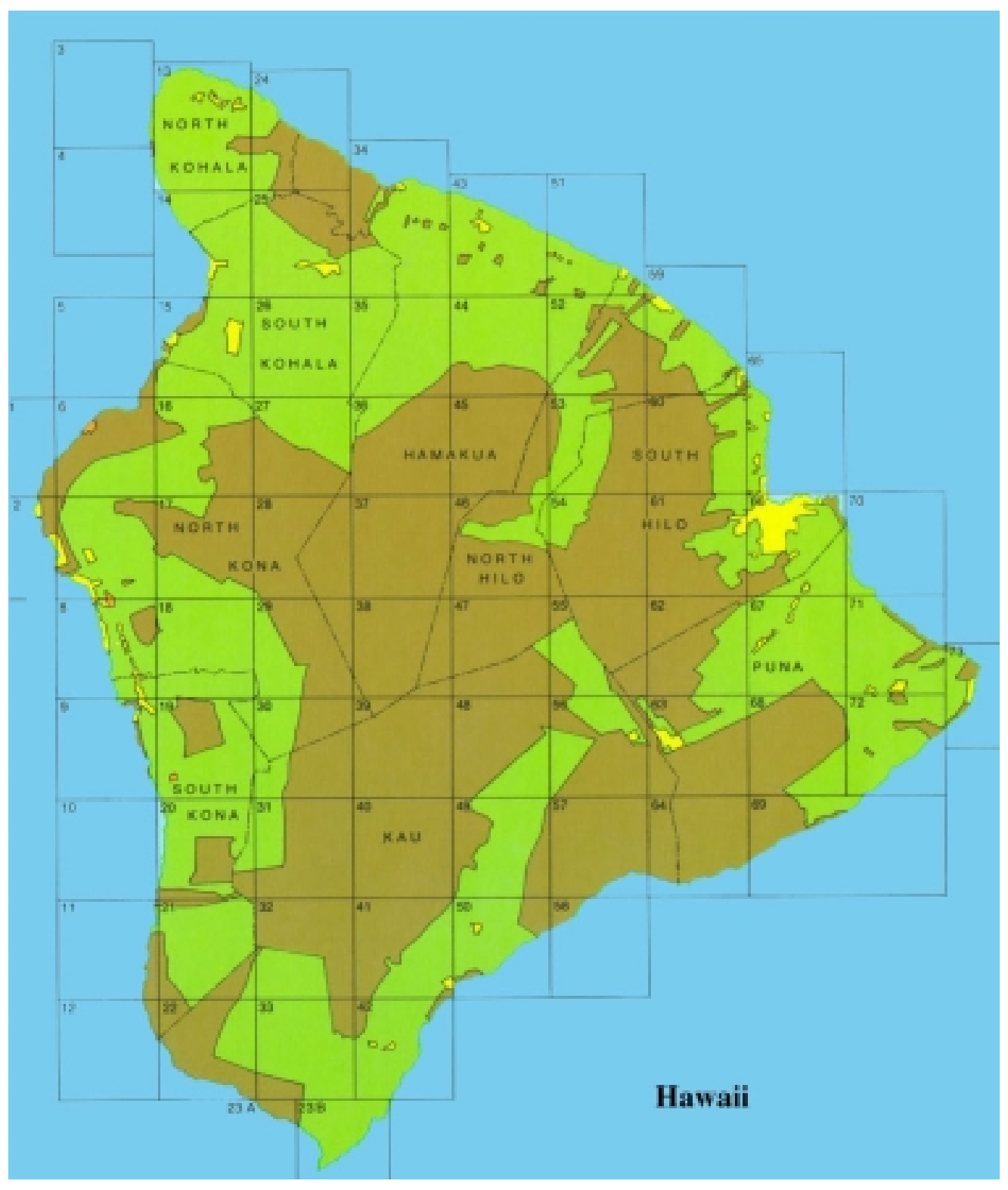

Generally, all lands zoned Urban and Rural are considered unavailable for energy-crop production and are eliminated from consideration. Most of the lands in Conservation Districts were classified as Probably Available and lands in Agricultural Districts, as Available by Philips et al. (1992). In the present analysis, candidate sites are only those located in districts designated Agricultural.

The acreages within each designation in the state and on the four major islands are presented in Table 4-1. Oahu island has about 130,000 acres (52,600 hectares) zoned Agricultural. Most of the agricultural lands on Oahu are located in the districts of Ewa, Wahiawa, and Waialua. The island of Hawaii, with about 1,200,000 acres (486,000 hectares) of Agricultural land, has nearly twice as much land zoned Agricultural as the remainder of the state. Maui island has the second largest acreage zoned Agricultural, about 250,000 acres (101,000 hectares). The Agricultural land on Kauai totals about 140,000 acres (56,600 hectares). 


\subsection{Land Use}

Because this investigation concerns energy crops, only those lands that are suitable for that use (i.e., for intensively cultivated crops) are considered. The primary agricultural uses of lands on the four major islands were evaluated to determine the availability of lands for ethanol-crop production.

\subsubsection{Oahu}

Housing the city of Honolulu, a large portion of the land on Oahu is under urban development. Agriculture, nevertheless, still is an important economic activity on the island. In 1995, the major agricultural land uses on Oahu, summarized in Table 4-2, fell into the following categories: sugar, pineapple, and diversified agriculture (which includes flowers and vegetables). Acreages for crops harvested on Oahu during 1991 to 1996 are presented in Table 4-3.

The data in Tables 4-2 and 4-3 show that sugarcane and pineapple used to be the major agricultural crops, occupying a large fraction of the agricultural lands on Oahu. But all sugarcane plantations have ceased operating on the island, leaving the former sugarcane lands available for other agricultural uses.

Table 4-1. Land use zoning in the State and on the four major islands.

\begin{tabular}{|c|c|c|c|c|c|c|}
\hline$\underline{\text { Island }}$ & $\underline{\text { District }}$ & Total & $\underline{\text { Urban }}$ & $\frac{\underline{\text { Rural }}}{\text { (acres) }}$ & Agricultural & $\underline{\text { Conservation }}$ \\
\hline \multicolumn{2}{|c|}{ State of Hawaii } & $4,112,388$ & 191,941 & 9,927 & $1,935,526$ & $1,974,994$ \\
\hline \multicolumn{2}{|l|}{ Oahu $^{1}$} & 386,188 & 98,221 & & 131,349 & 156,618 \\
\hline \multirow[t]{10}{*}{ Hawaii ${ }^{2}$} & Total & $2,533,401$ & 66,848 & 696 & $1,175,629$ & $1,290,228$ \\
\hline & Puna & 318,611 & 6,040 & 135 & 173,854 & 138,582 \\
\hline & South Hilo & 251,070 & 13,297 & 1 & 70,555 & 167,217 \\
\hline & North Hilo & 173,731 & 536 & 45 & 61,176 & 111,974 \\
\hline & Hamakua & 399,869 & 1,014 & - & 163,552 & 235,302 \\
\hline & North Kohala & 79,787 & 2,361 & 15 & 63,338 & 14,074 \\
\hline & South Kohala & 176,406 & 23,746 & - & 137,502 & 15,158 \\
\hline & North Kona & 365,165 & 14,323 & 468 & 168,310 & 182,063 \\
\hline & South Kona & 143,692 & 753 & 31 & 113,116 & 29,792 \\
\hline & $\mathrm{Kau}$ & 625,070 & 4,778 & - & 224,225 & 396,067 \\
\hline \multirow[t]{5}{*}{ Maui $^{3}$} & Total & 465,800 & 20,640 & 3,759 & 247,770 & 193,631 \\
\hline & Lahaina & 62,652 & 5,012 & - & 30,024 & 27,617 \\
\hline & Wailuku & 83,662 & 10,982 & 256 & 44,267 & 28,158 \\
\hline & Makawao & 204,688 & 4,096 & 3,249 & 131,496 & 65,847 \\
\hline & Hana & 114,798 & 111 & 236 & 44,489 & 69,962 \\
\hline \multicolumn{2}{|l|}{ Kauai $^{1}$} & 353,900 & 14,334 & 1,255 & 139,542 & 198,769 \\
\hline $\begin{array}{l}\text { 1. State } \\
\text { 2. Coun } \\
\text { 3. Coun }\end{array}$ & $\begin{array}{l}\text { Hawaii (1997). } \\
\text { f Hawaii (1997 } \\
\text { f Maui (1997, c }\end{array}$ & alculated us & Land U & Distric & Map). & \\
\hline
\end{tabular}


Sugarcane lands in the 1980s were located in only two districts, Ewa and Waialua (Fig. 4-2). As the major agriculture areas on the island, large fractions of lands in these two districts are zoned Agricultural (Fig. 4-1). Because Ewa and Waialua have many abandoned former sugarcane lands and large fractions of lands zoned Agricultural, these two districts are considered as the potential locations for ethanol-crop production sites on Oahu.

The amount of land available on Oahu is estimated from crop production data. As indicated in Table 4-3, sugarcane acreage on Oahu, 23,000 acres in 1991, declined dramatically in 1995 with the ceasing of sugar operations on the island. Over the same period, pineapple acreage decreased slightly, dropping from 12,700 acres in 1991 to 10,700 acres in 1996. Land in diversified agriculture increased by about 5,000 acres between 1991 and 1996, displacing roughly one-fourth of the abandoned sugarcane land. If no additional major agricultural activity takes place on Oahu, about 23,000 acres of former sugarcane land would be available for ethanol-crop production. It is noted that even if abandoned sugarcane lands were included, the total amount of land in agriculture would be less than 40,000 acres, less than one-third of all lands zoned Agricultural (about 131,000 acres) on this island.

Table 4-2. Major agricultural uses for land on Oahu, 1995.1, 2

$\underline{\text { District }}$

Honolulu

Ewa

Waianae

Waialua/Wahiawa
Agricultural Usage, 1995

Bananas, dairy, flowers and nursery products, poultry, vegetables. Pineapples, sugar, bananas, flowers and nursery products, watercress, vegetables.

Dairy, flowers and nursery products, hogs, poultry, vegetables. Pineapple, sugar, cattle, flowers and nursery products, lotus root, vegetables.

Koolauloa/Koolaupoko Bananas, cattle, flowers and nursery products, guavas, papayas, taro, vegetables, watermelon.

1. Hawaii Agricultural Statistics Service (1996).

2. Hawaii Agricultural Statistics Service (1997).

Table 4-3. Acreage in crops on Oahu, 1991 to 1996. ${ }^{1}$

\begin{tabular}{|c|c|c|c|c|c|c|}
\hline CroplYear & \multicolumn{6}{|c|}{ (acres) } \\
\hline Sugarcane & 23,000 & 22,500 & 22,600 & 22,300 & 8,000 & 0 \\
\hline Pineapple & 12,700 & 12,100 & 11,100 & 11,500 & 11,300 & 10,700 \\
\hline Vegetables and melons (harvested) & 900 & 900 & 900 & 1,000 & 1,900 & 2,500 \\
\hline Other fruits & 700 & 500 & 600 & 500 & 500 & 800 \\
\hline All other crops & 700 & 600 & 600 & 800 & 800 & 4,100 \\
\hline
\end{tabular}




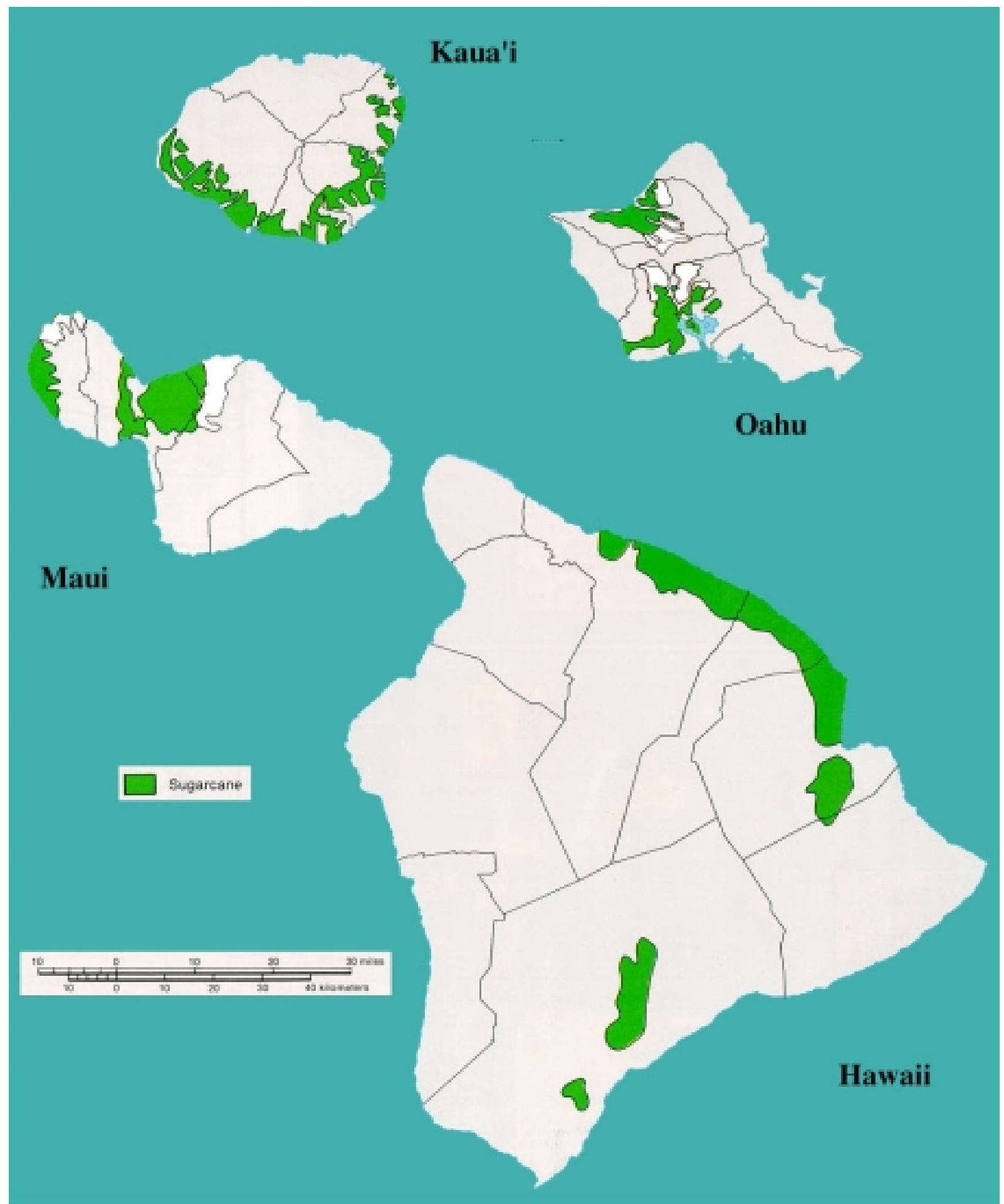

Fig. 4-2 Sugarcane lands on four Hawaiian islands in the 1980s.

Less than five years ago, two major sugarcane plantations were operating on Oahu (Table 4-4). Oahu Sugar Company, located in the Ewa district, farmed about 13,500 acres in 1988 (already significantly less than a decade earlier), and ceased operating in 1996. A second plantation, Waialua Sugar Company (WSCo), operated in the Waialua district. It spanned about 12,000 acres in 1988 and also ceased operating in 1996. The data show that each of those two districts has more than 12,000 acres of abandoned sugarcane land available for growing other crops. The two districts, Ewa and Waialua, are considered as two potential sites for ethanol-crop production on Oahu. 
Table 4-4. Recent commercial sugarcane operations on Oahu.

\begin{tabular}{|llcc|}
\hline Company & Location & \multicolumn{2}{c|}{ Cropland (acres) } \\
& & $1988^{1}$ & $1996^{2}$ \\
Oahu Sugar Co., Ltd. & Ewa & 13,561 & 0 \\
Waialua Sugar Co., Inc. & Waialua & 12,083 & 0 \\
Total & & 25,644 & 0 \\
1. Hawaiian Sugar Planters' Association (1989). & \\
2. Hawaiian Sugar Planters' Association (1997). & \\
\hline
\end{tabular}

\subsubsection{Hawaii}

Table 4-5 summarizes the acreage zoned Agricultural and the amount of land used for agriculture in 1992 in each district on Hawaii island. The data indicate that large quantities of lands in Hamakua, South Kohala and North Kona districts, totaling over 500,000 acres, are being used for agriculture. But South Kona, Ka' u, and Puna districts have large tracts of agricultural lands that are not being farmed; these lands could be used for ethanol-crop production.

Table 4-5. Agricultural land on Hawaii island: zoning and in use, July 1992.1

\begin{tabular}{|l|r|r|}
\hline District & \multicolumn{2}{|c|}{ Agricultural Land (acres) } \\
\hline Hawaii County & Zoned Argicultural & Used for Agriculture \\
\hline Puna & $1,175,629$ & 798,091 \\
\hline South Hilo & 173,854 & 18,581 \\
\hline North Hilo & 70,555 & 49,324 \\
\hline Hamakua & 61,176 & 78,081 \\
\hline North Kohala & 163,552 & 156,465 \\
\hline South Kohala & 63,338 & 49,824 \\
\hline North Kona & 137,502 & 140,108 \\
\hline South Kona & 168,310 & 203,829 \\
\hline Ka'u & 113,116 & 28,443 \\
\hline 1. County of Hawaii (1997). & 224,225 & 73,435 \\
\hline
\end{tabular}

The crop acreage on Hawaii island during 1991-1997 is summarized in Table 4-6. Sugarcane was the major crop on the island prior to 1996 , covering about 56,100 acres in 1991 . Other crops, including vegetables, melons, fruits, coffee, and other diversified crops, covered about 11,000 acres (pineapple is not grown on Hawaii island). Sugarcane production was abandoned on that island in 1996. Although lands used for crops other than sugarcane increased slightly, from 10,700 to 11,400 acres, over the period 1991 to 1996, it is unlikely that those crops will ever reach the scales of production that sugarcane owned prior to 1990. Recognizing that diversified agriculture will be able to occupy only a fraction of the abandoned sugarcane lands, the large tracts of fallow sugarcane lands offer much opportunity for large scale production of ethanol crops. 
Table 4-6. Acreage in commercial agriculture, Hawaii island, 1991 to 1997.1

\begin{tabular}{|c|c|c|c|c|c|c|c|}
\hline CroplYear & $\underline{1991}$ & $\underline{1992}$ & $\underline{1993}$ & $\frac{1994}{\text { (acres) }}$ & $\underline{1995}$ & $\underline{1996}^{2}$ & $\underline{1997}^{2}$ \\
\hline Sugarcane & 56,100 & 47,300 & 33,900 & 22,400 & 2,400 & 1,340 & - \\
\hline Other crops & 10,700 & 11,000 & 10,700 & 10,100 & 11,400 & no data & no data \\
\hline
\end{tabular}

Each district on Hawaii island is home to a distinct mix of diversified crops. Table 4-7 summarizes the agricultural land uses on the island. Three districts, Hamakua, North Hilo, and Ka'u, used to house major sugarcane plantations (Fig. 4-2). Hamakua and North Hilo are adjacent to each other and can be considered as a single area in site selection. Ka' $u$, located in the southern part of the island, is considered as a second site. Although other areas of this island have large tracts of land zoned Agricultural, the Hamakua/North Hilo and Ka'u regions have the greatest potential for production of energy crops because of the still existing cane-related infrastructure.

Table 4-7. Major agricultural use of land on Hawaii island, 1991.1

\begin{tabular}{|ll|}
\hline District & \multicolumn{1}{c|}{ Agricultural Uses, 1991 } \\
Puna & $\begin{array}{l}\text { Anthuriums, bananas, citrus, cucumbers, flowers/nursery products, guavas, } \\
\text { macadamia nuts, orchids, papayas, tomotoes. }\end{array}$ \\
$\begin{array}{l}\text { South Hilo } \\
\text { North Hilo }\end{array}$ & $\begin{array}{l}\text { Flowers/nursery products, guavas, macadamia nuts, poultry. } \\
\text { Sugattle/pasture, cucumbers, ginger root, macadamia nuts, taro. }\end{array}$ \\
Horth Kohala & $\begin{array}{l}\text { Sugar, cattle/pasture, cucumbers, ginger root, macadamia nuts, taro. } \\
\text { Cattle/pasture, dairy, flowers/nursery products, macadamia nuts, poultry, } \\
\text { sheep. }\end{array}$ \\
South Kohala & $\begin{array}{l}\text { Broccoli, burdock, chinese cabbage, cattle/pasture, cauliflower, celery, } \\
\text { daikon, dairy, head lettuce, romaine, roses. }\end{array}$ \\
North Kona & $\begin{array}{l}\text { Avocados, cattle/pasture, coffee, eggplant, flowers/nursery products, } \\
\text { macadamia nuts, poultry, tomatoes. }\end{array}$ \\
South Kona & $\begin{array}{l}\text { Avocados, cattle/pasture, coffee, eggplant, flowers/nursery products, } \\
\text { macadamia nuts, poultry, tomatoes. }\end{array}$ \\
Ka'u & Cattle/pasture, macadamia nuts, sugar, carnations, citrus, dairy. \\
1. Hawaii Agricultural Statistics Service (1992).
\end{tabular}

Approximately 225,000 acres in the Hamakua/North Hilo districts are zoned Agricultural. Only a fraction, 43,500 acres, was planted in sugarcane on three plantations in that area (Table 4-8). Most of the agricultural land in the area sits in range and pasture. Ka' $u$ has about 224,000 acres zoned Agricultural but former sugarcane lands in the district covered only about 12,600 acres (Table 4-8). Some lands in Ka'u are used as range and pasture. This district has about 150,800 acres of unused agricultural land. These fallow agricultural lands represent the greatest potential for energy-crop production, although they may be costly to develop for that purpose. The abandoned sugarcane land, 43,500 acres in Hamakua/North Hilo districts and 
12,600 acres in $\mathrm{Ka}$ ' $\mathrm{u}$ district, are considered to be the best candidates for ethanol-crop production on the island of Hawaii.

Many efforts were made to find alternative uses for well developed sugarcane lands as sugarcane production began to decline on the island. One significant effort is forestry (Dudley, 1998). Planting of Eucalyptus trees on former sugarcane lands has commenced on Hawaii island with the intent to produce woodchip or other commercial wood products. Plans call for 15,000 to 20,000 acres of Eucalyptus in Hamakua and North Hilo, occupying about one-half of the lands formerly in sugarcane. One-half of the former sugarcane land in Ka'u, about 5,000 acres, will be used for Eucalyptus production as well. As a result of the ongoing forestry activity, only about 20,000 in Hamakua/North Hilo districts and about 5,000 acres in Ka'u would be available for ethanol-crop production.

Because the amount of the land available in those districts exceeds the acreage needed for ethanol production and those districts have significant amounts of undeveloped lands zoned Agricultural, they are still suitable candidates for ethanol-crop production.

Table 4-8. Major sugarcane plantations on Hawaii island, 1991.1

\begin{tabular}{|l|r|r|r|}
\hline Company & Total Caneland & Final Year of Production & Location \\
\hline (acres) & & & \\
\hline Hamakua Sugar Co. & 27,837 & 1995 & Hamakua \\
\hline Mauna Kea Agribusiness Co. & 14,683 & 1995 & Hilo \\
\hline United Cane Planters' Coop & 987 & 1995 & Hilo \\
\hline Ka'u Agribusiness Co. & 12,559 & 1996 & Ka'u \\
\hline Total & 56,066 & & \\
\hline 1. County of Hawaii (1997). & & & \\
\hline 2. Hawaiian Sugar Planters' Association (1997). & & \\
\hline
\end{tabular}

\subsubsection{Maui}

Maui is a popular tourist destination and has experienced rapid expansion in portions of the island that support tourism. Agriculture remains quite healthy on that island - thus far, Maui has largely escaped the major contractions and closures in sugar and pineapple operations experienced on the other islands. The major agricultural uses of land on Maui include sugarcane, pineapple, and diversified agriculture (Table 49). Acreages of crops in Maui County from 1991 to 1995 are summarized in Table 4-10. The data in Tables 4-9 and 4-10 indicate that sugarcane and pineapple continue to be the major crops in Maui County and on Maui island. These two crops are grown primarily in three districts on Maui island, Lahaina, Wailuku, and Makawao (see Fig. 4-2). The Lahaina district represents a large agricultural region. Another large agricultural region is located in central Maui and on the western slope of Haleakala. This area, which spans two adjacent districts, Wailuku and Makawao, is considered as a single site for ethanol-crop production.

Table 4-11 summarizes the acreage in sugarcane and pineapple on Maui island from 1991 to 1997. The data indicate that sugarcane production was stable over that period, but pineapple acreage dropped from 15,700 acres to 8,200 acres. About 7,500 acres of pineapple lands have been abandoned and have not been planted in other crops. Acreage for crops other than sugarcane and pineapple decreased slightly over the same period. 
Table 4-9. Major agricultural use of land on Maui island, 1995. ${ }^{1}$
$\underline{\text { District }}$
Agricultural Uses, 1995
Lahaina Sugar, pineapple, coffee.
Wailuku Pineapple, sugar, cattle, flowers/nursery products, hogs, macadamia nuts.
Makawao Pineapple, sugar, cattle, sheep, vegetables,flowers/nursery products, hogs, macadamia nuts.
Hana Cattle, bananas, flowers/nursery products, macadamia nuts, taro.
1. Hawaii Agricultural Statistics Service (1996).

Table 4-10. Crop acreage in Maui County, 1991 to 1995.1

\begin{tabular}{|lrrrrrr|}
\hline CroplYear & $\underline{1991}$ & $\underline{1992}$ & $\underline{1993}$ & $\underline{1994}$ & $\underline{1995}$ \\
& & & & & \\
Sugares) & & & \\
Pineapple & 42,500 & 42,200 & 42,100 & 41,900 & 42,600 \\
Vegetables and melons (harvested) & 15,700 & 14,100 & 10,900 & 10,800 & 9,500 \\
All other crops & 2,700 & 2,600 & 2,600 & 2,600 & 2,000 \\
1. County of Maui (1997). & & 1,200 & 1,900 & 2,000 & 2,200 \\
\end{tabular}

There were two major sugarcane plantations and one pineapple company on Maui island in 1996 (Table 4-12). Lahaina has about 30,000 acres of land zoned Agricultural. One sugarcane plantation in that district, Pioneer Mill Co., covered about 6,000 acres in 1996. Pineapple production presently occupies about 3,600 acres. Thus, Lahaina district has about 26,500 acres available for other agricultural uses. This district is considered to be a potential location for ethanol-crop production.

Lands zoned Agricultural in the Wailuku and Makawao districts total about 176,000 acres. Sugarcane and pineapple lands, combined, cover about 43,000 acres, a small fraction of the total agricultural land. Very little land is used for growing other crops or for other agricultural purposes (e.g., cattle and sheep production). Large tracts of land zoned Agricultural are available for energy-crop production. One barrier against using lands not previously in sugarcane or pineapple for energy-crop production would be high establishment cost.

Table 4-11. Acreage in sugarcane and pineapple on Maui island, 1991 to 1997.

\begin{tabular}{|lrrrrrrr|}
\hline$\underline{\text { CroplYear }}$ & $\underline{1991}$ & $\underline{1992}$ & $\underline{1993}$ & $\begin{array}{r}\underline{1994} \\
\text { (acres) }\end{array}$ & $\underline{1995}$ & $\underline{1996}$ & $\underline{1997}$ \\
$\begin{array}{l}\text { Sugarcane } \\
\text { Pineapple }\end{array}$ & 42,500 & 42,200 & 42,100 & 41,900 & 42,600 & 42,272 & 42,460 \\
& 15,700 & 14,100 & 10,900 & 10,800 & 9,500 & $\sim 9,600$ & $\sim 8,200$ \\
1. Hawaiian Sugar Planters' Association (1997); Serno (1998); Moore (1998). & \\
2. Nohara (1998); Fleisch (1998).
\end{tabular}


Table 4-12. Major plantations on Maui island, 1996.

\begin{tabular}{|lllr|}
\hline Crop & Company & Location & Cropland (acres) \\
Sugarcane ${ }^{1}$ & Pioneer Mill Co., Ltd & Lahaina & 5,896 \\
& Hawaiian Commercial \& Sugar Co. & Wailuku, Makawao & 36,376 \\
Pineapple & Maui Pineapple Company Ltd. & Wailuku, Makawao & $\sim 6,100$ \\
& Maui Pineapple Company, Ltd & Lahaina & $\sim 3,600$ \\
Total & & $\sim 52,000$ \\
1. Hawaiian Sugar Planters' Association (1997). & \\
2. Nohara (1998); Fleisch (1998). & & \\
\hline
\end{tabular}

\subsubsection{Kauai}

Major agricultural uses of lands on the island of Kauai are summarized in Table 4-13, and crop acreage from 1991 to 1997, in Table 4-14. Sugarcane and coffee are the major crops on Kauai, with sugarcane acreage being about six times as large as that in coffee. Other crops occupy only about 2,000 acres, less than $10 \%$ the acreage in sugarcane. Locations of sugarcane plantations are shown in Fig. 4-2.

Table 4-13. Major agricultural use of land on Kauai, 1995.1
$\underline{\text { District }}$
Agricultural Uses, 1995
Kauai Island
Sugar, cattle, hogs, bananas, guavas, papayas, taro, seed crops, coffee, flowers and nursery products, vegetables.

1. Hawaii Agricultural Statistics Service (1996).

Table 4-14. Acreage in crops on Kauai, 1991 to 1997.1

\begin{tabular}{|lrrrrrrrr}
\hline CroplYear & $\underline{1991}$ & $\underline{1992}$ & $\underline{1993}$ & $\underline{1994}$ & $\underline{1995}$ & $\underline{1996}$ & $\underline{1997}$ \\
& & & & & & & \\
Sucres) & 34,000 & 33,700 & 33,600 & 34,500 & 30,800 & 26,500 & $25,426^{3}$ \\
Coffee & 4,800 & 4,300 & 2 & 2 & 2 & 2 & 4 \\
Pineapple & $<50$ & $<50$ & $<50$ & $<50$ & $<50$ & $<50$ & 4 \\
Vegetables and melons (harvested & 100 & $<50$ & 100 & $<50$ & 100 & 100 & 4 \\
All other crops & 800 & 700 & 1,100 & 1,200 & 1,500 & 1,600 & 4 \\
1. Hawaii Agricultural Statistics Service (1997). & & & & & \\
2. Statistical data not available for this crop. & & & & & & \\
3. Sylvester (1998); Wachi (1998). & & & & & & & \\
4. 1997 data not available. & & & & & & & &
\end{tabular}

Total sugarcane acreage on Kauai was about 25,400 acres in 1997, less than 50\% the 52,300 acres in 1969. The major sugarcane companies on Kauai in 1988 and in 1997 are listed in Table 4-15. McBryde Sugar Company, with about 11,300 acres of sugarcane land, ceased operating in 1996. Amfac Sugar 
Company reduced its sugarcane acreage by about 5,000 acres. Most of the former sugarcane lands, totaling about 16,000 acres, are available for other agricultural activities. One such activity is forestry. Eucalyptus is scheduled to be planted on former sugarcane lands on Kauai to generate wood products (Dudley, 1998). Plans call for two Eucalyptus plantations, each occupying 5,000 acres. Thus, only about 5,000 acres of abandoned sugarcane lands are available for other agricultural purposes.

Table 4-15. Major sugarcane plantations on Kauai.

\begin{tabular}{|l|l|r|r|}
\hline Company & Location & \multicolumn{2}{c|}{ Cropland (acres) } \\
\hline & & $1988^{1}$ & $1997^{2}$ \\
\hline Amfac Sugar Kauai-Western Operations & Kekaha & 8,375 & 7,366 \\
\hline Amfac Sugar Kauai-Eastern Operations & Lihue & 14,744 & 10,717 \\
\hline Gay \& Robinson, Inc. & Kaumakani & 2,742 & 7,343 \\
\hline Olokele Sugar Co. & Olokele & 4,747 & 3 \\
\hline McBryde Sugar Co. & Koloa & 11,296 & 4 \\
\hline Total & & 41,904 & 25,426 \\
\hline 1. Hawaiian Sugar Planters' Association (1989). & & \\
\hline 2. Sylvester (1998); Wachi (1998). & & & \\
\hline 3. Purchased by Gay \& Robinson, Inc., in 1994. & & \\
\hline 4. Production ceased on September 13, 1996. & & \\
\hline
\end{tabular}

It is noted that of the 140,000 acres zoned Agricultural on Kauai, only about one-third (50,000 acres) is being farmed. Although some lands are being used for other agricultural purposes (e.g., for cattle and sheep), large amounts of land zoned Agricultural are unused. The 5,000 acres of unused former sugarcane land plus the undeveloped agricultural lands on Kauai are available for ethanol-crop production. Most of the abandoned sugarcane land is located along the southern and eastern coasts of the island. This area is selected as a potential location for ethanol-crop production.

\subsection{Candidate Sites - Results of Land Availability Analysis}

Potential energy-crop lands on the four major islands in the State of Hawaii were assessed by Phillips et al. (1992) assuming that only those lands classified as "Probably Available" (with concerns in specific areas) or Available (no concerns identified) would be available for energy-crop production. The results of their assessment, presented in Table 4-16, suggest that large amounts of land are available for energy-crop production on the four islands being considered here. Most of the lands, however, have not been developed for crop production.

The preceding analysis of land availability on the islands of Oahu, Hawaii, Maui, and Kauai, indicates that large tracts of lands zoned Agricultural are available for crop production. But most of them have not been farmed in the past and the cost to develop these lands for energy-crop production would be high. Decline of sugarcane production in Hawaii provides the opportunity to use former sugarcane lands for ethanol-crop production. The candidate sites, summarized in Table 4-17, are located in sites zoned Agricultural and, as discussed above, were selected on the basis of historic use. Most of the sites selected have been or are being used for crop production, thus minimizing the cost for land conversion. 
Table 4-16. Land availability analysis for biomass (Phillips, et al., 1992; no data for Oahu).

\begin{tabular}{|l|r|r|r|r|r|}
\hline Island & Available & Probable & $\underline{\text { Possible }}$ & Unlikely & Unavailable \\
\hline & & & (acres) & & \\
\hline Hawaii & 799,369 & 182,854 & 90,439 & 105,759 & 19,274 \\
\hline Maui & 214,977 & 24,216 & 23,722 & 5,189 & 988 \\
\hline Kauai & 107,736 & 27,428 & 20,015 & 3,212 & 988 \\
\hline
\end{tabular}

Table 4-17. Candidate sites for ethanol-crop plantation on four islands.

\begin{tabular}{|c|c|c|c|c|c|c|c|}
\hline \multirow[t]{2}{*}{$\underline{\text { Island }}$} & $\underline{\text { Candidate Site }}$ & \multicolumn{2}{|c|}{ Land Size Land Usage } & \multicolumn{3}{|c|}{ Biomass Yield Potential (ton/day?) } & \multirow[b]{2}{*}{ Trees } \\
\hline & & (acres) & & Sugarcane & Grass (irr) & Grass (unirr) & \\
\hline \multirow[t]{2}{*}{ Oahu } & Waialua & $\sim 12,000^{3}$ & $<1>$ & 720 & 880 & 720 & 400 \\
\hline & Ewa & $\sim 13,500^{4}$ & $<1>$ & 810 & 990 & 810 & 450 \\
\hline \multirow[t]{2}{*}{ Hawaii } & Ka'u & $\sim 7,000^{5}$ & $<1>$ & 420 & 513 & 420 & 233 \\
\hline & Hamakua/N. Hilo & $\sim 20,000^{5}$ & $\langle 1\rangle,\langle 2\rangle$ & 1,200 & 1,467 & 1,200 & 667 \\
\hline \multirow[t]{2}{*}{ Maui } & Lahaina & $6,000^{6}$ & $<1>$ & 360 & 440 & 360 & 200 \\
\hline & Wailuku/Makawar & $\sim 20,000$ & $\langle 1\rangle$ or $\langle 2\rangle$ & 1,200 & 1,467 & 1,200 & 667 \\
\hline Kauai & Koloa/Lihue & $\sim 7,000^{7}$ & $<1>$ & 420 & 513 & 420 & 233 \\
\hline \multicolumn{8}{|c|}{ 1. $\langle 1\rangle$ : former crop land (mostly sugarcane); } \\
\hline \multirow{3}{*}{\multicolumn{8}{|c|}{$\begin{array}{l}\text { 2. Acreage yields of crops refer to Table 3-7; } 300 \text { days/year; irr=irrigrated; unirr=unirrigrated. } \\
\text { 3. Land acreage at Waialua Sugar Co., Inc. (approximate). }\end{array}$}} \\
\hline & & & & & & & \\
\hline & & & & & & & \\
\hline \multicolumn{8}{|c|}{ 4. Land acreage at Oahu Sugar Co., Ltd. (approximate). } \\
\hline \multicolumn{8}{|c|}{ 5. 1991 sugarcane acreage minus less planned Eucalyptus acreage. } \\
\hline \multicolumn{8}{|c|}{ 6. About 6,000 acres of former sugarcane land. } \\
\hline \multicolumn{8}{|c|}{ 7. Acreage at McBryde Sugar Co., Ltd. in 1991 less planned Eucalyptus acreage. } \\
\hline
\end{tabular}




\section{Suitability of Candidate Sites}

Land suitability refers to the ability of a given site to support the production of a crop in a sustainable manner. Although economics is the main factor that determines whether a certain tract of land would be used for ethanol-crop production, economic feasibility is not considered in assessing land suitability. Land ownership, per se, is not a deciding factor in assessing suitability, but ownership can place restrictions on the timing in which a targeted parcel of land becomes available and on the specific use of that land; therefore, ownership of the candidate sites is examined. The suitability of short-rotation intensiveculture energy-crop production depends largely on the types and amounts of agronomic inputs needed to attain a targeted yield, which are highly site specific. Agronomic factors considered in this investigation that influence the suitability of a certain parcel of land to produce energy crops include climate (temperature, rainfall, and insolation), topography (elevation, slope), soil characteristics, and water availability.

\section{$5.1 \quad$ Ownership}

Land owners in the State of Hawaii can be classified as federal government, State, Hawaiian Homes Commission (HHC), large private landowners, and small private landowners. Approximately 2,200,000 acres $(910,000$ hectares), or $55 \%$ of the land in the State, is privately owned. Large private landowners control about $42 \%$, and small private landowners about $13 \%$, of the total land in the State. Most of the remaining land, 1,300,000 acres (530,000 hectares) or 32\% of the total area, is controlled by the State of Hawaii. The HHC controls 190,000 acres (76,000 hectares) of land, about 5\% of the total area. HHC lands are designated Agricultural. The federal government controls more than 300,000 acres (120,000 hectares) of land, about $8 \%$ of the total area. Land ownership on the four islands, Oahu, Kauai, Maui, and Hawaii, in 1996 is shown in Fig. 5-1.

Lands owned by the federal government reside mostly in national parks or national wildlife refuges, or in the military, and therefore generally would not be very suitable for crop production. Similarly, much of the lands owned by the State that are not in agriculture likely would not be suitable for ethanol-crop production. Therefore, most of candidate sites for ethanol-crop production are owned privately, especially by large land owners.

Table 5-1 summaries land ownership for the seven candidate sites. From an administrative standpoint, the fewer owners that control a site, the better. It is noted that each site being considered is controlled by only two or three owners.

\subsection{Topography}

Slope and elevation of a parcel of land impact its suitability for crop production. Lands having slopes below $10 \%$ are more suitable for crop production than steeper terrain because irrigation, mechanical cultivation, and harvesting can be performed more efficiently. Ranges of land slope and elevation for the candidate sites are presented in Table 5-2. The majority of the candidate sites, Waialua, Wailuku/Makawao, and Koloa/Lihue, have slopes below 10\%. Although some parcels of land in other sites, Ewa, Ka'u, Hamakua/North Hilo, Lahaina, have slopes that exceed 10\%, most of the lands presently or formerly used for agriculture (primarily for sugarcane) in these sites have slopes below 10\%. Generally, lands closer to the ocean are relatively flat, while lands further inland are steeper.

Ethanol-crop production field equipment should not have much difficulty operating in existing agricultural lands because the equipment used for cultivation and harvesting would be similar to those presently used in agriculture. 


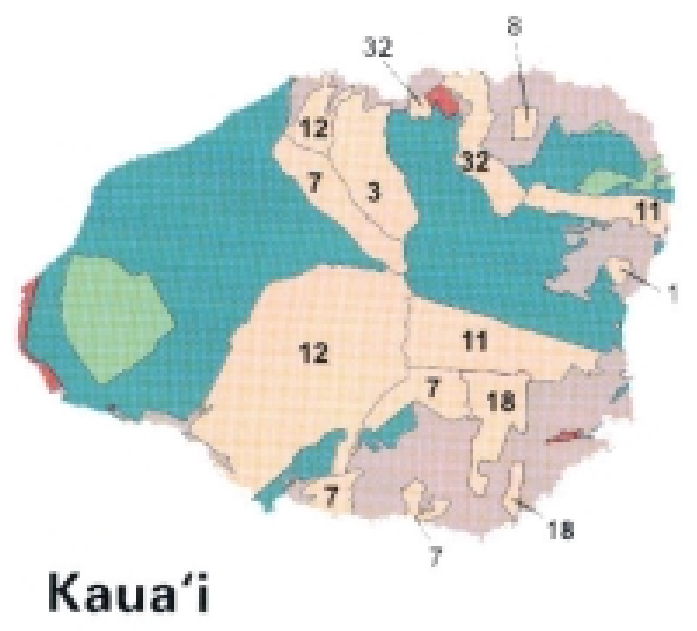

\section{Largest Landowners in Hawai'i, 1996}

\begin{tabular}{|c|c|}
\hline State of Hawai' (1) & $1,202,900$ acres \\
\hline Hawailian Home Lands (1) & 190,299 acres \\
\hline Federal Government (2) & 338,000 acres \\
\hline $\begin{array}{l}\text { Major Private Landowners } \\
\text { (greater than } 5,000 \text { acres) }\end{array}$ & $1,566,037$ acres \\
\hline $\begin{array}{l}\text { Small Private Landowners } \\
\text { (less than } 5,000 \text { acres) }\end{array}$ & 813,740 acres \\
\hline
\end{tabular}
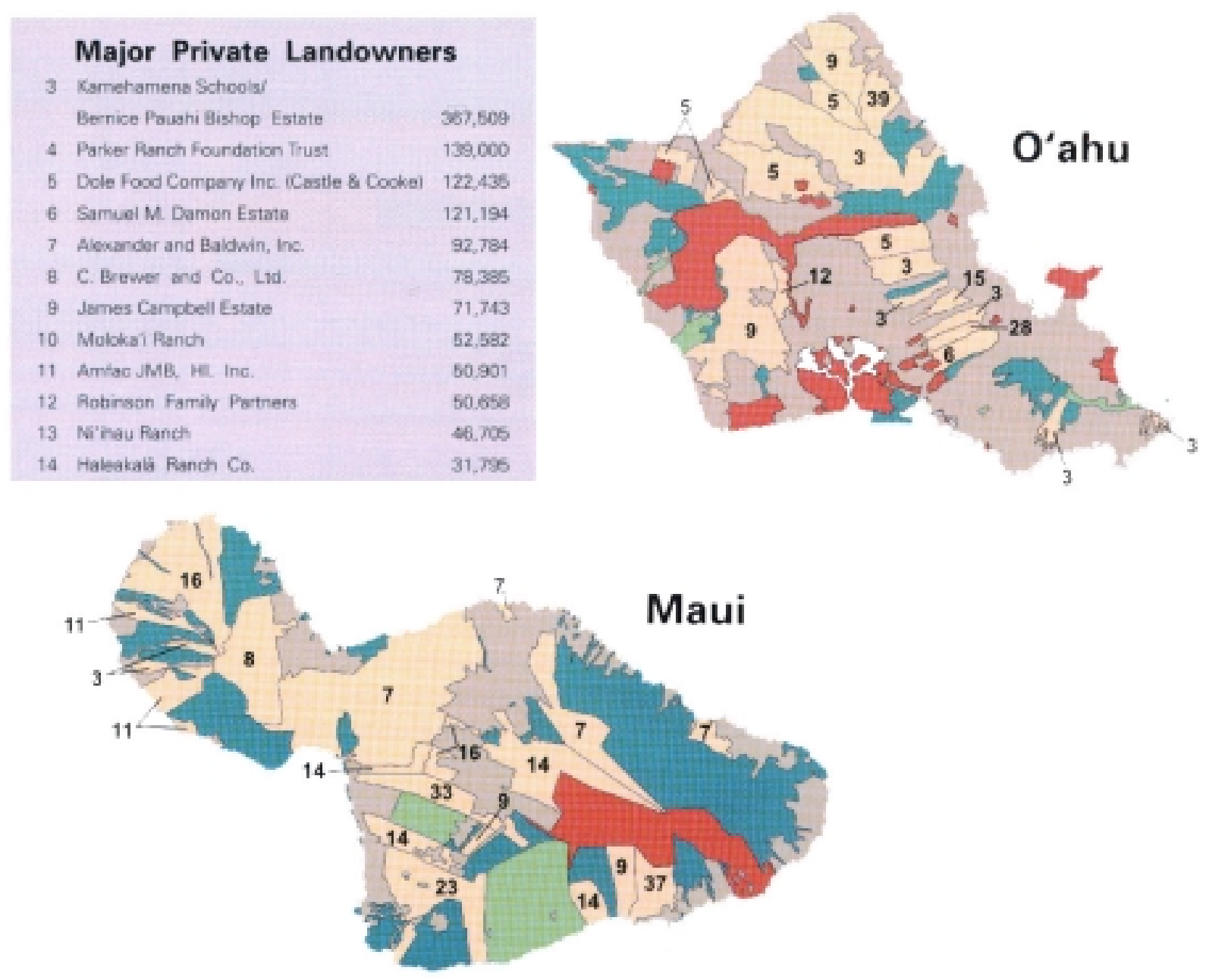

Fig. 5-1. Land ownership on four major islands. 


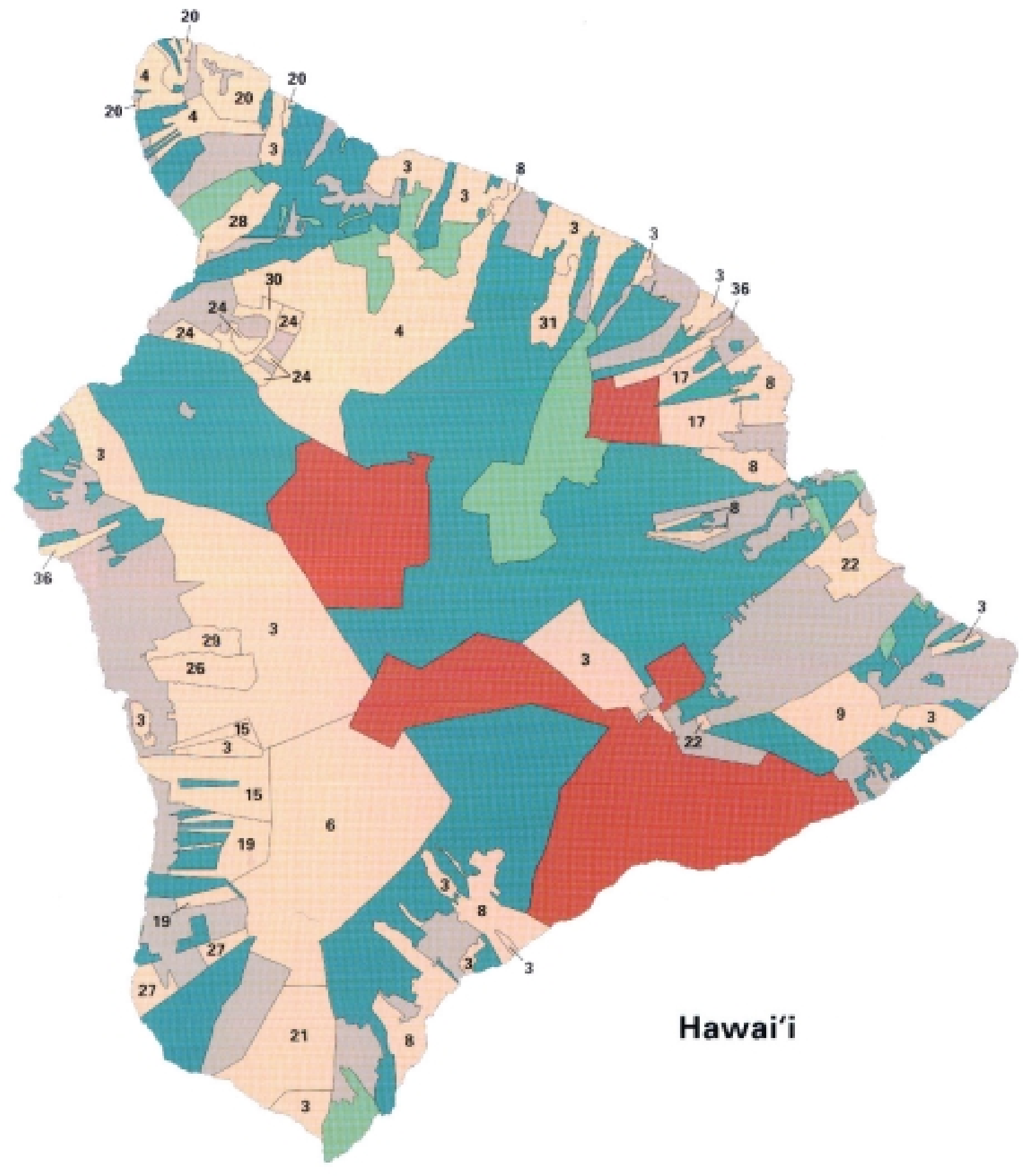

Fig. 5-1 (continued). Land ownership on four major islands. 
Table 5-1. Land ownership of candidate sites. ${ }^{1}$

\begin{tabular}{|c|c|c|}
\hline Island & Site & $\underline{\text { Major Owners }}^{2}$ \\
\hline \multirow[t]{2}{*}{ Oahu } & Waialua & 3,5 \\
\hline & Ewa & 9, others \\
\hline \multirow[t]{2}{*}{ Hawaii } & Ka'u & $1,3,8$, others \\
\hline & Hamakua/North Hilo & $1,3,4,8$, others \\
\hline \multirow[t]{2}{*}{ Maui } & Lahaina & $1,3,11$ \\
\hline & Wailuku/Makawao & 7,14 \\
\hline \multirow[t]{15}{*}{ Kauai } & Koloa/Lihue & 7,18, others \\
\hline & Number & Owner \\
\hline & 1 & State of Hawaii or Hawaiian Home Land \\
\hline & 2 & Federal Government \\
\hline & 3 & Bernice Pauahi Bishop Estate \\
\hline & 4 & Parker Ranch Foundation Trust \\
\hline & 5 & Dole Food Company Inc. (Castle \& Cooke) \\
\hline & 6 & S. M. Damon Estate \\
\hline & 7 & Alexander and Baldwin Inc. \\
\hline & 8 & C. Brewer and Co., Ltd. \\
\hline & 9 & James Campbell Estate \\
\hline & 11 & Amfac Inc. \\
\hline & 14 & Haleakala Ranch \\
\hline & 18 & Grove Farm Co., Inc. \\
\hline & Other & Other private landowners \\
\hline \multicolumn{3}{|c|}{ 1. University of Hawaii at Hilo (1998). } \\
\hline
\end{tabular}

The landscape of candidate sites can be classified into two broad categories: (1) low- and midelevation lands at altitudes below 1,000 feet, and (2) mountain areas above 1,000 feet elevation. The elevation data in Table 5-2 show that most of the lands in the candidate sites, except in the Ka'u and Hamakua/North Hilo sites, are at low- and mid-elevations. Some lands in the Ka'u and Hamakua/North Hilo sites also are below 1,000 feet, especially those lands currently in agriculture.

\subsection{Climatic Conditions}

The climatic conditions, including insolation, average temperature, and mean annual rainfall, for the seven candidate sites are summarized in Table 5-3.

The average temperature in the Ewa and Koloa/Lihue sites exceeds $70^{\circ} \mathrm{F}$; these are considered to be high temperature sites. Sites in Waialua, Hamakua/North Hilo, Lahaina, and Wailuku/Makawao, have temperatures in the range $65-75^{\circ} \mathrm{F}$; these are mid-temperature sites. The temperature for the Ka' $\mathrm{u}$ site is lower than the other sites, between $60^{\circ} \mathrm{F}$ and $72^{\circ} \mathrm{F}$. 
Table 5-2. Slope and elevation of candidate sites. ${ }^{1,2}$

\begin{tabular}{|c|c|c|c|}
\hline$\underline{\text { Island }}$ & $\underline{\text { Site }}$ & $\frac{\text { Slope }}{(\%)}$ & $\frac{\text { Elevation }}{(\mathrm{ft})}$ \\
\hline \multirow[t]{2}{*}{ Oahu } & Waialua & $0 \sim 10$ & $0 \sim 1,200$ \\
\hline & Ewa & $0 \sim 20$ & $0 \sim 1,000$ \\
\hline \multirow[t]{2}{*}{ Hawaii } & Ka'u & $0 \sim 35$ & $750 \sim 2,500$ \\
\hline & Hamakua/North Hilo & $0 \sim 20$ & $0 \sim 3,200$ \\
\hline \multirow[t]{2}{*}{ Maui } & Lahaina & $0 \sim 20$ & $0 \sim 1,600$ \\
\hline & Wailuku/Makawao & $0 \sim 10$ & $0 \sim 1,200$ \\
\hline Kauai & Koloa/Lihue & $0 \sim 10$ & $0 \sim 1,000$ \\
\hline \multicolumn{4}{|c|}{$\begin{array}{l}\text { 1. Hawaii Natural Energy Institute (1994). } \\
\text { 2. University of Hawaii (1965); (1967 (a)); (1967 (b)); (1972). }\end{array}$} \\
\hline
\end{tabular}

Table 5-3. Climatic conditions at candidate sites. ${ }^{1,2}$

\begin{tabular}{|c|c|c|c|c|}
\hline$\underline{\text { Island }}$ & $\underline{\text { Site }}$ & $\frac{\text { Insolation }}{\left(\mathrm{cal} / \mathrm{cm}^{2}-\text { day }\right)}$ & $\frac{\text { Average Temperature }}{\left({ }^{\circ} \mathrm{F}\right)}$ & $\frac{\text { Annual Rainfall }}{\text { (inches) }}$ \\
\hline \multirow[t]{2}{*}{ Oahu } & Waialua & $420 \sim 500$ & 69 74 & $20 \sim 80$ \\
\hline & Ewa & $420 \sim 525$ & $71 \sim 77$ & $20 \sim 50$ \\
\hline \multirow[t]{2}{*}{ Hawaii } & Ka'u & $325 \sim 400$ & $60 \sim 72$ & $60 \sim 100$ \\
\hline & Hamakua/North Hilo & $350 \sim 425$ & $64 \sim 74$ & $60 \sim 180$ \\
\hline \multirow[t]{2}{*}{ Maui } & Lahaina & $450 \sim 560$ & $68 \sim 75$ & $15 \sim 50$ \\
\hline & Wailuku/Makawao & $450 \sim 560$ & $68 \sim 75$ & $15 \sim 40$ \\
\hline Kauai & Koloa/Lihue & $350 \sim 450$ & $70 \sim 76$ & $20 \sim 110$ \\
\hline $\begin{array}{l}\text { 1. Haw } \\
\text { 2. Univ }\end{array}$ & $\begin{array}{l}\text { Natural Energy Institut } \\
\text { ty of Hawaii (1965); }\end{array}$ & $\begin{array}{l}\text { (1994). } \\
\text { 1967a);(1967b }\end{array}$ & b); (1972). & \\
\hline
\end{tabular}

Except in Ka'u, Hamakua/North Hilo, and parts of Koloa/Lihue, which have mean annual rainfall exceeding 100 inches, most of the prime agricultural lands at the other sites are arid or semi-arid, receiving far less than 100 inches of rainfall annually. The sites, Ka'u and Hamakua/North Hilo, and parts of Koloa/Lihue, are classified as wet sites, and the others as dry sites. The plant species grown for ethanol conversion needs to be compatible with the availability of water at a site. The highest yielding herbaceous crops considered in this investigation require 100 inches of water annually for optimal growth; therefore, if those crops are selected for the dry sites, irrigation would be needed.

Insolation at the sites in Waialua, Ewa, Lahaina, and Wailuku/Makawao, ranges from 420 to $500 \mathrm{cal}$ per $\mathrm{cm}^{2}$-day or higher. These locations generally coincide with lands that receive less rainfall. High insolation translates to high yield in crop production; however, irrigation will be needed due to the low rainfall in those sunny locations. Insolation at the other sites, Ka'u, Hamakua/North Hilo, and Koloa/Lihue, is lower (less than $450 \mathrm{cal}$ per $\mathrm{cm}^{2}$-day); these regions generally have higher rainfall. 


\subsection{Soil}

Ten different types of soils are found in the Hawaiian islands according to soil order: (1) Alfisols, (2) Aridisols, (3) Entisols, (4) Histosols, (5) Inceptisols, (6) Mollisols, (7) Oxisols, (8) Spodosols, (9) Ultisols, and (10) Vertisols (Fig. 5-2).

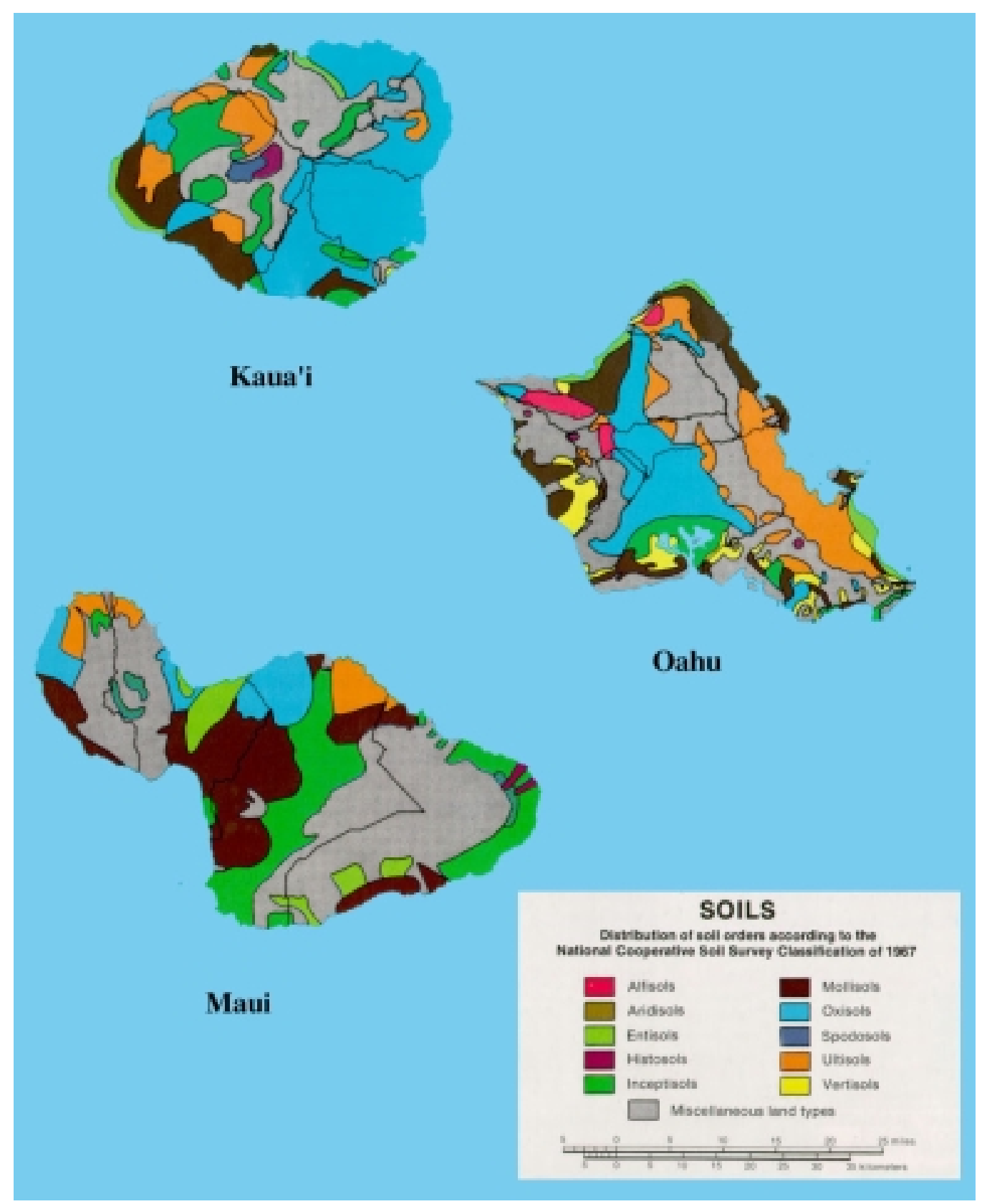

Fig. 5-2. Soil order distribution on four major islands.

Some locations fall into the category Miscellaneous Land Types, which typically are covered by rock, stone, and recently deposited material. Lands covered by Aridisols, Spodosols, and Miscellaneous Land Types generally are considered poor for agriculture. Most agricultural land in the State contain Histosols, Inceptisols, Mollisols, Oxisols, or Ultisols. The best soils for biomass production are Mollisols and Oxisols. Soil type at the candidate sites is summarized in Table 5-4. 


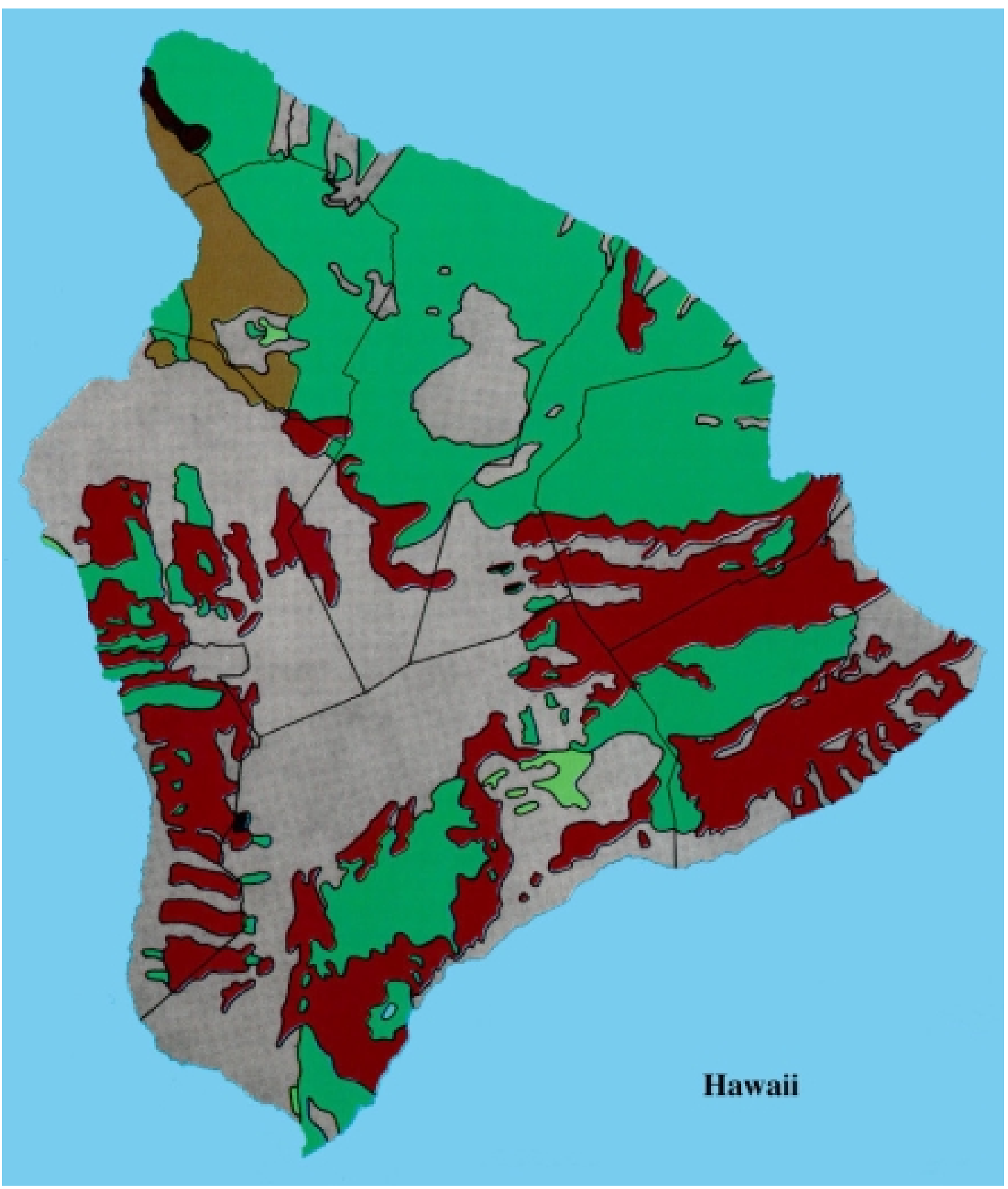

Fig. 5-2 (continued). Soil order distribution on four major islands.

Oxisols and Ultisols are found only on old geomorphic surfaces. Oxisols are found on relatively flat land in lower elevations, and Ultisols on steeper slopes and more unstable landscapes at higher elevations. Oxisols are the most weathered soil, with very high (up to 90\%) clay content. Properly managed, Oxisols are highly productive. Oxisols have high permeability and promote leaching of soluble plant nutrients, and have moderate water retention. Ultisols are highly weathered soils with low to moderate natural fertility, but are responsive to soil management. These soils show exceptional resistance to physical deterioration under intensively mechanized agriculture and are important agricultural soils in the islands. 
Table 5-4. Soils in candidate sites. ${ }^{1,2}$

\begin{tabular}{|c|c|c|}
\hline$\underline{\text { Island }}$ & $\underline{\text { Site }}$ & $\underline{\text { Soil Type }}$ \\
\hline \multirow[t]{2}{*}{ Oahu } & Waialua & $6,7,9$ \\
\hline & Ewa & $5,6,7,10$ \\
\hline \multirow[t]{2}{*}{ Hawaii } & Ka'u & 4,5 \\
\hline & Hamakua/North Hilo & $4,5,11$ \\
\hline \multirow[t]{2}{*}{ Maui } & Lahaina & 6,7 \\
\hline & Wailuku/Makawao & 3,6 \\
\hline \multirow[t]{13}{*}{ Kauai } & Koloa/Lihue & $5,6,7$ \\
\hline & $\underline{\text { Soil Type Number }}$ & \\
\hline & 1 & Alfisols \\
\hline & 2 & Aridisols \\
\hline & 3 & Entisols \\
\hline & 4 & Histosols \\
\hline & 5 & Inceptisols \\
\hline & 6 & Mollisols \\
\hline & 7 & Oxisols \\
\hline & 8 & Spodosols \\
\hline & 9 & Ultisols \\
\hline & 10 & Vertisols \\
\hline & 11 & Miscellaneous Land \\
\hline \multicolumn{3}{|c|}{$\begin{array}{l}\text { 1. Hawaii Natural Energy Institute (1994). } \\
\text { 2. University of Hawaii (1983); (1998). }\end{array}$} \\
\hline
\end{tabular}

Mollisols are well-drained, relatively young soils that develop on coral, lava, or alluvium. They are dark-colored soils, relatively high in organic matter, and rich in plant nutrients, and are found in moderately dry areas in the islands. Mollisols are excellent agricultural soils with natural fertility (although this varies with weather conditions).

Inceptisols are best developed on the thin mantle of volcanic ash. As young soils deficient in phosphorus, Inceptisols require relatively high fertilization for high crop yield. Although Inceptisols are not ideal for ethanol-crop production, they are used in cultivation of sugarcane and vegetables, and for pasture. Inceptisols are common in most areas of the islands.

Histosols are organic soils that are found on geologically young but forested lava land. This soil type is characteristically a thin ( 2 to 8 inches, or 5 to $20 \mathrm{~cm}$ ) layer of organic material accumulated on lava rock. This soil exists only in Ka'u and in very small areas in Hamakua/North Hilo.

\subsection{Selection of Three Most Suitable Sites}

The suitability analysis identified seven sites suitable for energy-crop cultivation, most of the which are being or have been farmed. An objective of this investigation is to identify three best site/crop combinations capable of supplying 300-1,000 tons (dry basis) of biomass feedstock per day to ethanol 
conversion facilities. Three best sites were selected from the seven candidates by comparing the factors which affect the suitability of these sites to ethanol-crop production.

The local market for ground transportation fuels impacts the feasibility of producing and selling ethanol, and local population and fuel consumption determine the size of the local market for transportation fuel. Population and fuel consumption in the four counties in the State of Hawaii are presented in Table 5-5. Of the four counties, Kauai has the lowest population and lowest fuel consumption. Because of this, the site on Kauai was dropped from further consideration.

Table 5-5. Population and fuel consumption in four counties in the State. ${ }^{1}$

\begin{tabular}{|lrc|}
\hline State and County & $\frac{\text { Resident }}{\text { Population }}$ & $\frac{\text { Highway Fuel }}{\text { Consumption }}$ \\
& $(1990)$ & $(1,000$ gallons, 1997) \\
State of Hawaii & $1,108,229$ & 421,499 \\
Oahu & 836,231 & 276,658 \\
Hawaii & 120,317 & 66,379 \\
Maui & 91,361 & 53,771 \\
Kauai & 50,947 & 24,691 \\
1. State of Hawaii (1998). & & \\
\hline
\end{tabular}

Land quality of each candidate site was graded according to agronomic conditions (land slope, elevation, insolation, and rainfall). In this analysis, each agronomic condition was categorized into one of three classes (Table 5-6). For example, land slope of $0 \sim 10 \%$ is considered as favorable and in this case, the parcel of land would be assigned into Class 3. The sum of all classes for a site is the land quality indicator for the site. Results of this land quality ranking are presented in Table 5-7.

Three most favorable sites on three islands were selected using the land quality data in Table 5-7. On Oahu, the Waialua site has a higher suitability classification than the Ewa site because of more favorable slope and rainfall. On Hawaii island, the Hamakua/Hilo site is better than the Ka'u site on the basis of slope and elevation. On Maui, the Wailuku/Makawao site was found to be more suitable that the Lahaina site.

Based on this analysis, the three most favorable sites for ethanol-crop production were determined to be at Waialua on Oahu, Hamakua/North Hilo on Hawaii island, and Wailuku/Makawao on Maui. Detailed discussions of these three sites are presented in other sections of this report.

Table 5-6. Agronomic conditions and land suitability grading.

\begin{tabular}{|c|c|c|c|c|c|}
\hline$\underline{\text { Suitability Class }}$ & $\underline{\text { Suitability }}$ & $\frac{\text { Slope }}{(\%)}$ & $\frac{\text { Elevation }}{(\mathrm{ft})}$ & $\frac{\text { Insolation }}{\left(\mathrm{cal} / \mathrm{cm}^{2}-\text { day }\right)}$ & $\frac{\text { Rainfall }}{\text { (inches) }}$ \\
\hline Class 3 & Good & $0 \sim 10$ & $0 \sim 1,200$ & $420 \sim 525$ & $>80$ \\
\hline Class 2 & Fair & $0 \sim 20$ & $0 \sim 3,200$ & $350 \sim 450$ & $50 \sim 80$ \\
\hline Class 1 & Poor & $0 \sim 35$ & $750 \sim 2,500$ & $325 \sim 400$ & $<50$ \\
\hline
\end{tabular}


Table 5-7. Summary of suitability analysis of six candidate sites.

\begin{tabular}{|c|c|c|c|c|c|c|}
\hline \multirow[t]{2}{*}{ Island } & \multirow[t]{2}{*}{$\underline{\text { Site }}$} & \multicolumn{4}{|c|}{$\underline{\text { Suitability Class }}$} & \multirow[t]{2}{*}{$\underline{\text { Total }}$} \\
\hline & & $\underline{\text { Slope }}$ & Elevation & Insolation & $\underline{\text { Rainfall }}$ & \\
\hline \multirow[t]{2}{*}{ Oahu } & Waialua & 3 & 3 & 3 & 2 & 11 \\
\hline & Ewa & 2 & 3 & 3 & 1 & 9 \\
\hline \multirow[t]{2}{*}{ Hawaii } & Ka'u & 1 & 1 & 1 & 3 & 6 \\
\hline & Hamakua/North Hilo & 2 & 2 & 1 & 3 & 8 \\
\hline \multirow[t]{2}{*}{ Maui } & Lahaina & 2 & 2 & 3 & 1 & 8 \\
\hline & Wailuku/Makawao & 3 & 3 & 3 & 1 & 10 \\
\hline
\end{tabular}




\section{Ethanol-Crop Production and Cost Predictions}

Energy-crop production costs are highly site specific, depending on such factors as scale of operation, agronomic inputs, irrigation water requirements, and type of harvesting and transporting system employed. Cost projections for producing and delivering biomass feedstocks to central conversion plants in Hawaii vary widely, from $\sim \$ 30$ to $\$ 100$ per ton (dry basis) (see Hubbard and Kinoshita 1993; Osgood and Dudley 1993; Phillips et al. 1993; Troy 1982; Whitesell et al. 1992).

In this investigation, cost projections for ethanol-crop production include various unit operations in cultivation. These unit operations are based on plantation experiences in grass and tree crops in Hawaii. The operational sequences are described briefly in this section. The analyses of this investigation terminate at the conversion plant gate - storage, additional processing, and biomass conversion are not included here.

\subsection{Unit Operations in Grass Crop Production}

Unit operations for the two grass species selected for investigation in Section 4, sugarcane and banagrass, are described below. Because sugarcane has been grown commercially in Hawaii for more than 150 years and has amassed considerable experience whereas banagrass production has largely been confined to demonstration scales, most of the discussion below focuses on the production sequences for banagrass (which are anticipated to be very similar to those for sugarcane).

\subsubsection{Soil Preparation}

In Hawaii, sugarcane fields normally need to be plowed and replanted after every harvest (i.e., the fields normally are not ratooned), owing to severe damage to the field caused by push-rake harvesting and in-field hauling by truck-trailer units that contain up to 50 tons of cane and extraneous material. Because of excessive compaction by heavy field equipment, in-field cane-haul roads require special treatment — large subsoilers, mounted behind track-type tractors, rip in-field roads to a depth of 22 inches. Assuming that less aggressive harvesting and transporting equipment would be employed for banagrass, soil preparation would differ from that used for sugarcane in types and sequencing of operations as well as in frequency of tillage. Mechanical harvesters, which cause less damage to fields than push rakes, and lighter haulers than are presently being used for sugarcane would be employed for banagrass; therefore, as in locations where such equipment are used for sugarcane, ripping of in-field roads would not be needed, nor would the fields have to be prepared after each harvest (it is assumed that five ratoon crops would be obtained after each planting, and that ratoon crops would need very little or no soil preparation).

Soil preparation for plant crops of banagrass would be similar to that of sugarcane plant crops: leveling, as necessary; cross-ripping (using a D-8 or equivalent tractor with 30-inch long shanks) and dragging; multiple passes with large disc harrows (42-inch); followed by rip-dragging the entire field. This practice should leave the soil prepared to a depth of 18 to 22 inches. Ratoon fields would need little or no preparation.

The soil preparation practices for banagrass in fields to be seeded ("plant" fields) are assumed to be similar to those used for sugarcane. The direct labor requirement (ripper and disc-harrow operators) would be three operator-hours or more per acre prepared. Additional labor would be needed for leveling and related operations, bringing the total labor input to about four hours per acre prepared. Additional cost factors for soil preparation include fuel and other equipment charges (e.g., maintenance, which represents roughly one-fourth of the total cost of this operation), and indirect costs (e.g., insurance and depreciation). 
It is assumed that the soil is tilled only prior to planting, and that the soil would not be tilled in ratoon crops; therefore, soil-preparation costs largely would be incurred only in plant crops while ratoon crops would not incur soil preparation costs (although, if deemed necessary, some subsoiling and reshaping of banagrass lines might be advisable for the later ratoons as tillering progresses). The labor and machine requirements for such operations in ratoon crops are very modest compared with plant crops; e.g., labor requirements for ratoon sugarcane fields, excluding preparation of in-field cane-haul roads, typically are one order of magnitude lower than those for plant sugarcane fields.

\subsubsection{Seed Production}

As mentioned in the preceding section, it is assumed that each plant (seeded) crop of banagrass would be followed with five ratoon crops before the field is plowed and seeded again (note that banagrass cultivation experience on Molokai suggests that it might be possible to obtain ten or more ratoon crops from each plant crop without suffering significant decline in yield). The banagrass would be harvested using mechanical harvesters intended for cutting erect cane which usually produces satisfactory ratoon stands needing little or no replanting of voids. Because only one in six crops would be planted, the amount of seed needed per acre cultivated would be vastly reduced.

Banagrass would be vegetatively propagated using cuttings of the plant stalk (seed pieces). Although selected areas could be set aside specifically for seedcane production, having different rowspacings and inputs, this probably would not be necessary given the rather modest seed requirement. The seed pieces would be $~ 12-15$ inches long, cut from seven- or eight-month old banagrass using the same equipment employed in harvesting the commercial crop. However, care should be exercised to inflict minimal damage to the seed pieces during cutting so that survival and germination rates remain high, and there is little need for replanting.

As experienced in the ten-acre demonstration on Molokai, owing to its less-recumbent, more-erect nature, banagrass is easier to cut mechanically than sugarcane of the same age. The similarity in equipment used for harvesting banagrass seed versus banagrass crop enables integration of both operations (by contrast, in Hawaii, the equipment used for harvesting sugarcane seed is dramatically different from that used in harvesting the commercial sugarcane crop) thereby yielding substantial savings in equipment operation and maintenance, and in transporting seed to the plant field. Treating of sugarcane seed pieces with fungicide is known to be beneficial but little information is available on the effect of such treatments.

In this investigation, it is assumed that the cost of producing and delivering banagrass seed to the planted field would be equivalent to that for sugarcane (on a per ton basis). Because the rate of application (tons of seed applied per acre) of banagrass seed would be dramatically lower than for sugarcane, the cost of producing and delivering seed to the planted field would likewise be reduced on a per-acre planted basis.

\subsubsection{Planting}

Because banagrass stalks have only about one half the diameter of sugarcane stalks, the amount (weight) of banagrass seed applied per acre would be only about one-fourth that for sugarcane (assuming the same degree of overlap of seed pieces placed in the seed furrow). The banagrass seed pieces would be planted in furrows at a depth of $<4$ inches, and a density of 1.0 to 1.5 tons per acre, using mechanical planters similar to those used for sugarcane in Australia or in Hawaii (Fig. 6-1 shows rows of newly planted sugarcane which resemble planted banagrass). This seeding density, while significantly lower than the rate applied for sugarcane (typically $\sim 3$ tons per acre), still represents a substantial supply above the $\sim 0.7$ tons per acre of seed planted in the ten-acre banagrass demonstration on Molokai. The high application rate proposed is meant to compensate for the generally weak plant-crop stand with banagrass. Typical productivities of mechanical planters being used for sugarcane in Hawaii are $\sim 1$ acre per hour. Planters 
typically are manned by one operator and several workers on the machine who help to meter seed and on the ground to redistribute seed species, plus a loader operator to deliver seed to the planter. Combined, the labor requirement (not including that for producing seed) is less than 10 worker-hours per acre planted. In irrigated locations, drip irrigation tubing and fertilizer $(\mathrm{N}, \mathrm{P}, \mathrm{K})$ would be injected the time of planting.

Even though the amount of seed applied per acre would be lower with banagrass than with sugarcane, (e.g., 1.0-1.5 tons per acre for banagrass versus 3-4 tons per acre for sugarcane), in this investigation, the cost of planting banagrass (per acre planted basis) is assumed to be the same as for sugarcane. This probably overstates the cost of planting banagrass - although the ground speed of the banagrass planter likely would be comparable to that for sugarcane, because the seed application rate would be substantially lower, the percentage of time lost to restocking planting machines should drop markedly, thereby increasing the overall productivity (acres per hour) of the planting operation.

Averaged over several crops, the frequency of planting would be much lower for banagrass than for sugarcane owing to the large number of ratoons anticipated from each plant crop. The cost of producing and planting banagrass seed would be commensurately lower.

\subsubsection{Fertilization}

Although dependent on soil conditions, typically, sugarcane needs about $150 \mathrm{lb} \mathrm{N}$ per acre-year, 150 $\mathrm{lb} \mathrm{K}$ per acre-year, and $100 \mathrm{lb} \mathrm{P}$ per acre-year. Fertilizer requirements for banagrass are higher than those for sugarcane (nutrients are assumed to be $35 \%$ greater for banagrass than sugarcane). In order to produce near-maximum yields, $>200$ pounds per acre of $\mathrm{N},>200$ pounds per acre of $\mathrm{K}$, and significant levels (50-250 pounds) of $\mathrm{P}$ would be needed annually to support banagrass production. These would be applied initially with the planter as solid fertilizers, and monthly, thereafter, though the drip irrigation tubing in soluble formulations containing $\mathrm{N}$ and $\mathrm{K}$.

Because the fertilizers would be applied mostly via the irrigation system, labor requirements would be minimal and the overall cost for fertilization would consist largely of the cost of the fertilizer material itself (e.g., for sugarcane production at WSCo, materials represent $80 \%$ of the total cost of fertilization). In this study, fertilization cost for banagrass was assumed to be $30 \%$ higher than for sugarcane.

\subsubsection{Weed Control}

Good weed control is important for ensuring optimal biomass productivity. The most critical stage for weed control is during the first two months after planting, when the crop faces the greatest competition from weeds. Good tillage aids weed control by creating a friable, aerated medium for energy-crop roots, eliminating existing weeds, and burying weed seeds. Considerably less weed control would be required for ratoon crops owing to rapid canopy closure following harvest and to vegetative ground cover left by harvesting operations. It is essential to have uniform stands of plant or ratooned banagrass to ensure highstalk population for rapid canopy closure and high yield; high seeding density and rapid tillering minimize weed problems. A healthy crop can compete effectively with most annual weeds and is less susceptible to herbicide damage; therefore, water and fertilizers should be applied in a disciplined manner. Drip irrigation reduces the density of weeds by irrigating only the crop rows and keeping the interrows dry and largely free of weeds.

The installation by HSPA of several banagrass trials in Hawaii has led to the development of a weed control program which is expected to be effective for ethanol-crop production. Weed control for banagrass cultivation would need to differ from that used for sugarcane owing to the sensitivity of banagrass to a common sugarcane herbicide, ametryn, as experience has shown that banagrass is stunted severely by ametryn if the spray contacts the foliage. 
(a) View along cane lines.
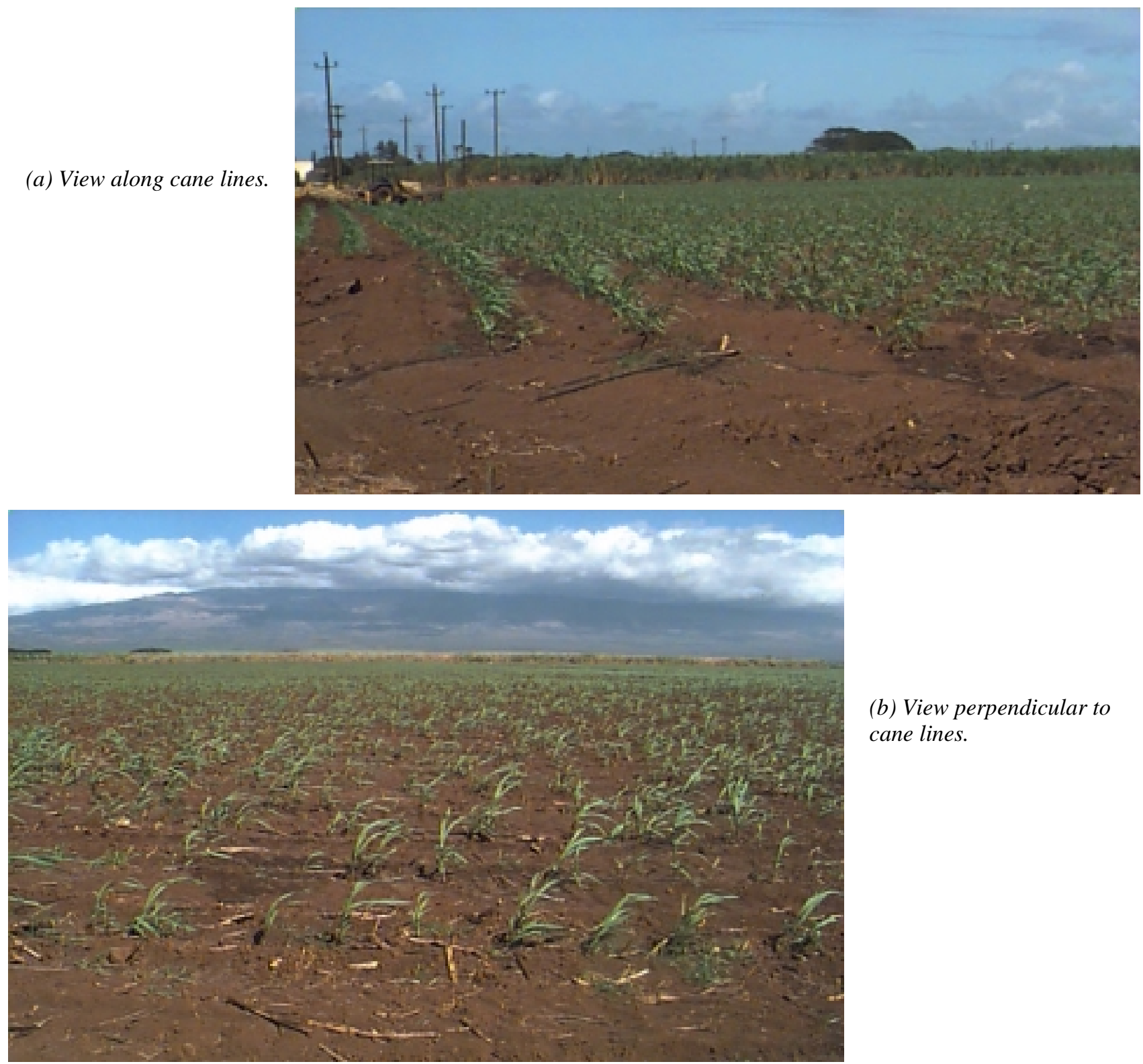

(b) View perpendicular to cane lines.

Fig. 6-1. Newly planted sugarcane at HC\&S, Maui.

The principal weeds in sugarcane culture include guineagrass (Panicum maximum), swollen fingergrass (Chloris inflata), and Aiea morningglory (Ipomoea triloba). Many other species are present but usually can be kept under control with an effective weed control program. Guineagrass should be controlled prior to planting by spraying the grass stools with Roundup ( $2 \%$ by volume in water). Ammonium sulfate should be added to increase Roundup activity. It is anticipated that banagrass would be infested with the same weeds as sugarcane because banagrass would be grown largely in areas previously in sugarcane and because of the similar growth patterns of both crops during the first six months.

Weed control in the plant crop would consist of applications of pre-emergence and post-emergence herbicides. In pre-emergence weed control, a combination of atrazine (at 2.5 pounds per acre) and either alachlor, trifluralin, or pendamethalin (at 2.5 pounds per acre) should be applied. Application should be made by a tractor-mounted boom at about 50 gallons per acre within ten days of planting. Post-emergence weed control would consist of carefully spot-treating guineagrass and other grass weeds with Roundup. Broadleaf weeds should be treated with 2.4-D or atrazine. 
Weed growth is expected to be much lighter in the ratoon crop than in the plant crop, owing to the rapid regrowth of banagrass and the anticipated vegetative blanket on the ground remaining from the previous harvest. Pre-emergence application, if needed, should follow the practice outlined above for plant crops. Spot treatments should be applied, as needed, using Roundup and 2.4-D.

Canopy closure should occur within eight weeks after planting (slightly longer during the winter), after which in-field weed control would not be needed. Vines such as Aiea morningglory could pose a problem if not controlled prior to canopy closure and along the edge of the field.

A mechanical spot-application system, called the Spider, can largely eliminate the need for hand application of herbicides and reduce weed control costs (about $20 \%$ labor reduction). The system was introduced in the Hawaiian sugar industry fairly recently and should play an important role in any effective weed control program for banagrass.

In this analysis, it is assumed that in the initial planting, the cost of weed control for banagrass is comparable to sugarcane on a per-acre-planted basis. Because banagrass ratoon crops close-in very rapidly, they should need very little weed control (this was the case in the ten-acre banagrass demonstration on Molokai and in several multi-acre demonstrations at WSCo in 1997). The cost of controlling weeds in banagrass ratoon fields is assumed to be only one-half the cost of spot application of herbicides in the plant crop; this cost represented only $\sim 20 \%$ of the total direct cost for weed control according to the records of one Hawaii sugar company.

\subsubsection{Irrigation}

Commercially grown banagrass would be drip irrigated in a manner similar to that practiced with Hawaiian sugarcane. This involves a network of plastic tubing with emitters that "trickle" or "drip" water to the plant in a manner that maintains soil moisture in the plant root zone as close to field capacity as possible during peak-use periods. This method of application is much more efficient in labor, water, and energy use than sprinkler or furrow irrigation.

The drip irrigation system consists of a supply line, which conveys water from a water source to a water treatment station (generally a bank of filter units and a chlorination system) and then to the mainlines that are usually buried to a depth of about 5 feet and maintained at 20-65 psi. A mainline typically serves hundreds of acres and is connected to a series of submain lines, which, in turn, serve as manifolds for the lateral drip irrigation tubes in 1 to 2 acre blocks. The only portion of the system that is replaced on a regular basis is the drip irrigation tubing; however, if the water used in the drip irrigation tubing is of sufficient quality and the tubing is buried slightly, $\sim 8-12$ inches deep, it is quite likely that the tubing could be left in the ground to be reused in ratoon crops and would have to be replaced only when a new crop is planted (every four years in this analysis). The tubing and banagrass rows could be spaced under different arrangements. For example, the banagrass rows could be spaced five feet apart (as in the ten-acre Molokai banagrass demonstration), with drip tubes placed 10-12 inches from each cane row; in this case, 8,700 feet of tubing would be required per acre. Alternatively, the banagrass could be spaced in a staggered fashion, e.g., alternating spacings of three feet, then six feet, then three feet, then six feet, ..., with one tube in the middle of the three-foot-spaced pair of cane rows (as being practiced at some sugarcane companies in Hawaii); this arrangement would require only 4,800 feet of tubing per acre and would provide significant cost savings for drip tubing.

The irrigation water required for crop production will depend on rainfall, evaporation, and other conditions at the site. For example, during the peak-use period at the Waialua site on Oahu, water would be applied at the designed delivery rate of 15 gallons per minute per acre, 12 hours per day. This design 
criterion is based on the assumptions that evapotranspiration from banagrass approaching maturity is approximately equal to pan evaporation and that water application efficiency under drip irrigation is $\sim 80 \%$. The system would be automated to control the water deliveries in the appropriate amounts and timing throughout the plant growth cycle, thereby optimizing the use of water for plant growth. Drip irrigation can facilitate precise control over the application of nitrogen and potassium fertilizers through their direct injection into the system.

Drip irrigation requires less labor than furrow systems and is easier to operate with proper training. Irrigators perform all necessary work related to water application except major repairs. They turn the system on and off, regulate supply water flows, backwash filters (if operations are not automated), check tube flushing, patrol the fields to ensure proper functioning of the system, and repair minor breaks and malfunctions. Pump failures and supply line breaks require major repairs, which are left to maintenance personnel. Typically, one irrigator can operate and maintain about 350 acres of irrigated crop land, and in some instances as much as 1,000 acres. The average level is projected to be 500 acres per operator. Additional personnel needed to support the drip irrigation system include the maintenance crew, consisting of one worker per 2,000 acres, to repair major equipment (mainlines, submains, risers, filtration systems, etc.), and a tubing installation crew, with a productivity exceeding eight acres per worker-day, to connect tubing to the submains whenever the tubing is replaced. The size of the support crew could be increased or decreased depending on the amount of damage to the irrigation system.

Because the tubing (costing about $\sim \$ 125$ per acre for materials and labor, per installation) would be replaced only once every four years or so, installation and material costs for banagrass production would be about one-half that for sugarcane. To ensure that the service life for irrigation tubing can be extended to four or five years, questions such as optimal depth of placement still need to be answered.

\subsubsection{Harvesting and Transporting}

Harvesting and transporting generally represent the largest components in the delivered cost of most energy crops (e.g., refer to Cundiff and Harris, 1995, for switchgrass; Hubbard and Kinoshita, 1993, for banagrass and Leucaena; Whitesell et al., 1992, for Eucalyptus). In this investigation, harvesting and transporting are discussed together because the distinction between both operations is not always obvious. For example, it is not clear whether in-field hauling of the chopped banagrass to the edge of the field for transfer into highway transporting units logically should be included as part of the harvesting or the transporting operation.

Banagrass would be harvested, nominally, at about eight months of age. Because terminal growth of banagrass ceases once flowering occurs (which takes place during the months of January to April in banagrass crops exceeding four months of age), the harvesting schedule would have to be adjusted to avoid flowering. Flowering depends on temperature and the length of daylight; therefore, the extent of flowering would vary from year to year and throughout the plantation.

The primary banagrass harvesting and transporting systems considered in this investigation are based largely on commercial sugarcane equipment similar to those used in some industrialized cane sugar industries, most notably for crop cane in Australia and the mainland U.S., and for seed cane in Hawaii. The harvester would gather and cut standing banagrass into billets approximately 12-15 inches long. Because such harvesters (e.g., the Austoft Model 7000 and the Claas Model CC 1400 sugarcane chopper harvesters) are often used for harvesting unburned cane, they should be directly applicable to banagrass without significant modifications to equipment or practices. (The only modification would be the disabling of the leaf extractors as maximum recovery of biomass is desired.) The harvested material, having a bulk density of about 8 pounds per cubic foot, would be transferred into in-field tipper trailers commonly used for transporting sugarcane (e.g., units fabricated by Cameco Industries) that self-unload, using tractor auxiliary 
hydraulics, at the edge of the field for consolidated highway transporting, or the harvested material could be transferred directly from the harvester into highway haulers. Because the highway haulers inevitably would spend a significant portion of time waiting for tipper trailers to collect, transport, and transload the harvested material into the trucks, the truck drivers could assist in the operation of tipper trailers as equipment availability and scheduling permit (thereby reducing the labor required for in-field transporting and transloading by one-half).

Figure 6-2 shows field equipment employed in harvesting and transporting banagrass in the ten-acre demonstration on Molokai. Similar harvesting equipment was used to harvest banagrass in a year-long precommercial operation at WSCo in 1997.

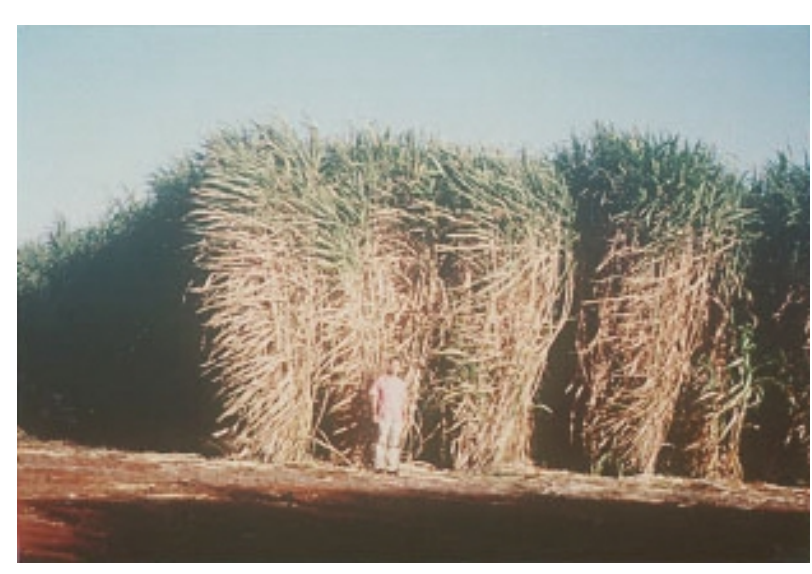

(a) Standing banagrass at harvest.

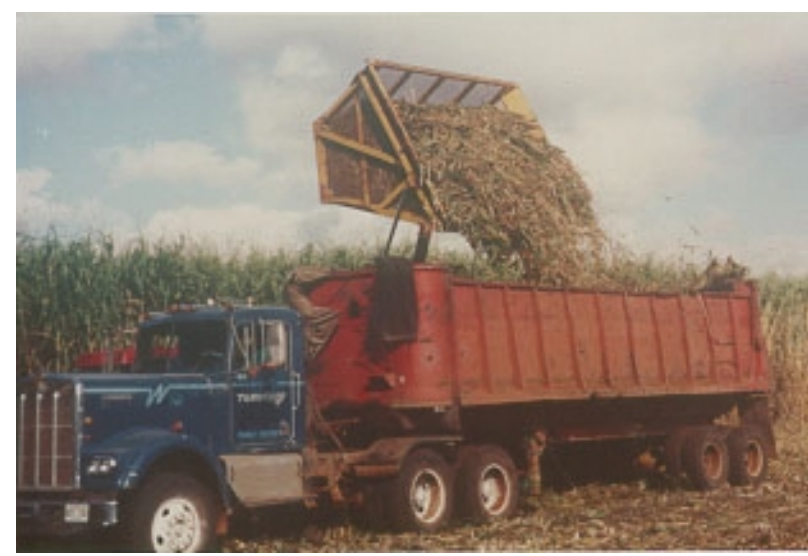

(c) Transloading banagrass from tipper trailer into truck/trailers (with capacities varying from 30 to 45 cubic yards) near field edge for highway transporting.

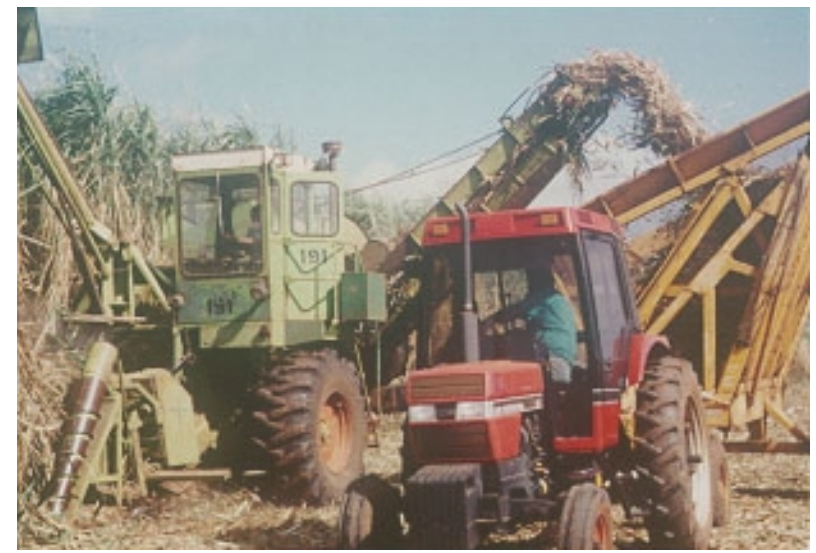

(b) Claas Model CC1400 sugarcane harvester transferring chopped banagrass into Vanguard Model V1248-2 tipper trailer (20 cubic yard capacity) for infield transporting/transloading.

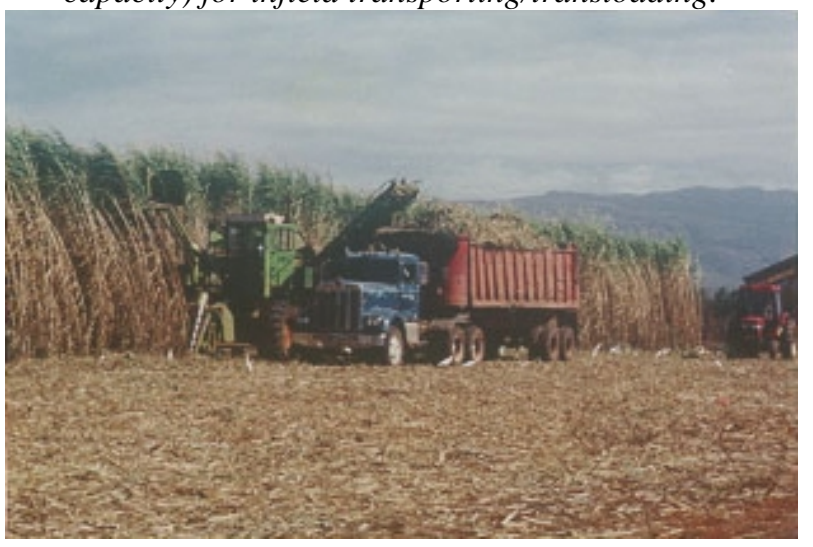

(d) Harvester transferring banagrass directly into truck/trailers.

\section{Fig. 6-2. Field equipment employed in harvesting and transporting banagrass on Molokai.}

It seems likely that single in-field tractors could serve double tipper trailer units, thus reducing labor and equipment requirement, yet maintaining high harvester productivity. Highway-legal double trailers, capable of transporting and unloading chopped banagrass and sugarcane would be used. If the harvested material is transported to the conversion facility immediately after cutting, the moisture content of the feedstock delivered to the conversion facility would be essentially the same as that of the crop at the time of cutting ( $\sim 70 \%$ for banagrass; $\sim 60 \%$ for sugarcane). 
An alternative harvesting system, in which a forage harvester replaces the sugarcane chopper harvester with all other equipment remaining the same, also appears to be viable. Such a system was tested in Texas for harvesting one-year old sugarcane at the Rio Grande Valley Sugar Grower plantation (Mason, 1994). This type of system was also tested on banagrass, sporadically, in 1997 at WSCo. The productivity and recovery of the forage harvester and the properties of the harvested crop appear to be very suitable for ethanol-crop application. The forage harvester would produce finer particles than sugarcane chopper harvesters, yielding higher hauling densities (perhaps $\sim 50 \%$ greater -12 pounds per cubic foot as opposed to 8 pounds per cubic foot for the chopper harvester system). Harvesting costs might increase but transportation costs should be lower. While this type of harvesting approach seems promising, insufficient information exists to determine its feasibility for commercial harvesting of banagrass or sugarcane.

\subsubsection{Other Field Operations}

In addition to the operations described above, other field operations would be needed to support energy-crop production, including road maintenance and soil conservation. Some research and crop logging also should be performed. Certain research functions might be handled by an independent research organization such as the Hawaii Agriculture Research Center (HARC) or by the university's extension service. Some in-house work probably would be performed by a plantation agriculturist, an assistant, and several field workers. Nutrient analysis of crop samples would be taken to monitor growth and nutrient status. The amount of work to be performed by the crop control unit for banagrass probably would be less than for sugarcane.

\subsection{Unit Operations in Tree Crop Production}

Hawaii has been home to nearly two centuries of commercial experience in producing sugarcane which would be directly applicable to growing sugarcane and similar grass crops for ethanol conversion; however, little experience exists in Hawaii in growing tree crops commercially. Numerous studies and demonstrations on establishing and managing short-rotation tree plantations in Hawaii (e.g., Whitesell, et al. (1992), Osgood and Dudley (1993)) have been performed in the last decade. Results from these studies and experience being gained by the recently started Forest Solutions, a Eucalyptus plantation on Hawaii island (Thain, 1999), provide guidelines for tree production in Hawaii. The present investigation examines costs associated with establishing and managing fast-growing trees and the cost of harvesting and transporting trees to a central location for conversion into ethanol.

\subsubsection{Soil Preparation}

The lands selected for tree production are existing or abandoned canelands. The abandoned canelands have been out of crop production for only several months to many years. Recently harvested canelands would be prepared in the manner described for grass crops. On abandoned canelands, heavy rollers would be used to cut and crush cane and other vegetation; this typically requires about 1 hour per acre. If the area is covered with very heavy vegetation and brush, a tractor equipped with a bulldozer blade has to be used. The blade is held about one foot above the ground to knock down heavy brush so that a harrow or roller can crush the material. This additional operation requires about 2 hours per acre. On some lands, a D-6 tractor equipped with wide-gauge shoes is used to pull a heavy-duty, off-set cutaway harrow. This process requires about 0.75 hours per acre. After clearing, herbicide spray may be applied if the vegetation returns before planting. About 0.2 tractor hours per acre is required for this treatment. Tree seedlings are planted about two weeks after herbicide spraying.

\subsubsection{Seedling Production, Planting, and Coppicing}

Eucalyptus planting stock can be produced in a containerized nursery system using plastic dibble tubes and racks (Whitesell et al., 1992). Most Eucalyptus plantation programs utilize container-raised stock. The dibble-tube system has been found to be more reliable and less costly than bare-root stock for 
Eucalyptus in Hawaii (Walters, 1981). This system was adopted for Eucalyptus tree production in a 10-year RD\&D program conducted by BioEnergy Development Corporation on Hawaii island. Plastic dibble tubes called "Ray Leach Cone-tainer Pine Cells," having a volume of 4 cubic inches, are used in this nursery system. The tubes have interior ribs to prevent root spiraling and a hole at the bottom for drainage and air pruning of the roots. The tubes are placed in racks, each holding 200 dibble tubes.

The potting medium is a 2:1 mix of vermiculite and peat moss. The mixture is moistened so that it remains together in the tube. Racks of tubes are filled manually, then jarred on a table to settle the mixture in the tubes. A Plexiglas plate with protrusions for each tube is pressed onto each rack of filled tubes to make indentations for seeds. Seeding is done manually with a mixture of seed and chaff, the mixture depending on germination tests of each seed lot. The seeds then are covered lightly with a layer of fine gravel.

Every other row of tubes is removed and placed in a second rack to give a density of 100 tubes per rack. The racks then are moved to benches in a roofed shadehouse and irrigated several times a day with an automated overhead sprinkler system. Germination occurs in five to seven days. In about four to six weeks, seedlings grow 3 to 4 inches tall and are moved outside of the shadehouse for hardening under full sunlight. The seedlings are ready for outplanting 3.5 to 4 months after sowing, when they are about 12 to 15 inches tall. An alternative method for producing planting stock involves using rooted cuttings from selected outstanding trees in existing plantations. Several years' lead time would be needed to build-up clone banks of superior material. Dramatic improvements in yield may be obtained by selecting and propagating superior clones.

Racks of seedlings in dibble tubes are transported to the field in trucks that are enclosed to minimize exposure to wind. The racks are hand-carried to the planting site and then the tubed seedlings are transferred to planting bags; the seedlings are removed from the tubes just before being placed in the ground. Planting is done manually by two persons. About 600 Eucalyptus seedlings can be planted by a single person per day under Hamakua site conditions (fewer seedlings would be planted in rocky soils). Using this method of propagation and planting, survival typically is $95 \%$ or higher. Planting could be performed with a two-row, tractor-mounted tree transplanter, adjusted for rows spaced 6-7 feet apart. The transplanter, with three workers, should be capable of planting about seven acres per day. Two ounces of N-P-K (16-16-16) fertilizer would be distributed per tree during planting. Under either method of planting, fields should be monitored to identify areas needing replanting.

Management of regrowth (coppice) from the harvested tree stump is necessary to ensure optimal production. This includes thinning the coppice to two to three sprouts per stump and replanting stumps damaged in the harvesting operation. Coppice management would be required after each harvest.

\subsubsection{Fertilization}

Field research trials in Hawaii have demonstrated the importance of nitrogen $(\mathrm{N})$, phosphorus $(\mathrm{P})$, and potassium $(\mathrm{K})$ fertilization on tree growth. Two initial applications of commercial fertilizer would be provided to Eucalyptus in the first year. At planting or soon thereafter, 4 ounces of N-P-K (14-14-14) fertilizer is applied to a dibble hole adjacent to each seedling. A second application is made in a similar fashion six months after planting. The fertilizer is buried in high rainfall areas and broadcasted in arid areas.

Additional fertilizer applications following initial fertilization at planting would increase growth rate and enhance biomass yield. For Eucalyptus, growth increases with increasing N. It is recommended that additional nitrogen fertilizer be applied after planting at rates of 30 pounds at 12 months, 100 pounds at 18 months, 100 pounds at 30 months, and 50 pounds at 42 months. If Leucaena is planted, N, K and $\mathrm{P}$ would 
be required at planting, but only $\mathrm{P}$ and $\mathrm{K}$ would be required after planting as Leucaena is nitrogen fixing. Application rates would be based on soil and tissue analyses, taking yield versus cost into consideration. Fertilization cost for Leucaena should be lower than for Eucalyptus.

\subsubsection{Weed Control}

Young trees do not compete well with weeds, especially in fertile soil. The critical period of development is two to three months after planting, when regrowth of a previous crop (e.g., sugarcane) and other weeds compete with the tree seedlings. Weeds should be kept under control with one application of herbicide prior to planting and two or three applications following planting. Post-planting weed control is done with manual backpack sprayers or using tractor-mounted sprayers. At the early stage, trees are sensitive to herbicide so care should be taken to avoid contact between the herbicide and the young plants. Herbicides used for weed control include glyphosate (Roundup), fluazifop-P (Fusilade), and oxyflurfen (Goal).

If the first herbicide application is performed carefully and in a timely manner, many of the Eucalyptus trees should outgrow weeds within the first six months. A second spot application of herbicide is made five to six months after planting in areas showing significant regrowth of weeds. Typically only about one-half of the area will call for the spot application (the same formulation of glyphosate, surfactant, and antifoam agents would be used). The work typically takes about 3 person-hours per acre. The second fertilizer application can follow herbicide spraying. If the plantation employs $5 \times 5-\mathrm{ft}$ or $6 \times 6-\mathrm{ft}$ spacing of trees, herbicide spraying would cover essentially the entire area and crown closure by the Eucalyptus would minimize the need for weeding after the first year. If wider spacing is used, the first spraying could be confined to circles around the trees large enough to keep them free of competition by weeds. The second spraying might need to control taller vegetation between rows which could interfere with the trees as they grow taller. In windy, dry areas, spraying is often hampered by windy conditions so it might be advantageous to mow the weeds and leave the vegetation on the ground as a mulch to help conserve soil moisture and retard regrowth of weeds.

\subsubsection{Irrigation}

Leucaena is usually planted in areas having low rainfall. The crop would need to be irrigated to produce high yield. Irrigation would be supplied by drip irrigation, in a manner resembling that described earlier for banagrass, except the drip tubing would be selected specifically for tree crops, e.g., similar to those used in Hawaii for macadamia nut trees. The drip tubing would be thick walled with insert emitters or minisprinklers provided for each tree. As with banagrass, only the tubing would have to be replaced on a regular basis (probably after every harvest); the other hardware, largely buried, would last indefinitely (e.g., the submain lines should remain functional for three or four rotations). The amount of irrigation water applied to tree crops is assumed to be 5,000 gallons per acre-day. Irrigation should not be needed for Eucalyptus if the plantation is located in high rainfall areas, such as the Hamakua site on Hawaii island.

\subsubsection{Harvesting and Transporting}

The harvesting operation for trees would be fully mechanized using commercially available equipment. A feller buncher unit, capable of cutting $0.35 \mathrm{~m}$ diameter stems, would be used to harvest standing trees. The stems are sheared at the base using hydraulic shears located at the base of the feller buncher. Clean shearing would be required to minimize stump damage for good coppice regrowth. Following tree felling, skidder/forwarders would collect the felled trees and transport them to centralized infield locations where the trees would be chipped. In-field chipping units would chip the whole trees and discharge the chips into wood chip vans. The chipper accomplishes this by positive feeding of the trees into a rotating flywheel with knives attached. The chip van is enclosed to minimize loss of chips. When the van is full, the trailer would be connected to a hauler that delivers the chips to the conversion facility. Fig. 6-3 
shows an integrated harvesting system which includes a feller, chipper, and other equipment. When the chips are delivered to the conversion plant, they would either be fed directly to the biomass conversion facility or stored for later use.
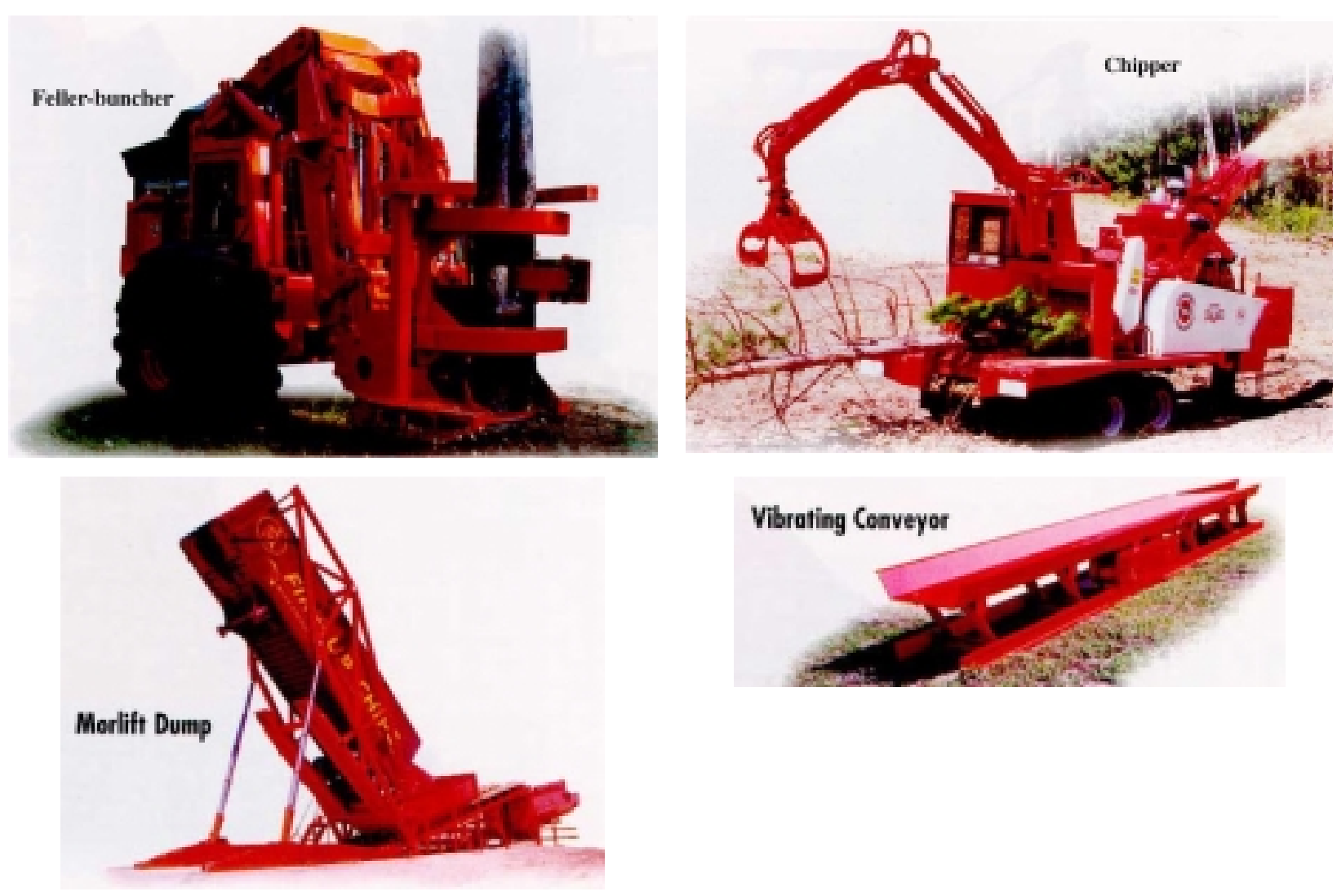

Fig. 6-3. Tree harvest and chipping equipment (Morbark Inc., 1998).

Commercial experience with mechanical harvesting and transporting of intensive-culture trees so far is lacking in Hawaii. A Eucalyptus plantation has been established in Corning, California, by Simpson Timber Company, to produce wood chips and residues. Two harvesting contractors are employed to perform harvesting. One contractor uses feller bunchers, large Cat grapple skidders, and Peterson Pacific DDC systems to process trees. The other contractor uses large front-end loaders and other Morbark equipment to process trees.

An investigation for these two systems (Spinelli and Hartsough, 1999a) indicates that the loader is task-versatile and the skidder is terrain-versatile. A single loader can extract trees and handle the landing duties, such as moving residues from the flail-chipper. It can perform more tasks at a faster pace than the skidder but performs well only in flat, solid terrain. On steep terrain or soft soil, the loader is hampered by its high center of gravity and its poor flotation. The skidder has a wider range of operational capabilities over different terrain, but requires a second machine (small loader) to handle loading functions. Experience shows that the Morbark flail and drum chipper system has 30\% greater output. The Morbark chipper has a large opening which facilitates feeding of crooked stems as they exit the flail (Spinelli and Hartsough, 1999b). Because few studies on using such machines to harvest short-rotation woody crops have been performed, selection of tree harvesting equipment based on local conditions needs further investigation. 


\subsubsection{Other Field Operations}

As with commercial production of grass crops, other field operations in addition to those described above would be needed to support tree production, including road maintenance and soil conservation measures. Some research and crop logging should be performed as well. In-house work could be performed by a plantation agriculturist, an assistant, and several field workers. The work might include field trials, growth measurements, and crop logging. Nutrient analysis should be performed to monitor the nutrient status of the crop.

\subsection{Cost Predictions}

\subsubsection{Cost Predictions for Grass Crop Production}

Production cost for the grass crops, sugarcane and banagrass, were projected largely from actual costs at a large, commercial sugarcane operation in Hawaii. The cost accounting system of the model grower contains about 60 cost centers covering all field operations, equipment and supplies, and administration. In this investigation, the 60 cost centers were distributed over 13 broader cost centers according to their operational characteristics and unit bases. Operations for banagrass are slightly different from those for sugarcane. Costs for sugarcane production were adjusted based on operational differences to estimate costs for banagrass production (the adjustments are described in the footnotes of the tables presented below).

Results of the cost analysis for sugarcane production are presented in Table 6-1. This analysis was based on three years' (1995-1997) financial data from an operating sugar company in Hawaii. Sugarcane production cost, $\$ 85$ per ton dry matter, is the average cost over the three-year period. Use of multiple years' cost data helps to moderate year-by-year variations in cost (although the company's cost of production was relatively stable over the three-year period). In Hawaii, sugarcane is grown for two years before it is harvested. Some growers are shifting (on a trial basis) from a two year crop to a one year crop, which will affect sugarcane production costs. The sugarcane costs in this analysis are based on two-year sugarcane production without ratooning.

As indicated in Section 3.2, banagrass would consist of a plant crop, followed by several ratoon crops. Because the unit operations for banagrass in the plant crop would be similar to those for sugarcane, the unit bases and the associated unit costs for the plant crop of banagrass would be similar to those described above for sugarcane. The unit production costs for the banagrass plant crop were calculated from the unit costs for sugarcane presented in Table 6-1 with some modifications based on operational differences between banagrass and sugarcane. Production costs for banagrass ratoon crops were extrapolated from costs for the banagrass plant crop.

Table 6-2 compares the unit costs in each cost center of the banagrass plant crop versus the ratoon crop. As mentioned in the preceding section, ratoon-crop costs for soil preparation, seed production, and planting are assumed to be nil; weed control costs for banagrass ratoon fields are assumed to be only onehalf the cost for spot application of herbicides in sugarcane plant fields; all other ratoon crop costs are assumed to be the same as the corresponding costs for the banagrass plant crop. The cost of producing the ratoon crop is significantly lower than the plant crop. It is assumed that five ratoon crops of banagrass would be obtained from each planting. The cost of banagrass production (\$ per ton, dry basis) with this combination would be lower than the cost of producing plant crops of banagrass or sugarcane.

In this cost analyses, the harvesting and transporting costs calculated by Kinoshita et al. (1995) assuming standard sugarcane billet-harvester systems, were used to predict the costs for harvesting and transporting banagrass. It is believed that larger sugarcane harvesting systems being investigated by the Hawaiian sugar industry might provide opportunities for some cost savings in harvesting banagrass. Table 
6-3 summarizes the predicted costs for the plant crop, ratoon crop, and plant/ratoon-cycle on a per acre harvested basis, per acre cultivated basis (i.e., per acre of crop land per year), and per ton of dry matter biomass delivered basis.

Table 6-1. Summary of sugarcane production costs per acre-crop harvested and per ton harvested (dry basis), by cost centers.

\begin{tabular}{|llrr|}
\hline & & \multicolumn{2}{c|}{ Cost } \\
Cost Center & Unit Basis & \$/unit & s/acre-crop \\
Soil Preparation/Planting & Acre planted & 506 & 506 \\
Seed Production & Acre planted & 50 & 297 \\
Weed Control & Acre planted & 297 & 971 \\
Irrigation & Acre year cultivated & 486 & 228 \\
Fertilization & Acre year cultivated & 114 & 299 \\
Harvesting & Acre harvested & 299 & 181 \\
Transporting & Acre harvested & 181 & 34 \\
Road Maintenance & Acre year cultivated & 17 & 65 \\
Crop Control/Research & \% of total field & $2 \%$ & 79 \\
Other field & \% of total field & $3 \%$ & 8 \\
Equipment Shop & \% of total field & $0.26 \%$ & 0 \\
Landholding & Acre year cultivated & 0 & 335 \\
G\&A-Field & \% of total field & $11 \%$ & 3054 \\
Total & & & $\mathbf{8 5}$ \\
Total (\$/ton, dry basis) & & & \\
1. \% of total field = cost center/total cost of delivered biomass. & \\
2. Two-year crop; assumed dry matter yield = 18 tons/acre-year. & \\
\hline
\end{tabular}

The estimated cost of delivered biomass billets, FOB plant gate, is $\$ 85$ per ton for sugarcane and $\$ 66$ per ton for banagrass (dry-weight basis). These cost figures include items that often are overlooked in other investigations, e.g., support operations such as road maintenance, crop control, miscellaneous field operations, and general and administrative functions. Missing in this investigation is land rent (e.g., Landholding cost is assumed to be zero in Tables 6-1 to 6-3.). The cost for land rent varies substantially in the State of Hawaii, depending on size, location, use, etc. Land rent in the sugar industry ranges from nil to over $\$ 100$ per acre per year. For costing purposes, a reasonable value for land rent for large ( $\geq 5000$ acres) tracts might range from $\$ 65$ to $\$ 100$ per acre per year. Given the sugarcane and banagrass yields projected here, the cost for land rent would add $\sim \$ 4-6$ to each ton of delivered sugarcane, and $\sim \$ 3-5$ to each ton of delivered banagrass. An alternative, higher land rent cost is obtained using data published by the United States Department of Agriculture (1988), which translates to rent for Hawaiian cane lands costing approximately $\$ 110$ per acre per year (although this figure is grossly higher than actual costs compiled by Hawaii's state agencies).

Because costs for producing sugarcane and banagrass were projected largely from the actual operating costs of a single sugarcane grower, the predicted values reflect efficiencies and deficiencies inherent to the company's sugarcane operations and management. Cost analyses for sugarcane and banagrass productions based on data from other sugarcane growers have been performed by Osgood and 
Dudley (1993), and Kinoshita and Ishimura (1995). The predicted costs for sugarcane and banagrass in these reports are summarized in Table 6-4 along with the results from this investigation. The data show only slight differences among the predicted costs even though the analyses were based on data from different sources.

Table 6-2. Production costs of plant crop and ratoon crop of banagrass, by cost center.

\begin{tabular}{|c|c|c|c|c|}
\hline$\underline{\text { Cost Center }}$ & $\begin{array}{l}\text { Plant Crop } \\
\text { Unit Basis }\end{array}$ & $\frac{\text { Unit Cost }^{1}}{\text { \$/unit }}$ & $\begin{array}{l}\text { Ratoon Crop } \\
\underline{\text { Unit Basis }}\end{array}$ & $\frac{\text { Unit Cost }}{\text { \$/unit }}$ \\
\hline Soil Preparation/Planting & Acre planted & 506 & Acre ratooned & 0 \\
\hline Seed Production ${ }^{2}$ & Acre planted & 25 & Acre ratooned & 0 \\
\hline Weed Control & Acre planted & 297 & Acre ratooned & 30 \\
\hline Irrigation $^{4}$ & Acre year cultivated & 486 & Acre year cultivated & 413 \\
\hline Fertilization ${ }^{5}$ & Acre year cultivated & 148 & Acre year cultivated & 148 \\
\hline Harvesting $^{6}$ & Acre harvested & 146 & Acre harvested & 146 \\
\hline Transporting $^{6}$ & Acre harvested & 118 & Acre harvested & 118 \\
\hline Road Maintenance & Acre year cultivated & 9 & Acre year cultivated & 9 \\
\hline Crop Control/Research ${ }^{8}$ & $\%$ of total field & $1.1 \%$ & $\%$ of total field & $1.1 \%$ \\
\hline Other field & $\%$ of total field & $2.6 \%$ & $\%$ of total field & $2.6 \%$ \\
\hline Equipment Shop & $\%$ of total field & $0.3 \%$ & $\%$ of total field & $0.3 \%$ \\
\hline Landholding & Acre year cultivated & 0 & Acre year cultivated & 0 \\
\hline G\&A-Field & $\%$ of total field & $11.0 \%$ & $\%$ of total field & $11.0 \%$ \\
\hline \multicolumn{5}{|c|}{$\begin{array}{l}\text { 1. Cost of banagrass is based mostly on method used by Kinoshita et al. (1995). } \\
\text { 2. Assumed to be } 50 \% \text { of sugarcane due to reduced seed application (tons applied per acre). } \\
\text { 3. Weed Control cost in ratoon crop assumed to be } 50 \% \text { of spot application cost in plant crop } \\
\text { (which is } ~ 20 \% \text { of total weed control cost for sugarcane plant crop). } \\
\text { 4. Irrigation cost of ratoon crop calculated to be } 15 \% \text { lower due to reuse of tubing } \\
\text { 5. Fertilization cost increased by } 30 \% \text { due to increased materials cost (see Section } 6.1 .4 \text { ). } \\
\text { 6. Cost for Harvesting and Transporting banagrass from Kinoshita et al. (1995). } \\
\text { 7. Cost for Road Maintenance assumed to be } 50 \% \text { of sugarcane due to use of lighter equipment } \\
\text { 8. Crop Control/Research cost is redued by } 50 \% \text { due to reduced scope compared to sugarcane. } \\
\text { 9. \% of total field = cost center/total cost of delivered biomass. }\end{array}$} \\
\hline
\end{tabular}


Table 6-3. Summary of banagrass production costs per acre-crop harvested, per acre-year, and per ton harvested (dry basis), by cost center.

\begin{tabular}{|c|c|c|c|c|c|}
\hline \multirow[b]{2}{*}{ Cost Center } & \multicolumn{3}{|c|}{ \$/acre-crop } & \multirow{2}{*}{$\begin{array}{l}\text { \$/acre-year } \\
\text { Average }\end{array}$} & \multirow{2}{*}{$\begin{array}{r}\$ / \text { ton }^{3} \\
\text { Average } \\
\end{array}$} \\
\hline & $\underline{\text { Plant }}$ & $\underline{\text { Ratoon }}$ & $\underline{\text { Average }}^{1}$ & & \\
\hline Soil Preparation/Planting & 506 & 0 & 84 & 127 & 6 \\
\hline Seed Production & 25 & 0 & 4 & 6 & 0 \\
\hline Weed Control & 297 & 30 & 74 & 111 & 5 \\
\hline Irrigation & 324 & 275 & 283 & 425 & 19 \\
\hline Fertilization & 99 & 99 & 99 & 148 & 7 \\
\hline Harvesting & 146 & 146 & 146 & 219 & 10 \\
\hline Transporting & 118 & 118 & 118 & 177 & 8 \\
\hline Road Maintenance & 6 & 6 & 6 & 9 & 0 \\
\hline Crop Control/Research & 19 & 8 & 10 & 15 & 1 \\
\hline Other field & 47 & 20 & 25 & 37 & 2 \\
\hline Equipment Shop & 5 & 2 & 2 & 4 & 0 \\
\hline Landholding & 0 & 0 & 0 & 0 & 0 \\
\hline G\&A-Field & 199 & 87 & 106 & 158 & 7 \\
\hline Subtotal_Field & 1816 & 791 & 962 & 1443 & 66 \\
\hline $\begin{array}{l}\text { 1. Number of ratoon crop } \\
\text { 2. Age at harvest }=8 \text { mor } \\
\text { 3. Assumed dry biomass }\end{array}$ & 22 tons & $\begin{array}{l}\text { five. } \\
\text { re-year. }\end{array}$ & & & \\
\hline
\end{tabular}

Table 6-4. Comparison of predicted costs for sugarcane and banagrass in different reports.

$\underline{\text { Unit }} \quad \underline{\text { This investigation Osgood, Dudley }}{ }^{1}$ Kinoshita, Ishimura $^{2}$

Sugarcane

$\begin{array}{llrrr}\text { Yield Assumption } & \text { tons/acre-yea } & 18 & 16 & \text { No data } \\ \text { Predicted Cost } & \text { \$/acre-year } & 1527 & 1379 & 1640 \\ & \text { \$/ton } & 85 & 86 & \text { No data }\end{array}$

Banagrass

Number of Ratoons

$\begin{array}{rrr}5 & 6 & 5 \\ 22 & 18 & 21 \\ 1443 & 1293 & 1298 \\ 66 & 72 & 60\end{array}$

$\begin{array}{llrrr}\text { Yield Assumption } & \text { tons/acre-yea } & 22 & 18 & 21 \\ \text { Predicted Cost } & \text { \$/acre-year } & 1443 & 1293 & 1298 \\ & \text { \$/ton } & 66 & 72 & 60\end{array}$

1. Osgood and Dudley (1993).

2. Kinoshita and Ishimura (1995). 


\subsubsection{Cost Predictions for Tree Crop Production}

This section addresses costs associated with the establishment and management of fast-growing trees. The cost centers used for predicting tree production costs follow those used in the cost analyses of grass crops. Costs for site preparation, planting, weed control, irrigation, and fertilization were calculated on a per rotation basis. Costs for harvesting and transportation were determined on the basis of biomass dry weight.

Table 6-5 presents the predicted production costs for Eucalyptus. In this analysis, crop rotation is assumed to be five years long and the projected yield is 45 tons (dry basis) per acre per rotation (averaging 9 tons per acre per year). Five years per rotation is suitable for intensive-culture Eucalyptus grown for energy purposes. The tree spacing would be $10 \mathrm{ftx} 7 \mathrm{ft}$ yielding 620 trees per acre. This dense planting was installed in a large-scale biomass-energy demonstration in Hawaii (Whitesell et al., 1992) and has been adopted by Forest Solutions in its 18,000 acres Eucalyptus plantation located on the Hamakua coast of Hawaii island.

Table 6-5. Predicted Eucalyptus tree production costs per acre harvested and per ton harvested (dry basis), by cost center.

\begin{tabular}{|c|c|c|c|c|}
\hline \multirow[b]{2}{*}{$\underline{\text { Cost Center }}$} & \multirow[b]{2}{*}{$\underline{\text { Unit Basis }}$} & \multirow[b]{2}{*}{$\$ /$ unit $^{2,3}$} & \multicolumn{2}{|c|}{ Predicted Cost $t^{1}$} \\
\hline & & & $\$$ \$unit ${ }^{4}$ & $\$ /$ ton $^{5}$ \\
\hline & & & (in 1997 \$) & (in 1997 \$) \\
\hline Site Preparation & Acre planted & $228^{2}$ & 284 & 6.31 \\
\hline Planting & Acre planted & $117^{2}$ & 146 & 3.24 \\
\hline Weed control & Acre planted & $204^{2}$ & 254 & 5.65 \\
\hline Irrigation & Acre year cultivated & $0^{2}$ & 0 & 0.00 \\
\hline Fertilizer application & Acre year cultivated & $39^{2}$ & 49 & 5.43 \\
\hline \multicolumn{2}{|c|}{ Harvesting and chipping Ton } & $20^{3}$ & 21 & 21.29 \\
\hline Hauling & Ton & $3^{3}$ & 3 & 3.22 \\
\hline Road Maintenance & $\%$ of total field & & 1.12 & 0.60 \\
\hline Crop Control/Resarch ${ }^{6}$ & $\%$ of total field & & 1.06 & 0.57 \\
\hline Other field & $\%$ of total field & & 2.58 & 1.39 \\
\hline Equipment shop ${ }^{6}$ & $\%$ of total field & & 0.26 & 0.14 \\
\hline Landholding & \multicolumn{2}{|l|}{ Acre year cultivated } & 0 & 0.00 \\
\hline G\&A-Field 6 & $\%$ of total field & & 10.98 & 5.90 \\
\hline Total & & & & 54 \\
\hline \multicolumn{5}{|c|}{ 1. Assumes crop age $=5$ years; assumes biomass yield $=9$ tons/acre-year. } \\
\hline \multicolumn{5}{|c|}{\begin{tabular}{|l|l|l|} 
2. In $1990 \$$, Whitesell (1992). & \\
\end{tabular}} \\
\hline \multicolumn{3}{|c|}{ 3. In 1993 \$, Hubbard and Kinoshita (1993). } & & \\
\hline \multicolumn{5}{|c|}{ 4. Calculated using Comsumer Price Index from Quarterly Statistical and Economic } \\
\hline \multicolumn{5}{|c|}{ Report, by DBEDT, State of Hawaii. CPI: 1.24 for 1990 \$ to 1997 \$; } \\
\hline \multicolumn{2}{|c|}{1.07 for $1993 \$$ to $1997 \$$. } & & & \\
\hline \multicolumn{3}{|c|}{ 5. All biomass amounts are given on a dry-weight basis. } & & \\
\hline
\end{tabular}


Costs for site preparation, planting, weed control, and fertilization, presented in Table 6-5, were taken from the cost analysis by Whitesell et al. (1992). Those costs were validated by the field manager of Forest Solutions based that company's experience in large scale Eucalyptus production (Thain, 1998). To date, however, commercial harvesting and transporting of trees has not been performed on a large scale in Hawaii. Jakeway and Dudley performed a cost analysis for tree harvesting and transportation assuming a fully mechanized harvest and delivery system (Hubbard and Kinoshita, 1993). This system included a feller, skidder, and chipper. Trucks would be used to deliver biomass to the ethanol conversion facility. Cost estimates for harvesting and transporting using this system were used in the cost analysis presented in Table 6-5.

A cost analysis based on actual harvesting and transporting practices in another large-scale Eucalyptus plantation in Corning, California, which includes costs of two different harvesting and transporting systems for Eucalyptus, is ongoing and the results are not available at the writing (Hartsough, 1998).

Three methods of regenerating Eucalyptus trees after harvesting are commonly used: natural regeneration, artificial planting, and coppicing (regrowing of stumps). With natural regeneration, there is no control over spacing and risk of regeneration failure could be high. Coppice regeneration is possible, but regeneration by coppicing was unsuccessful in trials in Hawaii due to poor resprouting (Whitesell et al., 1992). Thus, artificial regeneration, which is similar to the plantation establishment practice described in Section 6.2.1 and 6.2.2, is considered in this cost analysis.

The predicted cost for Eucalyptus delivered to an ethanol conversion facility is $\sim \$ 54$ per ton (dry basis), which is lower than that calculated for banagrass and sugarcane. These data include the costs for other support operations and administration, such as road maintenance, crop control/research, equipment shop, and G\&A-field. The predicted costs for those cost centers are based mostly on cost estimates for sugarcane and banagrass production in Hawaii. One reason for the low production cost for Eucalyptus is the lack of irrigation-related costs, a major cost center for irrigated crops such as banagrass and sugarcane. Banagrass and sugarcane can also grow without irrigation in high rainfall sites such as in Hamakua on Hawaii island, but yields would be lower than on irrigated plantations. The predicted cost is applicable only to rainfed Eucalyptus plantations. As in the analysis for grass crops, landholding is not included in the cost estimate. If land rent costs about $\$ 65$ per acre-year, the overall cost would increase by $\sim \$ 7$ per ton.

The estimated cost for producing Leucaena, presented in Table 6-6, is about $\$ 85$ per ton, much higher than for the other biomass species. Costs for most operations in Leucaena production were assumed to be the same as those for Eucalyptus. One important characteristic of Leucaena is its rapid regrowth in ratoon crops. Each planted Leucaena crop can be ratooned several times. In this investigation, three ratoon crops were assumed for each plant crop. The average cost for plant and ratoon crops were based on a 20 year cycle with 5 years' growth in each crop. Cost for weed control in the ratoon crops was assumed to be one-third lower than for the plant crop (Hubbard and Kinoshita, 1993). Experiences in small and large trials in Hawaii suggest that in the targeted areas for Leucaena (typically arid or semi-arid locations), irrigation would be needed to obtain high Leucaena yield. The irrigation water consumption was assumed to be equivalent to $80 \%$ of that for banagrass production in this investigation (Hubbard and Kinoshita, 1993). Fertilization of Leucaena would be lower than for Eucalyptus due to the nitrogen-fixing tree's lower $\mathrm{N}$ requirement. In this investigation, fertilizer application for Leucaena was assumed to be $\$ 80$ per acre per crop less than for Eucalyptus. Costs for Road Maintenance, Crop Control/Research, etc., were assumed to be the same percentages of total field cost as for Eucalyptus production. Overall, the cost for Leucaena production is higher than Eucalyptus production due to high irrigation costs. Clearly, significant saving would accrue if irrigation could be eliminated in growing Leucaena. The landholding cost is not included in the cost estimate shown in Table 6-6. If land rent costs about $\$ 65$ per acre-year, the overall cost for Leucaena production would increase by $\sim \$ 6$ per ton. 
A ready means of reducing the cost of producing each ton of biomass feedstock would be to increase crop yield. Osgood and Dudley (1993) calculated the cost of delivering woodchips from irrigated versus unirrigated tree plantations of two different sizes (5,000 acres and 25,000 acres), having yields varying from 8 to 14 tons per acre per year. The results indicate that the cost for irrigated Leucaena decreases by $27 \%$ as yield increases from 10 tons per acre-year to 16 tons per acre-year.

Table 6-6. Predicted Leucaena production costs per ton harvested (dry basis), by cost center.

\begin{tabular}{|c|c|c|c|c|c|c|}
\hline \multirow[t]{2}{*}{$\underline{\text { Cost Center }}$} & \multirow[t]{2}{*}{$\underline{\text { Unit Basis }}$} & $\underline{\text { Plant }}$ & $\underline{\text { Ratoon }}$ & $\underline{\text { Average }}^{1}$ & \multicolumn{2}{|c|}{$\underline{\operatorname{Cost}}^{2}$} \\
\hline & & \$/unit & \$/unit & \$/unit & year & $\$ /$ ton \\
\hline Soil Preparation ${ }^{3}$ & Acre planted & 284 & 0 & 71 & 14 & 1.42 \\
\hline Planting/Ratooning & Acre planted & 146 & 0 & 36 & 7 & 0.73 \\
\hline Weed Control ${ }^{4}$ & Acre planted & 254 & 170 & 191 & 38 & 3.81 \\
\hline Irrigation $^{5}$ & Acre year cultivated & 428 & 364 & 380 & 380 & 37.96 \\
\hline Fertilizer application & Acre year cultivated & 33 & 33 & 33 & 33 & 3.29 \\
\hline Harvesting and chipping & Ton & 21 & 21 & 21 & 213 & 21.29 \\
\hline Hauling $^{7}$ & Ton & 3 & 3 & 3 & 32 & 3.22 \\
\hline Road Maintenance & $\%$ of total field & 1.12 & 1.12 & 1.12 & 10 & 0.96 \\
\hline Crop Control/Resarch ${ }^{8}$ & $\%$ of total field & 1.06 & 1.06 & 1.06 & 9 & 0.91 \\
\hline Other field & $\%$ of total field & 2.58 & 2.58 & 2.58 & 22 & 2.2 \\
\hline Equipment shop ${ }^{8}$ & $\%$ of total field & 0.26 & 0.26 & 0.26 & 2 & 0.22 \\
\hline Landholding & Acre year cultivated & 0 & 0 & 0 & & 0.00 \\
\hline G\&A-Field ${ }^{8}$ & $\%$ of total field & 10.98 & 10.98 & 10.98 & 94 & 9.38 \\
\hline Total & & & & & 854 & \\
\hline
\end{tabular}

1. Number of coppice crops per plant crop $=$ three.

2. Assumes crop age $=5$ years; assumes biomass yield $=10$ tons/acre-year; all weights of biomass are given on a dry-weight basis.

3. Assumed equivalent to cost for Eucalyptus production.

4. Assumed equivalent to cost for Eucalyptus plant crop; one-third less for coppiced crops.

5. Assumes water consumption equals $80 \%$ of that for banagrass production.

6. Assumed equal to cost for Eucalyptus production less $\$ 16$ per acre-year due to lower $\mathrm{N}$ requirement.

7. Assumed equal to cost for Eucalyptus production.

8. Assumes equivalent percentage of total field as in sugarcane production. 


\section{Case Study 1 - Former Waialua Sugar Company Site}

In Section 4, three sites were selected from seven candidate sites based on their suitability for ethanol-crop production. Details on location, agronomic conditions, infrastructure, suitable crops, and feedstock supply potential at one of the three sites selected, Waialua Sugar Company (WSCo), are presented in this section. Agricultural residues and other solid wastes to supplement or replace the dedicated ethanol crop are also discussed.

\subsection{General Description}

Waialua Sugar Company, located near the north shore of the island of Oahu (Fig. 7-1 and Fig. 7-2), operated between 1899 and 1996. Following its first 300 acre sugarcane crop (1700 tons of sugar) in 1899, WSCo grew to become one of the larger sugar producers in the State, reaching peak production in the mid 1970 s of approximately 80,000 tons of sugar per year. WSCo averaged nearly 60,000 tons of sugar annually, from 5,300 acres harvested per year, off 12,000 cultivated acres. Approximately one-half of the 12,000 acres that it farmed in the 1990s is owned by WSCo; the other half is owned by the Bishop Estate.

Sugarcane was grown on more than 120 fields at WSCo, varying in size from $<10$ acres to $>300$ acres (averaging $\sim 100$ acres). These included large tracts in the northeastern section of the plantation, Waimea, Kawailoa, Opaelua, and Helemano, and smaller tracts in the southwestern section, Paalaa, Mill, Valley, Kemoo, Ranch, Gay, and Kawaihapai. The eastern section of WSCo was bordered by pineapple grown by Dole Fresh Fruit Company. Because of the close proximity of the sugarcane and pineapple operations, and because both agricultural entities, WSCo and Dole Fresh Fruit Company, were subsidiaries of the same parent company, Dole Food Company, the line of demarcation between sugarcane and pineapple drifted back and forth frequently.

About $85 \%$ ( 10,400 acres) of the caneland at WSCo was irrigated; the remaining $15 \%(\sim 1,600$ acres), mostly in the northeastern section of the plantation, was unirrigated. Yields of cane and sugar varied throughout the plantation (Fig. 7-3), being highest in drip-irrigated fields in the northern section, lower in the southwestern section irrigated by millwater (i.e., the effluent from the sugar factory's cane-cleaning plant), and lowest in the northeastern, unirrigated fields (Kinoshita and Ishimura, 1995).
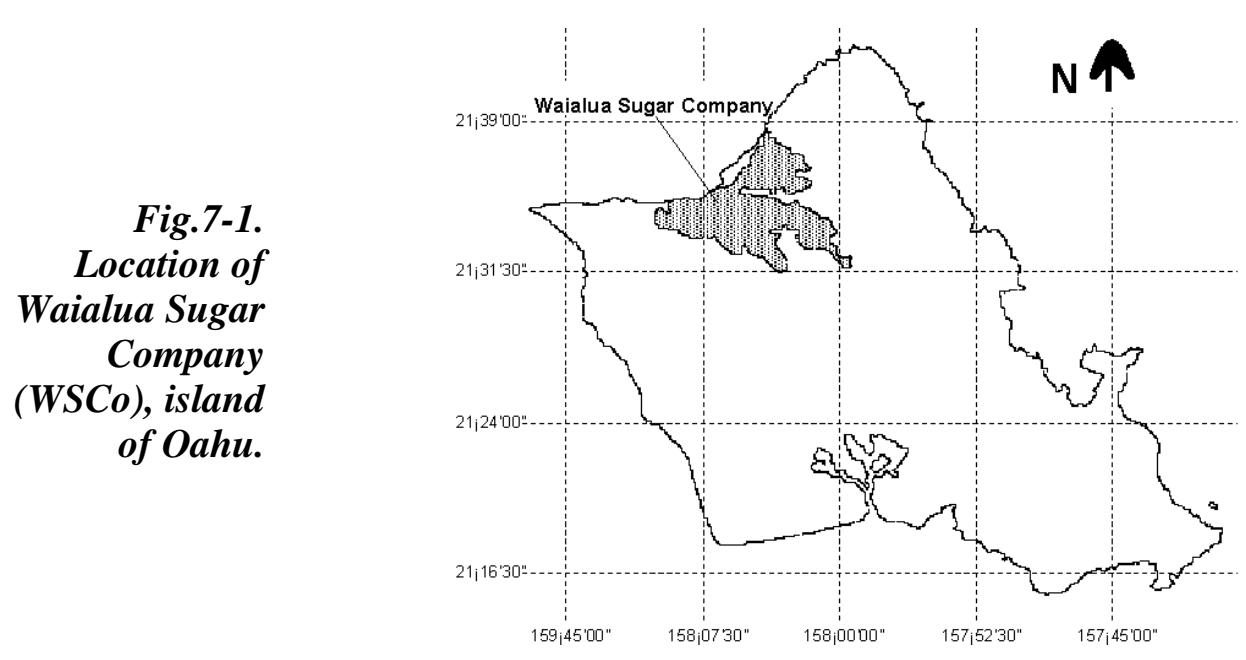
Fig.7-2.

Waialua Sugar

Company,

sugarcane field

designations,

and

surrounding

pineapple

fields.

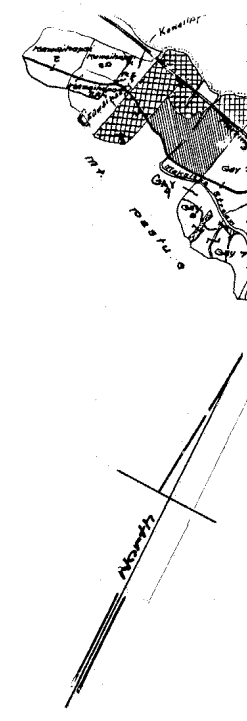

WAIALUA SUGRR CO INC.
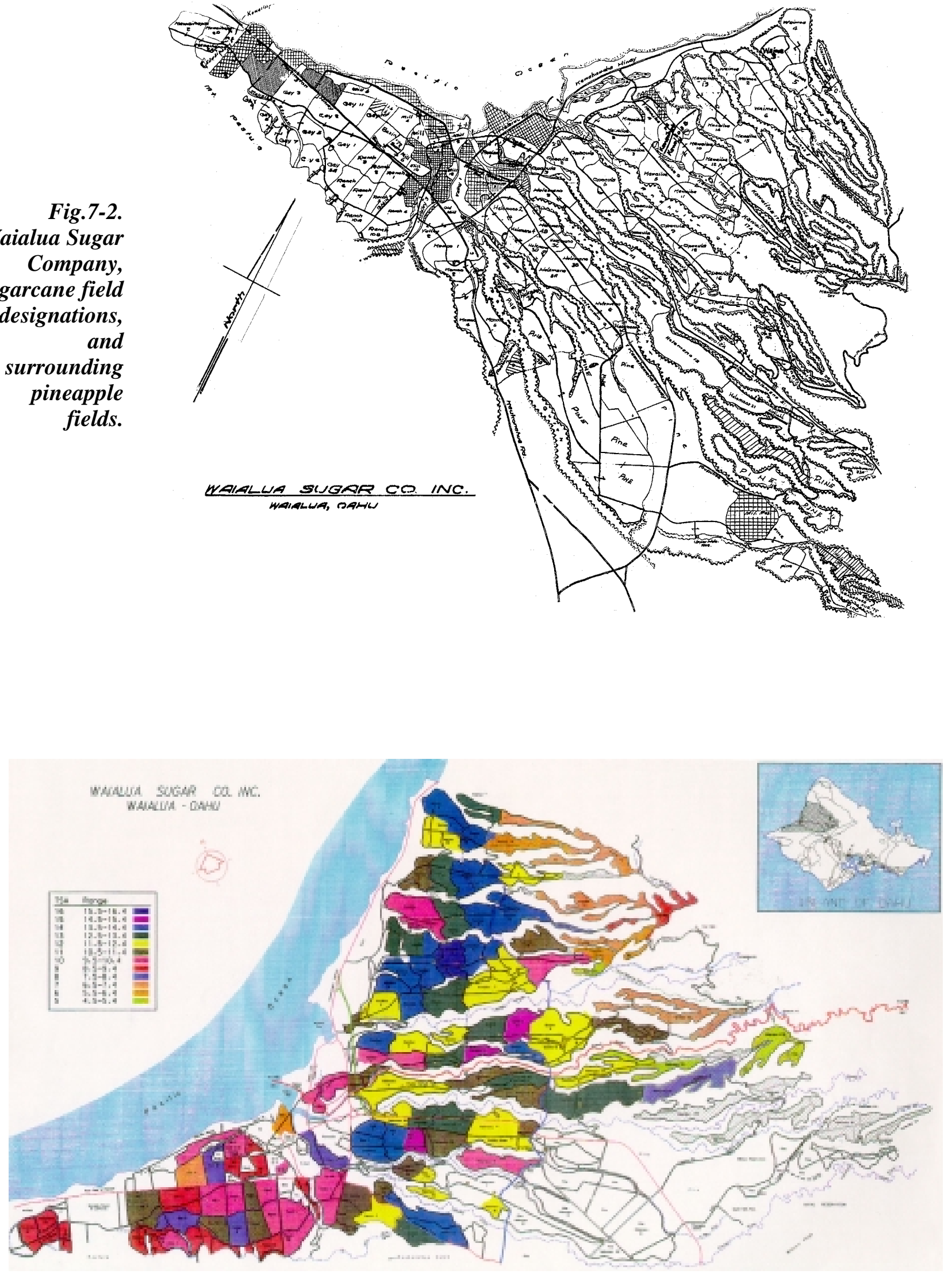

Fig.7-3. Average sugar yield (tons sugar/acre per crop), by field, at WSCo. 


\subsection{Agronomic Conditions}

\subsubsection{Climate}

The island of Oahu has a mild, subtropical climate, with minimal variation in seasonal temperature. Seasonal temperatures rarely deviate $\pm 10^{\circ} \mathrm{F}$ from the mean annual sea-level temperature of $75^{\circ} \mathrm{F}$; mean temperatures $\left(71\right.$ to $75^{\circ} \mathrm{F}$ ) decrease approximately $3^{\circ} \mathrm{F}$ for every 1000 -foot increase in elevation (University of Hawaii, 1972).

The median annual rainfall for agricultural lands farmed by WSCo ranges from 15 to 60 inches (University of Hawaii, 1972). The majority of lands south of Helemano Stream have a median annual rainfall of 15 to 40 inches, while lands north of Helemano Stream and south of Kawailoa Stream receive annual rainfall in the range of 25 to 60 inches. Because high-yielding grass crops require water application rates of $\sim 100$ inches per annum or higher, it is most likely that the vast majority of the land farmed by WSCo would need to be irrigated to produce acceptable yields of ethanol feedstock.

Agricultural lands at WSCo receive relatively high insolation rates of 420 to 500 langleys (calories per $\mathrm{cm}^{2}$-day), with inland areas having lower insolation than coastal areas. Provided that adequate water supplies are available, higher insolation rates translate to higher crop yield.

\subsubsection{Topography}

Lands with slopes below $10 \%$ are more suitable than steeper terrain for irrigation, mechanical cultivation, and harvesting. The majority of lands farmed by WSCo have slopes below 10\%; a few areas, generally farther inland and closer to the Koolau mountain range (north of Helemano Stream), have slopes between 11 and 20\% (University of Hawaii, 1972). Field equipment for sugarcane and banagrass production should not have much difficulty negotiating the terrain upon which sugarcane was grown at WSCo.

Land cultivated by WSCo have two major elevation classifications. Lands south of Helemano Stream are relatively low lying, <300 feet in elevation. In general, lands farther from the coastline increase in elevation, ranging from 150 to 1,200 feet. A number of reservoirs are located at higher elevations, approaching 2,000 feet. Most of the biomass crops can be irrigated by gravity using water supplied from higher lying reservoirs. Locations of high-elevation reservoirs, mostly in the Opaeula and Kawailoa sections, are shown in Fig. 7-4.

\subsubsection{Soil}

Soil on lands farmed by WSCo are classified as Alfisols, Vertisols, Mollisols, and Entisols. The coastal area extending from Mokuleia to Waimea have Entisols soil. Entisols are soils with little or no horizon development, and can be formed from any type of parent materials. Entisols are used in agriculture; however, their suitability depends on location, water supply, texture, and accessibility (McCall, 1973).

The majority of the lands extending inland, adjacent to the aforementioned coastal region, are classified as Mollisols. Soils in a smaller tract of land lying east are of the Vertisols order. Mollisols are deep (>30 inches) soils, having granular or crumb-like structures, and are fine- to moderately-fine-textured, and well-drained. These soils, high in base saturation, are dark or red in color with a mollic epipedon high in organic matter. Mollisols have good natural fertility (varying with weather conditions) and do not harden when dry; therefore, they are excellent for agriculture (University of Hawaii, 1972). Vertisols, on the other hand, have poor structure and tend to crack severely during dry periods. In addition, the shearing and shrinking characteristics of these soils make them less suitable for farming and infrastructure development (United States Department of Agriculture Soil Conservation Service, 1972). 


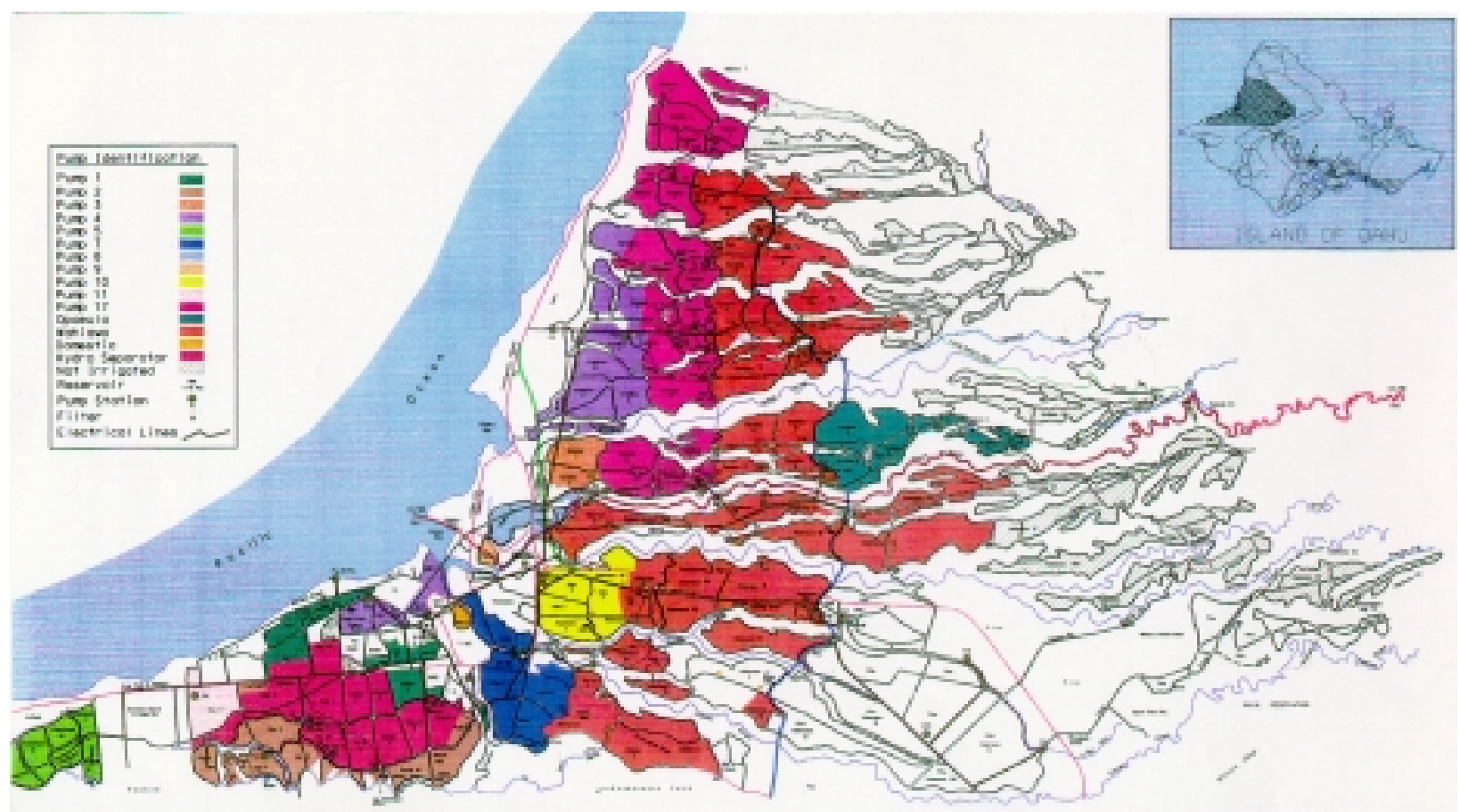

Fig. 7-4. Water distribution system, by pump or source, at WSCo.

Soils farther east and immediately south of the areas containing Mollisols and Vertisols are classified as Alfisols. Alfisols, red in color with moderate to high base saturation, are characterized as having an accumulation of clay in the subsurface. These mineral soils are known to be capable of storing sufficient moisture to sustain plant growth for three months or more, and if irrigated, they can be highly productive (McCall, 1973).

A soil survey identified 22 different soil series on lands farmed by WSCo. The names and locations of these soils are presented in Fig. 7-5.

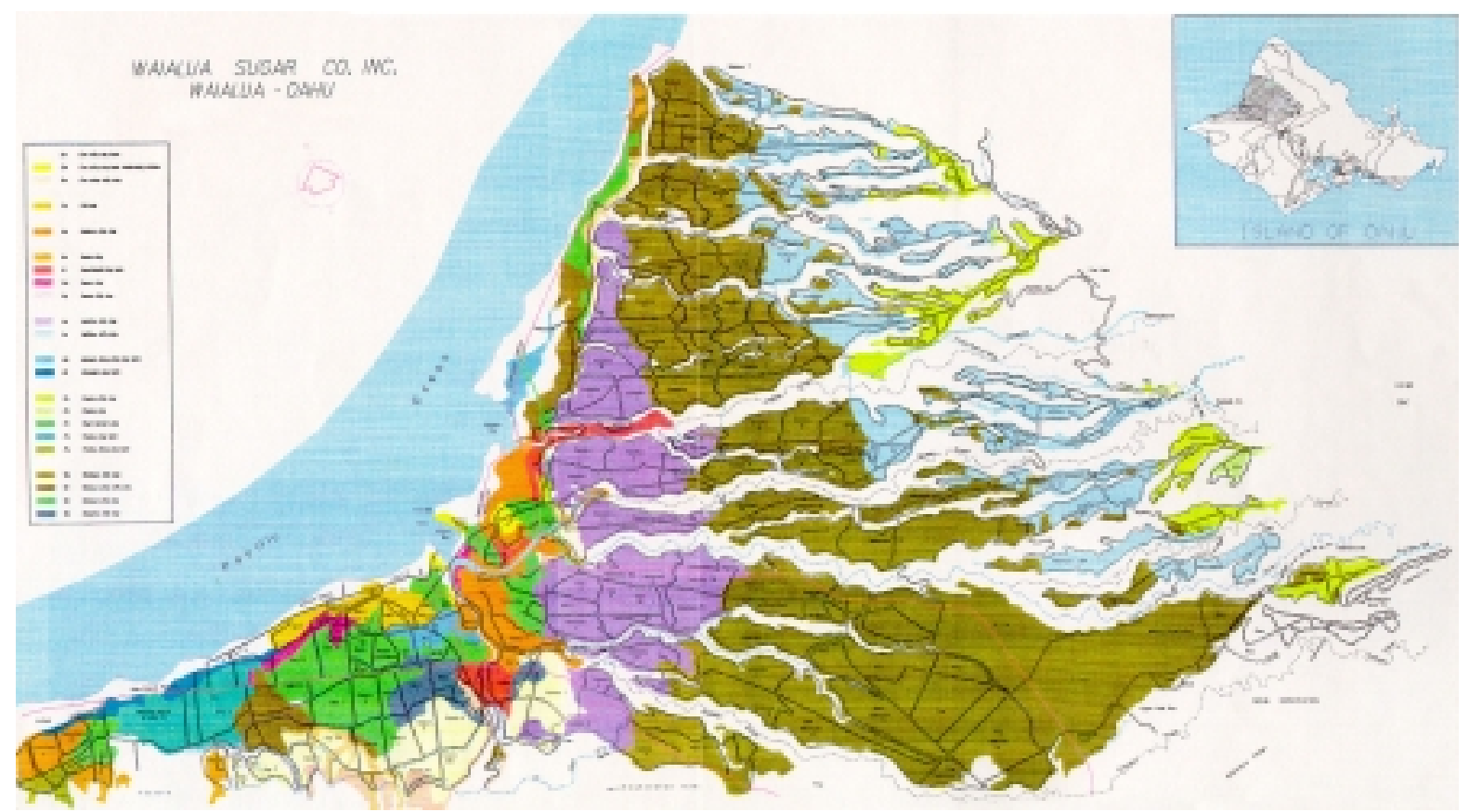

Fig. 7-5. Distribution of soil type, by soil series, at WSCo. 
The two most prominent soil series are the Lahaina and Wahiawa silty clays. Lahaina silty clays are characterized as having moderate permeability, slight to moderate erodability, and slow to medium runoff. These soils have medium acidity and 1.3 inches per foot of available water capacity in the surface layer, and slight to medium acidity and 1.4 inches per foot of available water capacity in the subsoil (United States Department of Agriculture Soil Conservation Service, 1972). Wahiawa silty clays have moderately rapid permeability, slow to medium runoff, and slight to moderate erodability. Available water capacities and acid levels are comparable to Lahaina silty clays; however, the subsoil may be neutral in acidity.

\subsection{Water Supply at WSCo}

All of the Hawaiian islands experience the full range of constraints and advantages associated with the availability of freshwater sources. Success of traditional Hawaiian civilization depended significantly on the allocation of water. The island of Oahu has roughly one million resident population and is the location of most economic activities in Hawaii. Oahu's total water consumption in 1988 was 408 million gallons per day (mgd). Sugarcane production used about $44 \%$ of the total water consumed on the island (with WSCo using about $17 \%$ of the total). Thirty-seven percent of the total water consumption was delivered by the City and County's Board of Water Supply (BWS). Roughly 60\% of the water from BWS goes to residential users, and $25 \%$ to commercial, industrial, and hotel users. The remainder goes to various government units (Moncur, 1994). Water sources and consumption on Oahu in 1985 and 1995 are presented in Table 7-1.

As the sugar industry on Oahu started to decline in the 1980s and ceased in the mid 1990s, water consumption decreased steadily. Domestic water consumption in 1995 also decreased since 1985. Establishment of the State Water Resources Management Commission, which is charge with setting water conservation, quality, and use policy to protect the State's water resources, and with regulating water use (Moncur, 1994), has promoted more efficient utilization of water resources. As water consumption decreases on the island, the water sources and supply systems, especially those established for agricultural use, have achieved excess capacity that can be used to support other economic activities.

The primary water resources on Oahu are groundwater and surface water. Drilled wells, infiltration galleries, and drainage tunnels are the most common ways to access groundwater. More than a thousand deep wells have been drilled on Oahu (University of Hawaii at Hilo, 1998). Most of the drilled wells, ranging between 1 and 2 feet in diameter, are equipped with pumps rated at 1 to $2 \mathrm{mgd}$. Groundwater source capacity on Oahu is about $465 \mathrm{mgd}$ and the withdrawal capacity (mostly from wells) is about $375 \mathrm{mgd}$. Because only about $228 \mathrm{mgd}$ was consumed in 1995, the groundwater withdrawal system has an excess capacity of about $100 \mathrm{mgd}$.

WSCo is about 30 miles from central Honolulu. Roughly $85 \%$ (10,400 acres) of the 12,000 acres of caneland at WSCo was irrigated by a water distribution system that was developed largely by WSCo and was considered to be one of the best in the Hawaiian sugar industry (Fig. 7-4). Both groundwater and surface water were used for cane field irrigation at WSCo. The water supply capacity and water consumption for sugarcane production at WSCo are presented in Table 7-2. About one-half of the irrigation water at WSCo comes from surface water sources and the remainder from groundwater sources. The total capacity of surface water and groundwater sources is about $125 \mathrm{mgd}$. Irrigation water consumption at WSCo was about $70 \mathrm{mgd}$ for 12,000 acres of sugarcane production. The supply of water at WSCo should be sufficient to support ethanol-crop production on 12,000 acres.

In the Hawaiian islands, groundwater exists mainly as basal water that floats on seawater, or highlevel water remote from seawater. Most of the available groundwater on Oahu is basal water. The Waialua basal-water body underlies an area of about 18 square miles on the north shore of the island. The volume of basal water in storage is estimated to be 140 billion gallons. About 70 million gallons per day can be pumped from this groundwater source if efficient water development methods are used (Dale, 1978). 
Wahiawa Reservoir is operated by Wahiawa Water Company, a wholly owned subsidiary of WSCo's parent company, Dole Food Company. One system, called the Waialua Flume, was used for field irrigation and significantly improved labor efficiency at WSCo (Wilcox, 1996).

Approximately 7,400 acres ( $70 \%$ of the irrigated acreage) are irrigated with Wahiawa mountain water containing some level of sewage effluent. Sewage effluent discharged into Wahiawa Reservoir is treated to the secondary level, which calls for the removal of solids and harmful bacteria (beneficial bacteria are left in to break down the waste water). WSCo's use of water in the reservoir is crucial to the lake's viability, as the withdrawal of water for irrigation helps to stir-up and flush nutrients. Significant reduction or ceasing of this practice may disrupt the nutrient balance of the reservoir (Infante, 1993). Approximately 95\% of the lake's nutrients comes from sewage effluent discharged into the reservoir. It has been projected (Waialua Sugarcane Company, 1994) that if sewage effluent increases proportionately with population (which was projected to increase by $46 \%$ between 1980 to 2010), the amount of discharge from the Schofield Wastewater Treatment Plant will increase from $2.7 \mathrm{mgd}$ to $3.9 \mathrm{mgd}$ and the amount from the Wahiawa Wastewater Treatment Plant will increase from $2.0 \mathrm{mgd}$ to $2.9 \mathrm{mgd}$.

Treated sewage effluent has been used in conjunction with ditch water to irrigate sugarcane fields in Hawaii for many years. Increased cane yields have been documented when the combined water resource is managed effectively. Nutrient analyses of the effluent from Wahiawa Sewage Treatment Plant and of the water at the irrigation withdrawal in the Wahiawa Reservoir (Schmitt, 1973; Ekern, 1975) indicate that the levels of primary nutrients (N, P, and $\mathrm{K}$ ) in the sewage effluent are quite high, in some instances exceeding $10 \mathrm{mg}$ per liter. Such concentrations sufficient to satisfy much or all of the nutrient requirements of highyielding energy crops. However, if the sewage effluent is diluted with large amounts of nutrient-free water, levels of nutrient applied to the field would be on the order of 10 pounds per acre-year, much less than the $\sim 200$ pounds per acre-year needed by most ethanol crops. In keeping with WSCo's former practice of ignoring sewage-effluent-nutrients in determining fertilizer application rates, in this investigation, the sewage effluent was ignored in assessing the fertilizer requirements for ethanol-crop production and in the cost projections.

\subsection{Transportation at WSCo}

Hawaii's transportation network differs from that of the other 49 states in the nation. It is the only state that relies entirely on air or sea transport for all exports and imports. A transportation map for Oahu is presented in Fig. 7-6 (State of Hawaii, 1995b). Oahu's efficient highway system provides quick and easy access to all areas of the island. Three freeways, H1, H2, and H3, and several other major highways on the island form the ground transportation network. All three of the freeways were built and are maintained by the State. The State built and maintains Kamehameha Highway and Farrington Highway which run across the Waialua area and are connected to H2. Built and maintained by the Honolulu City and County, Kaukonahua Road is another major road in the Waialua area that connects the area to Farrington Highway. Most of the County roadways service the rural homestead communities that are scattered throughout the Waialua area.

The freeway network on the island and the road system in the Waialua district make ground transportation efficient from this district to any other location on the island. Table 7-3 presents the major highways and freeways in the Waialua area and on the island. The distance from Waialua to the airport or the two major commercial harbors on the island is less than 30 miles via highway. Because Waialua is located on the northwest section of the island and is remote from Honolulu, the volume of traffic in Waialua is low. Ground transportation from Waialua to the airport or the harbors does not pass through Honolulu's heavy traffic. 
WSCo owns and maintains a substantial network of private agricultural roads including a broad, paved, cane haul system that runs from the fields to the location of the former sugar mill. This road network, shown in Fig. 7-2, provides adequate infrastructure to transport harvested biomass from fields to any location in the Waialua area. The 120 fields at WSCo are connected through this road network to the former sugar mill. Because ethanol-crop cultivation is similar to sugarcane production, this road network should be highly suitable for ethanol-crop production.

Virtually all (98.6\%) imported food, building materials, manufactured goods, and energy products in the State arrive by sea. There are two commercial deep-draft ports on Oahu, Honolulu Harbor and Barbers Point Harbor. The Honolulu waterfront is the heart of commerce in Hawaii. A world class port, Honolulu Harbor is the largest and most important harbor in the State. Imported crude oil and petroleum products are off-loaded at Barbers Point Harbor. These two ports have basin depths exceeding 35 feet, heavy lift capacities, and transit shed facilities (Table 7-4). Honolulu Harbor also has facilities for containerized cargo (Barbers Point Harbor is scheduled to receive expanded cargo facilities). WSCo is about 25 miles from either Honolulu Harbor or Barbers Point Harbor.

A disadvantage of ocean transportation for Hawaii is cost. The Merchant Marine Act of 1920, commonly called the Jones Act, requires that passengers and cargo traveling from one port to another within the United States must be carried by vessels built and registered in the United States, as well as owned and operated by U.S. citizens. Traffic between Hawaii and the mainland is covered by this legislation, causing shipping costs to be higher than if trade were open to foreign companies.

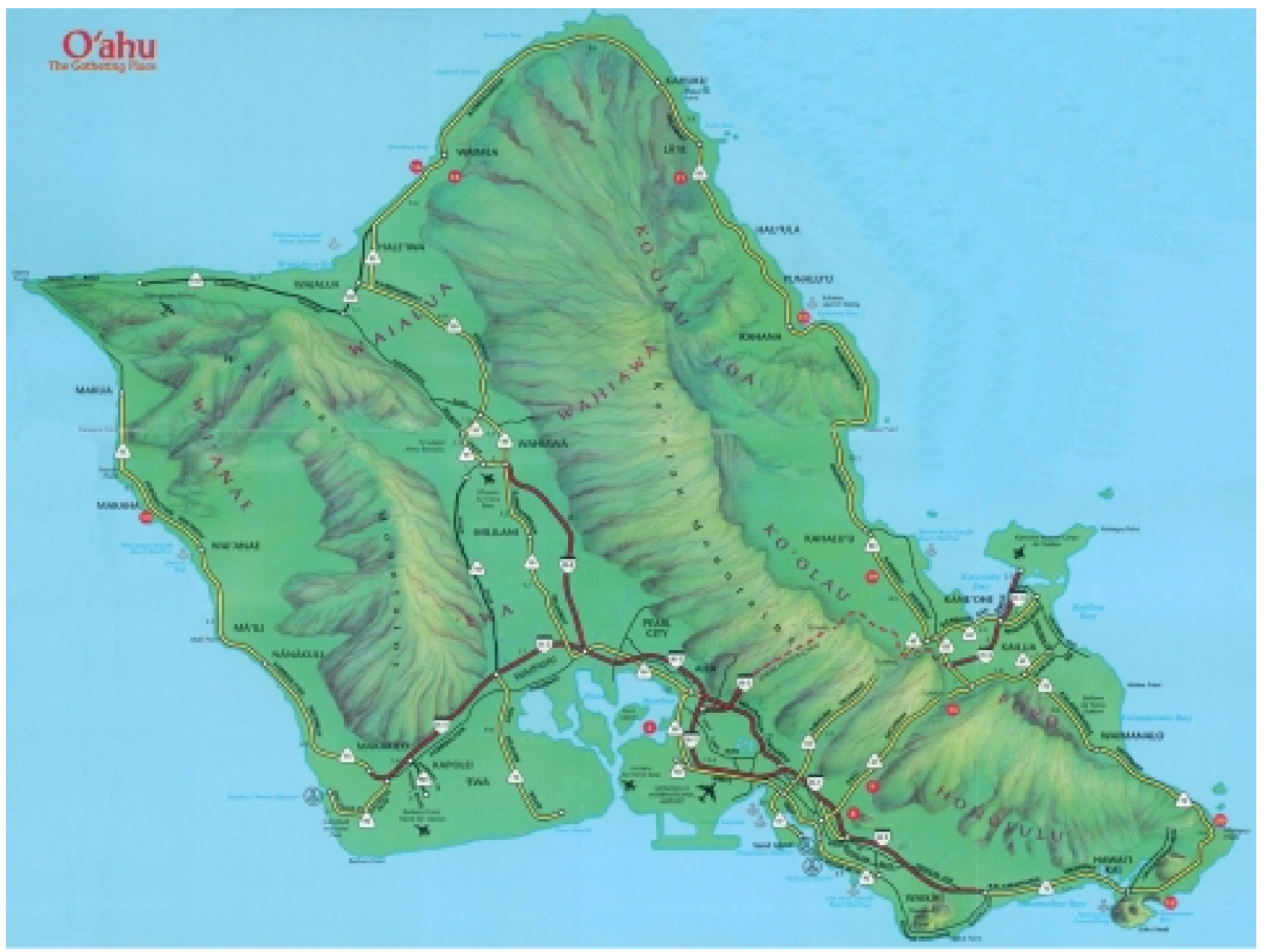

Fig. 7-6. Transportation on the Island of Oahu. 
Table 7-3. Ground transportation conditions in the Waialua area.

\begin{tabular}{|c|l|c|}
\hline Road & \multicolumn{1}{|c|}{ Linkage } & \\
\hline Highway & \multicolumn{1}{|c|}{} \\
\hline Kamehameha Highway & Across Waialua area. & \\
\hline Frarrington Highway & Across Waialua area. & \\
\hline Kaukonahua Road & Across Waialua area. & \\
\hline Freeway & & \\
\hline H1 & Expressway system, which connects airport, \\
\hline H2 & harbors, and other areas to Waialua \\
\hline H3 & district via Kamehameha Highway. \\
\hline Ground Transportation & & \\
\hline From & To & Distance \\
\hline Waialua & Honolulu Airport & (miles) \\
\hline Waialua & Honolulu Harbor & 22 \\
\hline Waialua & Barbers Point Harbor & 28 \\
\hline
\end{tabular}

Table 7-4. Commercial harbors on Oahu island.

\begin{tabular}{|c|c|c|c|c|c|c|c|}
\hline \multirow[t]{2}{*}{$\underline{\text { Harbor }}$} & \multirow{2}{*}{$\frac{\text { Entrance }}{\frac{\text { Depth }}{\text { (feet) }}}$} & \multicolumn{3}{|c|}{ Harbor basin } & \multicolumn{3}{|c|}{$\underline{\text { Storage area }}$} \\
\hline & & $\frac{\text { Depth }}{\text { (feet) }}$ & $\frac{\text { Length }}{\text { (feet) }}$ & $\frac{\text { Width }}{\text { (feet) }}$ & (linear feet) & $\frac{\text { Shedded }}{(1,000 \mathrm{~s}}$ & $\frac{\text { Open }}{\text { are feet) }}$ \\
\hline Honolulu & 45 & & & & 29308 & 1380 & 8460 \\
\hline Main & & 40 & 3300 & 1520 & & & \\
\hline Kapalama & & 40 & 3400 & 1000 & & & \\
\hline Barbers Point & 42 & 38 & 2100 & 1800 & 1860 & - & 1647 \\
\hline
\end{tabular}

Air transportation is another important conduit to Hawaii. Honolulu International Airport provides services for 23 million passengers per year and about $2 \%$ of the imported goods. In 1994, there were 33 overseas air carriers linking Hawaii with major cities in the world. Honolulu International Airport is the fifteenth busiest airport in the nation. The major islands of the State are linked by an airline network that claimed four of the twenty five busiest city-pair markets in the nation in 1994. Two airlines, Hawaiian Airlines and Aloha Airlines, are the dominant airlines that provide scheduled inter-island air carrier service between the major islands.

\subsection{Power Supply at WSCo}

In the State of Hawaii, about $30 \%$ of the raw energy sources is used for electricity generation. Owing to moderate weather conditions and high electricity price, Hawaii residents use less electricity per capita, $5.7 \mathrm{kWh}$ per person per day, than any other state in the U.S. In the State, electric utilities and major gas utilities are regulated by the Public Utilities Commission (PUC). Hawaiian Electric Company, Inc. (HECO), a subsidiary of Hawaii Electric Industries, Inc. (HEI), provides utility electricity service on Oahu. In 1994, HECO sold 6,796 GWh of electricity and earned \$657 million in revenue. HECO's own generators produced $4,236 \mathrm{GWh}$, or $58 \%$, of the $7,222 \mathrm{GWh}$ generated for utility distribution. The remainder was 
produced and sold to the utility by other generators for redistribution by the utility company. Table 7-5 summarizes electrical generation capacity on Oahu in 1994.

The utility electricity system on Oahu currently has a firm capacity of 1,669 MW. HECO owns 1,263 MW, or 57\% of that capacity. A system peak of $1220 \mathrm{MW}$ was reached in 1997 (State of Hawaii, 1998b). Presently, electricity generation capacity is sufficient to meet demand. The average price for electricity was about $\$ 0.13$ per $\mathrm{kWh}$ for residential and about $\$ 0.10$ per $\mathrm{kWh}$ for other users in 1997 , about 73\% higher than in 1988. Table 7-6 summarizes electricity consumption and prices on Oahu.

Table 7-5. Electrical generation capacity on Oahu ${ }^{I}$.

\begin{tabular}{|c|c|c|c|}
\hline$\underline{\text { Owner }}$ & $\underline{\text { Fuel }}$ & Mode of Operation & $\frac{\text { Capacity }}{\text { (MW) }}$ \\
\hline $\mathrm{HECO}$ & LSFO & Firm Baseload & 835 \\
\hline HECO & LSFO & Firm Cycling & 326 \\
\hline HECO & Diesel & Firm Peaking & 102 \\
\hline Kalaeloa Partners & LSFO & Firm Baseload & 180 \\
\hline AES Barber Point & Coal & Firm Baseload & 180 \\
\hline H-Power & MSW & Firm Baseload & 46 \\
\hline & & Firm Capacity Subtotal & 1669 \\
\hline BHP Refinery & Refinery Gases & Non-Firm & 18 \\
\hline Chevron Refinery & Refinery Gases & Non-Firm & 9 \\
\hline Kapaa Partners & Landfill Methane & Non-Firm & 3 \\
\hline Makani Uwila & Wind & Non-Firm & 5 \\
\hline & & Non-Firm Capacity Subtotal & 35 \\
\hline & & Oahu Capacity Total & 1704 \\
\hline
\end{tabular}

Table 7-6. Electricity consumption and price on Oahu.

\begin{tabular}{|c|c|c|c|c|c|c|c|}
\hline \multirow[t]{3}{*}{$\underline{\text { Island }}$} & \multicolumn{3}{|c|}{$\underline{\text { Power Consumption }}$} & \multirow{2}{*}{\multicolumn{2}{|c|}{$\frac{\text { Average Annual Use }}{(\mathrm{kWh} / \mathrm{user})}$}} & \multirow{2}{*}{\multicolumn{2}{|c|}{$\frac{\text { Average Rate }}{(\$ / \mathrm{kWh})}$}} \\
\hline & \multirow[b]{2}{*}{$\underline{\text { Total }}$} & \multirow{2}{*}{\begin{tabular}{c|}
$(\mathrm{GW})$ \\
Residential \\
\end{tabular}} & \multirow[b]{2}{*}{ Other } & & & & \\
\hline & & & & $\underline{\text { Residential }}$ & Other & $\underline{\text { Residential }}$ & Other \\
\hline Oahu, $1988^{1}$ & 6,096 & 1,571 & 4,525 & 7,325 & 148,179 & 0.0797 & 0.0641 \\
\hline Oahu, $1997^{2}$ & 7,040 & 1,852 & 5,188 & 7,755 & 157,330 & 0.1336 & 0.1025 \\
\hline \multicolumn{3}{|c|}{ 1. State of Hawaii (1989). } & & & & & \\
\hline \multicolumn{3}{|c|}{ 2. State of Hawaii (1998b). } & & & & & \\
\hline
\end{tabular}

WSCo owned a power plant to generate electricity using bagasse as fuel. Its capacity was about 8 MW and it generated about 60 million kWh per year. This power was used in the sugar processing plant, for irrigation water pumping, and for export to the utility company. After sugarcane production ceased in 1996, power generation continued for more than two years using other biomass sources and petroleum fuels. The company currently focuses on diversified agriculture and the power plant facility has been sold to a company outside of the State (Tanabe, 1999). 


\subsection{Candidate Ethanol Crops and Their Output Potential at WSCo Site}

The plant species selected for ethanol production depends on its suitability to WSCo. Sugarcane grown commercially in WSCo should be one of the best crops for producing ethanol, and has advantages over most other ethanol crop candidates, including a well developed infrastructure, and cultivation and harvesting practices. Owing to the high yield potential of sugarcane, and the existing infrastructure and inherent advantages for producing fuel ethanol, sugarcane is the primary ethanol crop candidate in this investigation.

Banagrass, which has similar cultivation practices as sugarcane, is another strong ethanol crop candidate for the WSCo site. The well developed infrastructure and cultivation and harvesting techniques can be applied to banagrass cultivation. Although the ethanol yield from banagrass $(\sim 1870$ gal per acreyear, see Section 3.4.) is not as high as sugarcane ( 2280 gal per acre-year), its production cost (\$66 per ton, see Section 6.3.) is lower than for sugarcane ( $\$ 85$ per ton). The ethanol crops and their yield potential at WSCo are summarized in Table 7-7.

Table 7-7. Ethanol crops and their yield potential at WSCo site.

\begin{tabular}{|c|c|c|c|}
\hline \multirow[t]{3}{*}{$\underline{\text { Site }}$} & $\underline{\text { Land size }}$ & \multicolumn{2}{|c|}{$\underline{\text { Biomass yield }}$} \\
\hline & (acres) & \multicolumn{2}{|c|}{ (ton/day) } \\
\hline & & Sugarcane & Banagrass \\
\hline Former Waialua Sugar Company & $\sim 12,000$ & 720 & 880 \\
\hline 1. Yield is based on irrigated con & & & \\
\hline
\end{tabular}

\subsection{Potential Bioresidue Supplies for Ethanol Production}

The crops described above can yield substantial quantities of feedstock for ethanol production at WSCo. Residues produced by other agricultural activities in Hawaii and municipal solid wastes (MSW) also contain significant amounts of lignocellulosic material. Diversion of these materials from landfills can make feedstocks available at a reasonable cost for conversion to ethanol. These agricultural residues and MSW can supplement or replace dedicated ethanol crops as feedstock for ethanol conversion.

Various agricultural crops are produced in the State, including sugarcane, pineapple, macadamia nuts, fruits, vegetables, and melons. Among them, only sugarcane, pineapple, macadamia nuts, and coffee are produced in large volumes. Farming of these crops in large tracts of land makes collection of their residues more feasible. Residues from sugarcane, pineapple and macadamia nuts were considered in this investigation. Sugarcane generates large amounts of residue. Sugarcane residue has been viewed as an important energy source in previous studies, such as in the Hawaii Biomass Database (Hawaii Natural Energy Institute, 1994). With the end of sugarcane production on Oahu, sugarcane residues no longer are available on the island. Even though a sizable amount of pineapple is grown on Oahu (152,000 tons pineapple was produced on Oahu in 1996 (Hawaii Agricultural Statistics Service, 1997)) and production is anticipated to continue for some time, pineapple residues were not considered as a potential feedstock for ethanol production at the WSCo site because the amount of pineapple residues consolidated at any location on the island is quite modest (most of the pineapple grown on Oahu is exported to the mainland as fresh fruit and is not processed centrally).

MSW on Oahu contains about 32\% green material. Most MSW on Oahu is sent to the Honolulu Resource Recovery Venture ("H-Power") municipal solid waste conversion plant. In 1991, more than 600,000 tons of MSW (roughly one-half of the 1,200,000 tons produced in the State) was processed by H- 
Power (Kinoshita and Staackmann, 1994). Another important source of MSW is paper waste, which is estimated to be produced at almost 2 pounds per capita per day (Shleser, 1994). Currently, much of this material does not enter the disposal system and is potentially available. At present, much of the newspaper collected in Hawaii is sold to Asian markets for about $\$ 8.00$ per ton (Shleser, 1994). Paper waste is included, but other MSW components are neglected, in this investigation.

Table 7-8 presents the sources and quantities of agricultural residues and MSW which can supplement dedicated crops for ethanol conversion. The data suggest that, in total, more than 1,000 tons per day of residues and waste material can be supplied to ethanol conversion facilities on Oahu. While this is a substantial amount of resource for ethanol production, difficulties in large scale collection of MSW and the variability of agricultural product output give rise to uncertainty in supplies.

Table 7-8. Potential quantities of residues for ethanol at WSCo site.

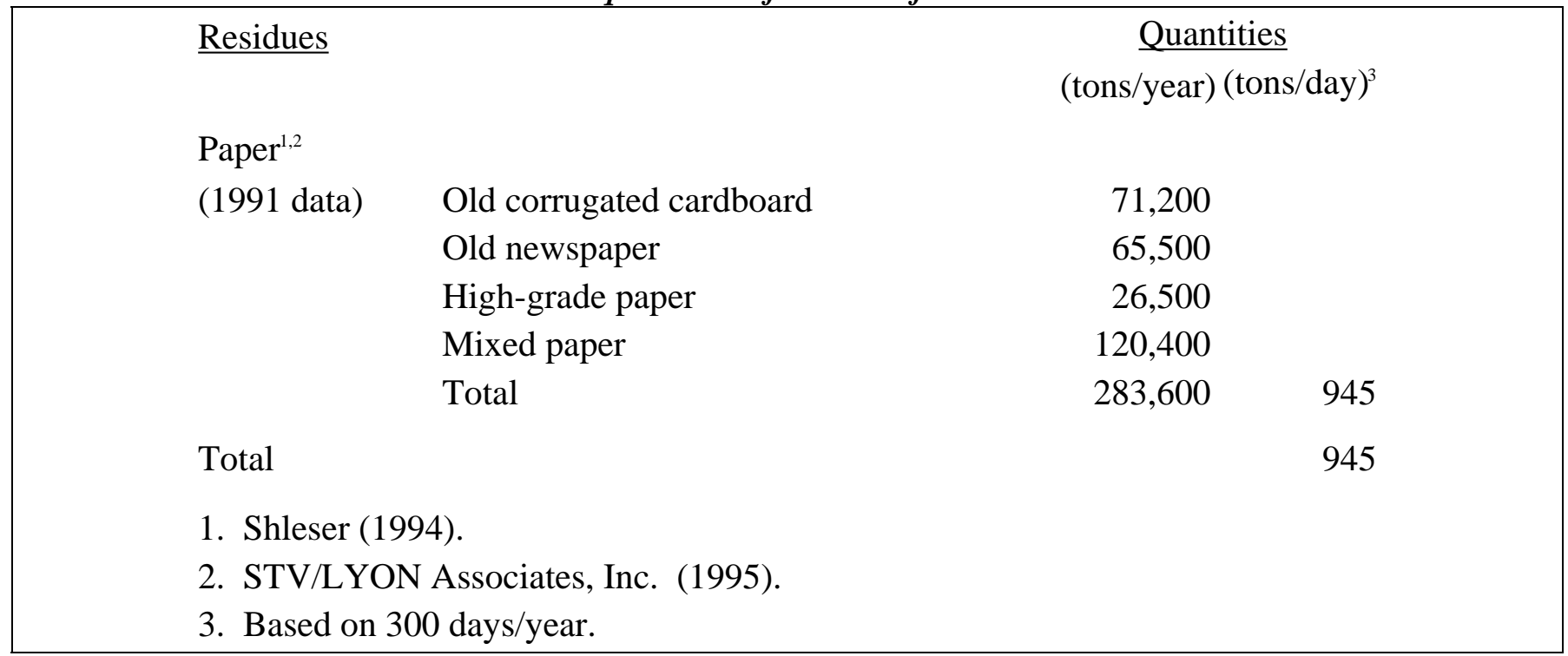




\section{Case Study 2 - Hawaiian Commercial \& Sugar Company Site}

\subsection{General Description}

Hawaiian Commercial \& Sugar Co. (HC\&S), located in central Maui and on the western slopes of Haleakala (Fig. 8-1), is Hawaii's largest sugar plantation. The plantation is bordered on two sides by the west and east Maui mountains, and the Pacific Ocean on the north and south. Samuel Alexander and Henry Baldwin, the founders of Alexander \& Baldwin, Inc. (A\&B), the parent company of HC\&S, had their beginnings in 1869 with about 12 acres of ranch land. After numerous acquisitions, name changes, and mergers, the operations evolved into HC\&S. In 1898, A\&B acquired the original HC\&S. This operation, formerly named Hawaiian Commercial Company, with a mill in Sprecklesville, was founded in 1872 by Claus Spreckles (Decision Analysts Hawaii, Inc., 1989). HC\&S now operates two sugar factories, a larger one at Puunene which mills sugarcane grown in central Maui, and a smaller one at Paia which mills cane grown to the east and at higher elevations.

HC\&S owns about 52,300 acres of land. Of this acreage, HC\&S farms about 36,400 acres, and produces about 200,000 tons of raw sugar from 17,000 acres harvested annually. HC\&S also generates electricity from bagasse and the electricity is used internally at HC\&S or sold to Maui Electric Company, Inc. (MECO) for resale to the public. Export by HC\&S totaled 108 million kWh in 1986, which accounted for $16.4 \%$ of the energy sold by the utility.

Fig 8-1a Location of HC\&S plantation site on Maui island.

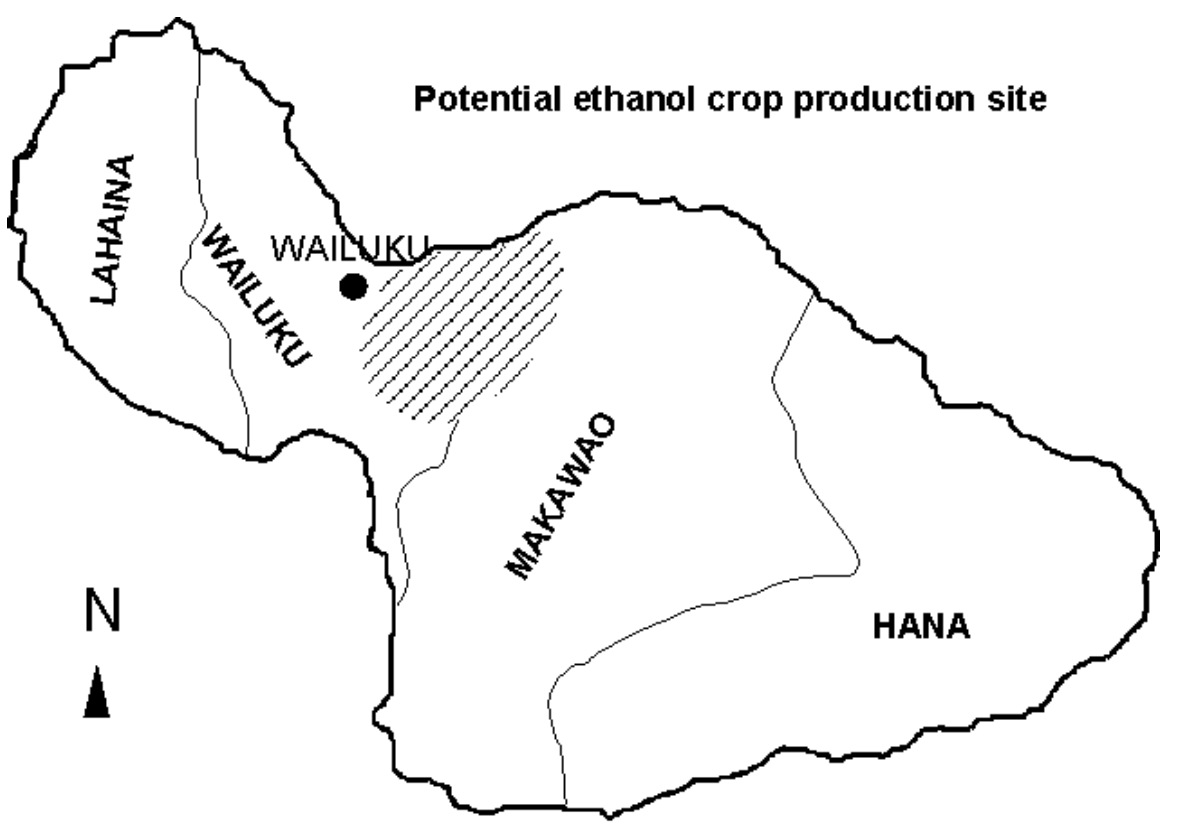

MAUI

Historically, HC\&S has been an efficient, large producer, and has been the most profitable plantation in the State in part, because of economies of scale. Its profitability reflects high yields over a large volume, combined with sufficient investment to maintain efficient operations. Although most of the sugar companies in Hawaii have closed during the last ten years, HC\&S is still in operation with profitable sugar production.

Sugarcane is grown on more than 157 fields at HC\&S, averaging 230 acres per field. In 1996, average yield of sugar per acre was about 11.7 tons (Hawaiian Sugar Planters' Association, 1996b). The entire plantation is irrigated, using drip or furrow irrigation systems. The large volume of irrigation water 
used at HC\&S is delivered by East Maui Irrigation Co. (EMI), a subsidiary of A\&B established in 1908. Water requirements and application vary, depending on rainfall. Water application averaged $355 \mathrm{mgd}$ in 1986 and $305 \mathrm{mgd}$ in 1987. Most of the water comes from surface sources, delivered by a 75-mile network of ditches, which has a collective capacity of $450 \mathrm{mgd}$.

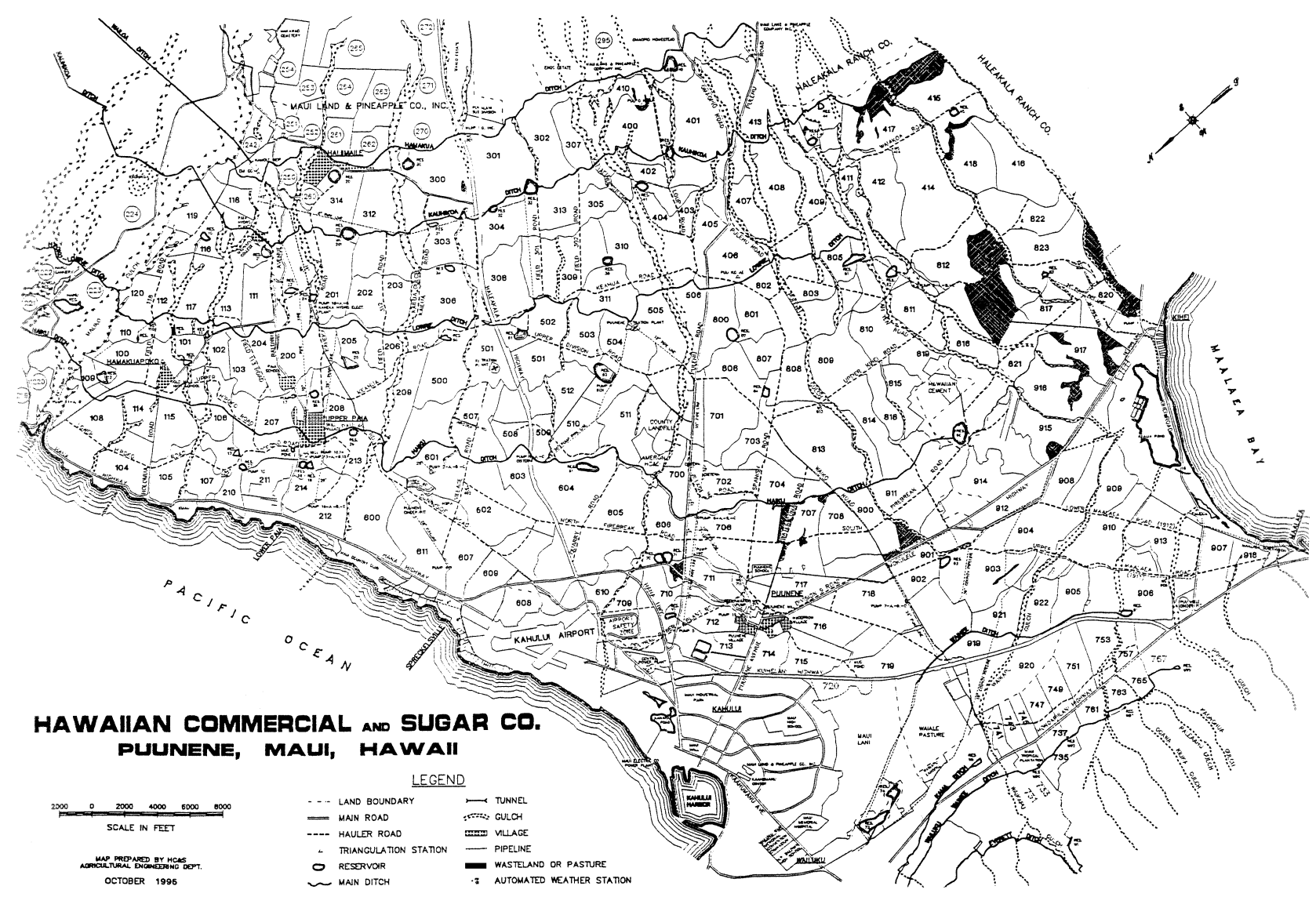

Fig. 8-1b. HC\&S sugarcane field designations

\subsection{Agronomic Conditions}

\subsubsection{Climate}

The equable temperature on Maui reflects the small seasonal variation in solar energy and the tempering effect of the surrounding ocean. The average temperature ranges from $74-75^{\circ} \mathrm{F}$ in March to 79 $80^{\circ} \mathrm{F}$ in September. The warmest and coolest months differ, on average, by less than $9^{\circ} \mathrm{F}$, and the daily temperature variation range exceeds the seasonal range. Temperature at sea level averages $75^{\circ} \mathrm{F}$, and decreases about $1^{\circ} \mathrm{F}$ for every 200 to 300 foot increase in elevation. Because most lands in HC\&S lie below 1200 feet, there is only slight temperature variation over the plantation.

The median annual rainfall for agricultural lands farmed by HC\&S ranges from 10 to 50 inches (University of Hawaii, 1967b). Most of the lands have median annual rainfalls between 15 and 35 inches. Lands in the north and in the northwest receive slightly higher rainfall, in the range of 25 to 40 inches annually. Lands located in the south receive less rainfall, ranging from 10 to 20 inches. Because highyielding grass crops require 100 inches or more water per annum, essentially all of the lands presently farmed by HC\&S would need to be irrigated to obtain high commercial yields of ethanol crops.

Agricultural lands farmed by HC\&S receive relatively high insolation, 450 to 560 langleys, with inland areas having lower insolation than coastal areas. 


\subsubsection{Topography}

As stated earlier, lands having slopes below $10 \%$ are best suited for cultivating and harvesting energy crops. Most of the lands farmed by HC\&S have slopes below 10\% (University of Hawaii, 1967b). Field equipment for ethanol-crop production, which are similar to those presently used at HC\&S, should not have much difficulty negotiating the terrain upon which sugarcane is presently grown at HC\&S.

Lands cultivated by HC\&S fall into two major elevation classes. Lands located in the north are relatively low lying ( $<300$ feet in elevation), while lands farther from the coastline, located in the south or southeast, are at higher elevation, 300 to 1200 feet.

\subsubsection{Soil}

Lands farmed by HC\&S have the following soil classifications: Aridisols, Entisols, Inceptisols, Mollisols, Oxisols and Ultisols. Most areas are covered with Mollisols, Oxisols, and Entisols (Kilham, 1996; University of Hawaii, 1983). The soil order distribution at HC\&S is shown in Fig. 8-2.

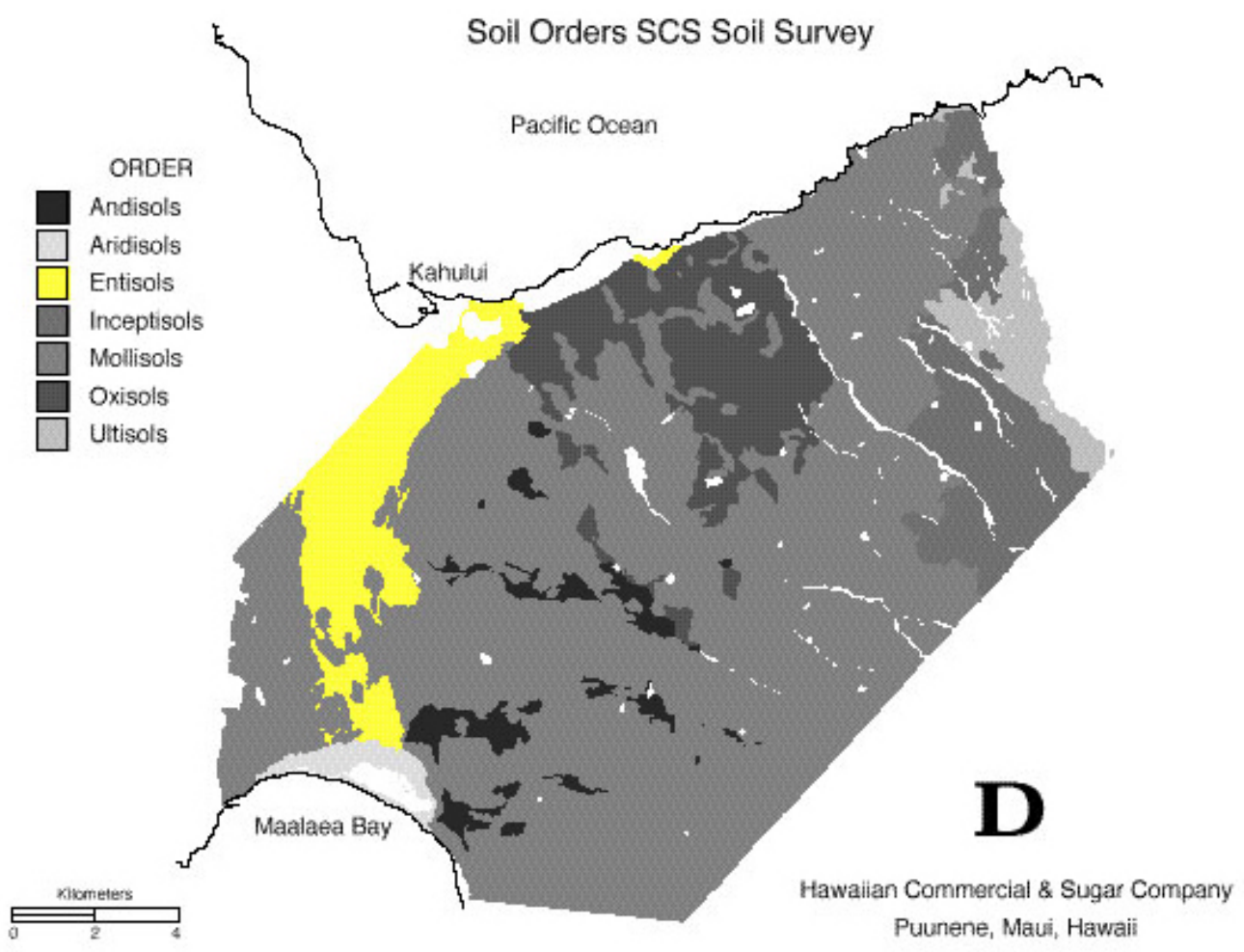

Fig. 8-2. Distribution of soil type, by soil order, at HC\&S.

The best soils for biomass production are Mollisols and Oxisols. The majority of the lands extending inland from the northern coast to the southern coast of HC\&S are classified as Mollisols. Mollisols are well-drained, relatively young soils that develop on coral, lava, or alluvium. They are dark or red-colored, base-rich mineral soils, relatively high in organic matter, generally rich in plant nutrients. Mollisols have good natural fertility (although this varies with weather conditions), do not harden as they dry, and are excellent for agriculture. 
Oxisols are located only on old geomorphic surfaces, mostly on relatively flat, low-lying land in the northern, coastal region. Oxisols are the most weathered soil with very high (up to 90\%) clay content. When properly managed, Oxisols are highly productive. Oxisols have high permeability, causing leaching of soluble plant nutrients, and have moderate water retention. These soils show exceptional resistance to physical deterioration under intensive mechanized agriculture and are an important agricultural soil in the Hawaiian islands. Entisols, formed from any type of parent materials, are used in agriculture; however, their suitability depends on location, water supply, and texture.

A soil survey identified 12 different soil series on lands farmed by HC\&S (Fig. 8-3). Jaucas and Puuone sands come across the saddle of Maui. Pulehu soil series lies adjacent to the ocean. Paia, Haliimaile, and Hamakuapoko soil series are located in the northeastern (windward) section of HC\&S. The most common soil series at HC\&S are of the Paia, Keahua, Waiakoa, and Molokai type.

Most of the plantation's soils belong to the soil order Mollisols, spanning soil series Ewa, Keahua, Paia, Pulehu, and Waiakoa (Kilham, 1996). Soil texture is an important property that determines how much water can be stored in the soil. Fig. 8-4 summarizes the soil texture of HC\&S plantation lands. Most of $\mathrm{HC} \& \mathrm{~S}$ is classified as silty clay loam. Silty clay is located in higher rainfall areas while the sands are windblown across the saddle of Maui from Kahului to Maalaea Bay. Soil moisture storage represents the amount of water stored in the soil at an average rooting depth for furrow irrigation. Most lands at HC\&S have soil moisture storage values exceeding $85 \mathrm{~mm}$ (Kilham, 1996).

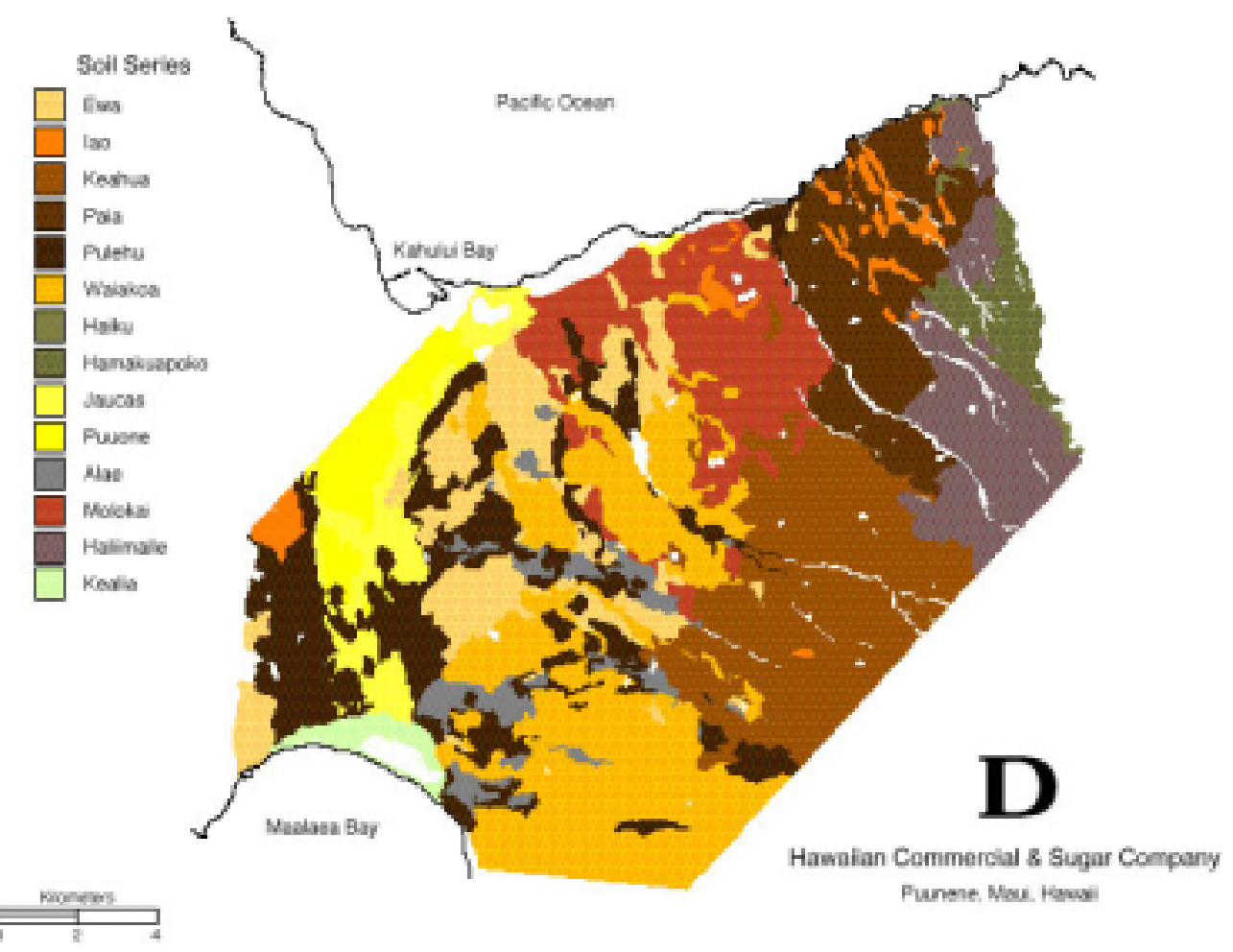

Fig. 8-3. Distribution of soil type, by soil series, at $H C \& S$. 


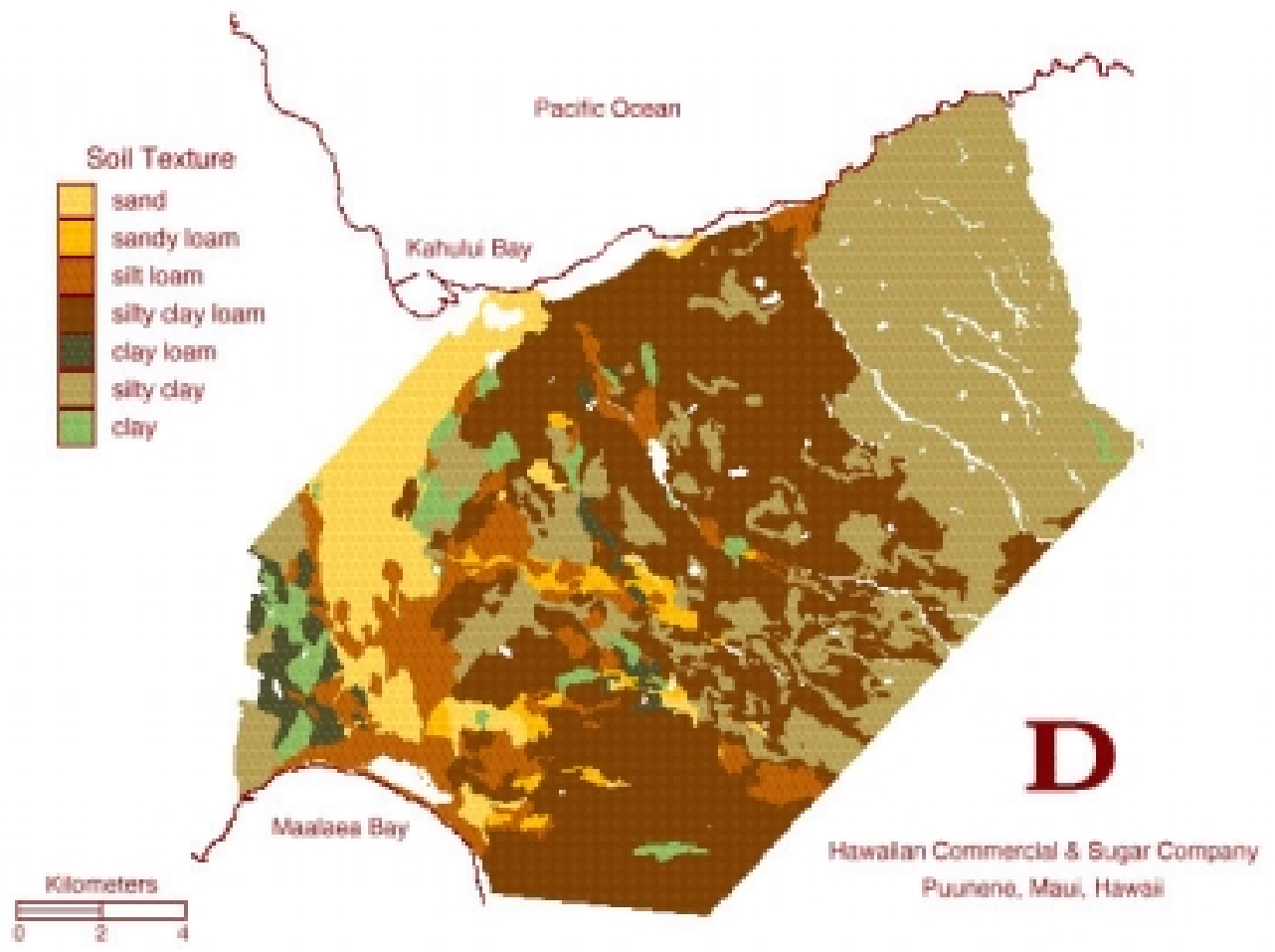

Fig. 8-4. Distribution of soil type, by soil texture, at HC\&S.

\subsection{Water Supply at HC\&S}

Maui island receives an average of 80 inches of rain annually. Most of the rain falls on the eastern mountain areas; only $30 \%$ of the rain falls on the central and western areas where most of economic activity prevails. Surface water, most of which comes directly from rainfall, has to be conveyed from the mountains to the central and western areas. Groundwater has been used for more than a century on Maui. Most of the operating wells belong to major sugar and pineapple companies. These wells, having a total yield of 215 $\mathrm{mgd}$, are used mainly for agriculture. About $21 \mathrm{mgd}$ of groundwater is used for domestic, industrial, and commercial purposes on the island. Water sources and consumption on Maui island are summarized in Table 8-1.

The dominant water resources on Maui are groundwater and surface water. Maui has the potential to deliver, on a sustainable basis, as much as 475 million gallons of potable groundwater per day. Only about $120 \mathrm{mgd}$ of groundwater is consumed, mostly by agriculture (Table 8-1). Domestic use of groundwater on Maui increased from $14 \mathrm{mgd}$ in 1985 to $20 \mathrm{mgd}$ in 1995. As more residential communities are developed over the next ten years, Maui County plans to increase groundwater withdrawal to about $36 \mathrm{mgd}$ by 2010 (County of Maui, 1990). Because domestic consumption of groundwater is only a small percentage of the total groundwater available on the island, more than $440 \mathrm{mgd}$ of the groundwater resources can be used for other economic activities, particularly for agriculture.

Surface water is supplied directly from rivers, streams, and ditches. Catchment systems (dams and reservoirs) have been built in many areas to ensure reliable supplies of water. EMI built a surface water collection system capable of transporting an average of $164 \mathrm{mgd}$ of surface water to sugarcane fields (County of Maui, 1990). The Federal Safe Drinking Water Act of 1986 requires treatment of all surface waters. This substantially increases the cost of operating a surface water system. As a result, groundwater, rather than surface water, often is the preferred water source of private and public water supplies. Surface water, being in lower demand, is a more readily available source of water for agriculture. 
Table 8-1. Water sources and consumption on Maui island.

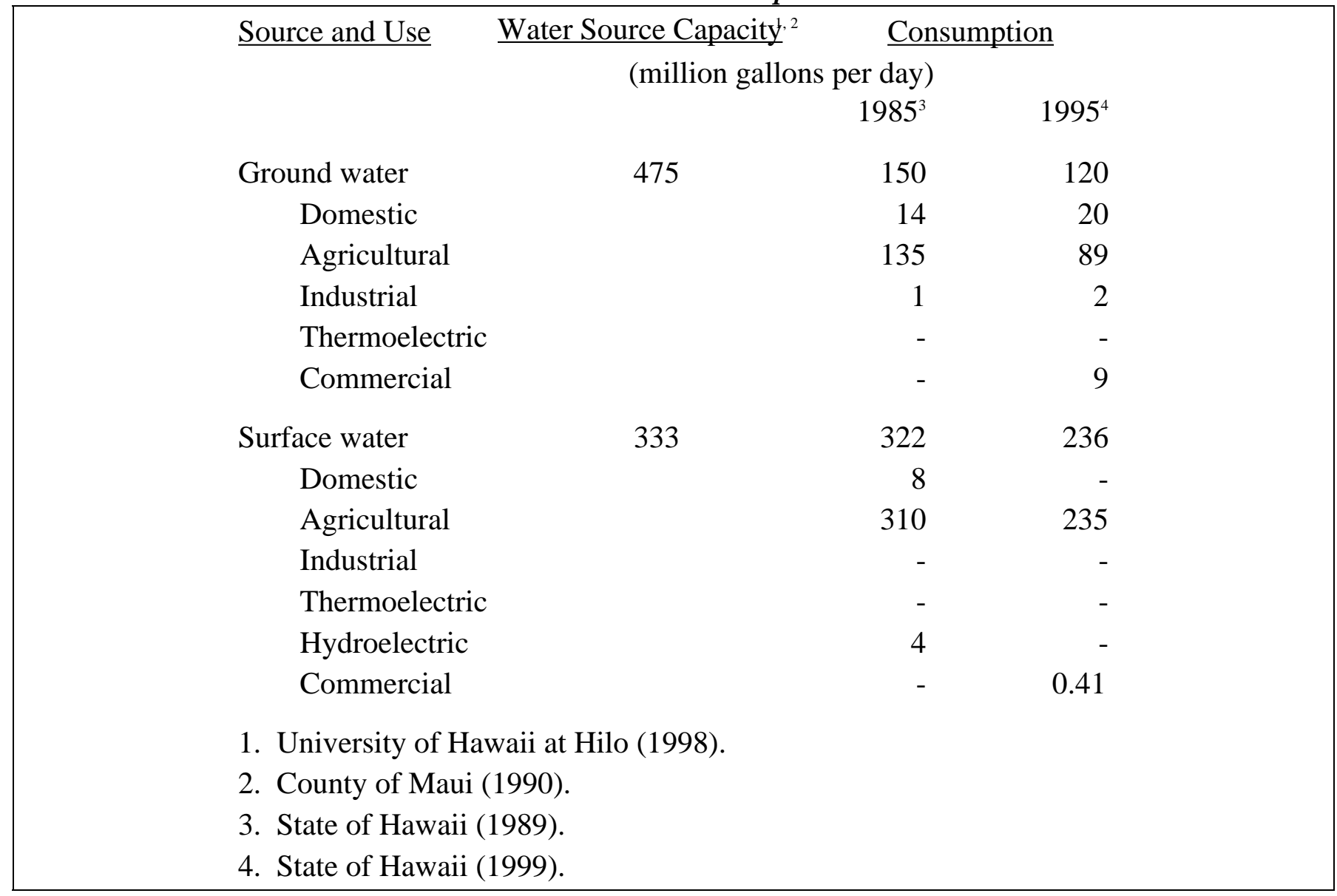

Drip irrigation is used widely at HC\&S. Irrigation water comes from three sources, surface water, groundwater, and cane-cleaner effluent from the sugar mill. The water supply capacity and water consumption for sugarcane production at HC\&S are presented in Table 8-2.

Table 8-2. Water supply capacity and water consumption at HC\&S.

\begin{tabular}{|lcc|}
\hline $\begin{array}{l}\text { Source and Use } \\
\text { Surface Water }\end{array}$ & $\begin{array}{c}\text { Deliver Capacity } \\
\text { (million gallons per day) }\end{array}$ & 189 \\
Lowrie Ditch & 60 & \\
New Haiku Ditch & 100 & \\
Wailoa Ditch & 195 & 167 \\
Kauhikoa Ditch & 110 & 244 \\
Ground Water & & \\
1. Wilcox (1996). & & \\
2. County of Maui (1990). & & \\
\hline
\end{tabular}


The water collection and distribution system on Maui is shown in Fig. 8-5. There are four major ditches in the HC\&S area, Lowrie Ditch, Kauhikoa Ditch, New Haiku Ditch, and Wailoa Ditch.

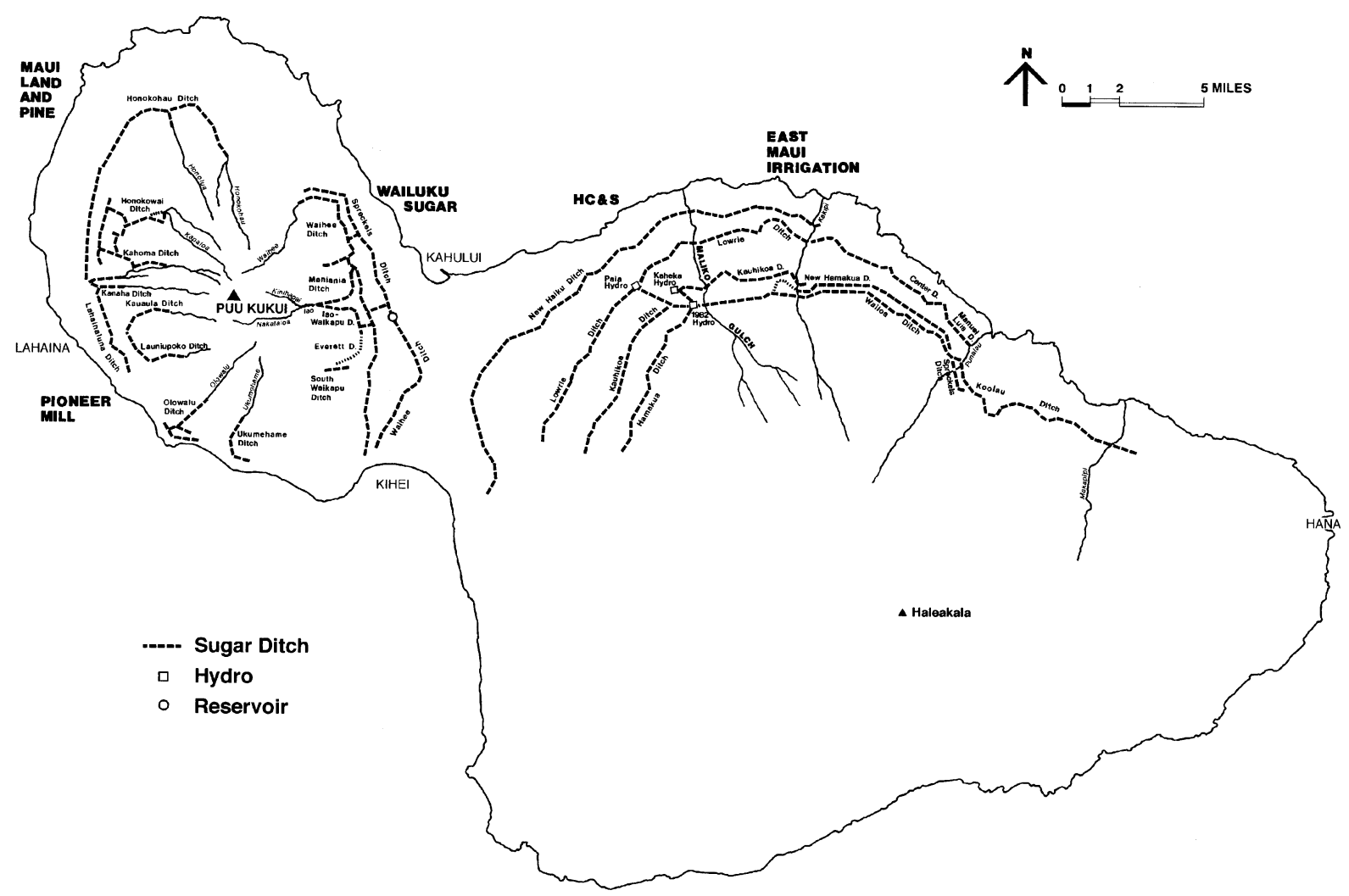

Fig. 8-5. Water collection and distribution systems at HC\&S.

Part of the irrigation water at HC\&S is supplied through these ditches via EMI (Wilcox, 1996). The Lowrie Ditch was constructed in 1899-1900, and has a capacity of $60 \mathrm{mgd}$, capable of irrigating about 6000 acres. This ditch originates in the Kailua rain forest in the Makawao district and has two sources. The first is a reservoir at Papaaea that is fed by two five- to six-mile ditches. The second source is Kailua stream. The New Haiku Ditch was completed in 1914 and has a capacity of $100 \mathrm{mgd}$. It is mostly a tunnel system, partially lined, having a length of 10 miles. Kauhikoa Ditch was completed in 1915, is nearly 6 miles long and has a capacity of $110 \mathrm{mgd}$. Wailoa Ditch was started in 1918 and completed in 1923. Mostly lined tunnel, with a length of nearly 10 miles, it had an original capacity of $160 \mathrm{mgd}$ which later was increased to $195 \mathrm{mgd}$.

The water source for these ditches is primarily surface runoff from a total watershed area of 56,000 acres. Of this watershed, EMI owns 18,000 acres; the remaining 38,000 acres belongs to the State of Hawaii. The State issues a license to EMI for water originating on government land. EMI controls only surface water sent to HC\&S and cannot always meet plantation requirements, $200 \mathrm{mgd}$. Groundwater is a major source of supplemental irrigation water. HC\&S has deep pumping stations with the ability to pump more than $167 \mathrm{mgd}$ of groundwater (County of Maui, 1990). Groundwater levels range from several inches to about 6 feet in the upper areas of HC\&S. Water level increases inland and towards the East Maui mountains at a rate of about 1 foot per mile.

\subsection{Transportation at HC\&S}

The road network on Maui consists of four highways and many other roads. The State built and maintains Honoapiilani Highway, Hana Highway, Kula Highway and Piilani Highway, which provide the 
major routes for intra-island transportation. The State also maintains several other secondary highways. The County of Maui maintains a substantial network of roads throughout the island. Most of the County roadways service rural homestead communities that are scattered throughout the island. HC\&S, located in central Maui, has good transportation infrastructure, with three highways and other city roads passing through the region (Fig. 8-6; Table 8-3). The distances from HC\&S to the airport and the harbor are short, less than 3 miles.

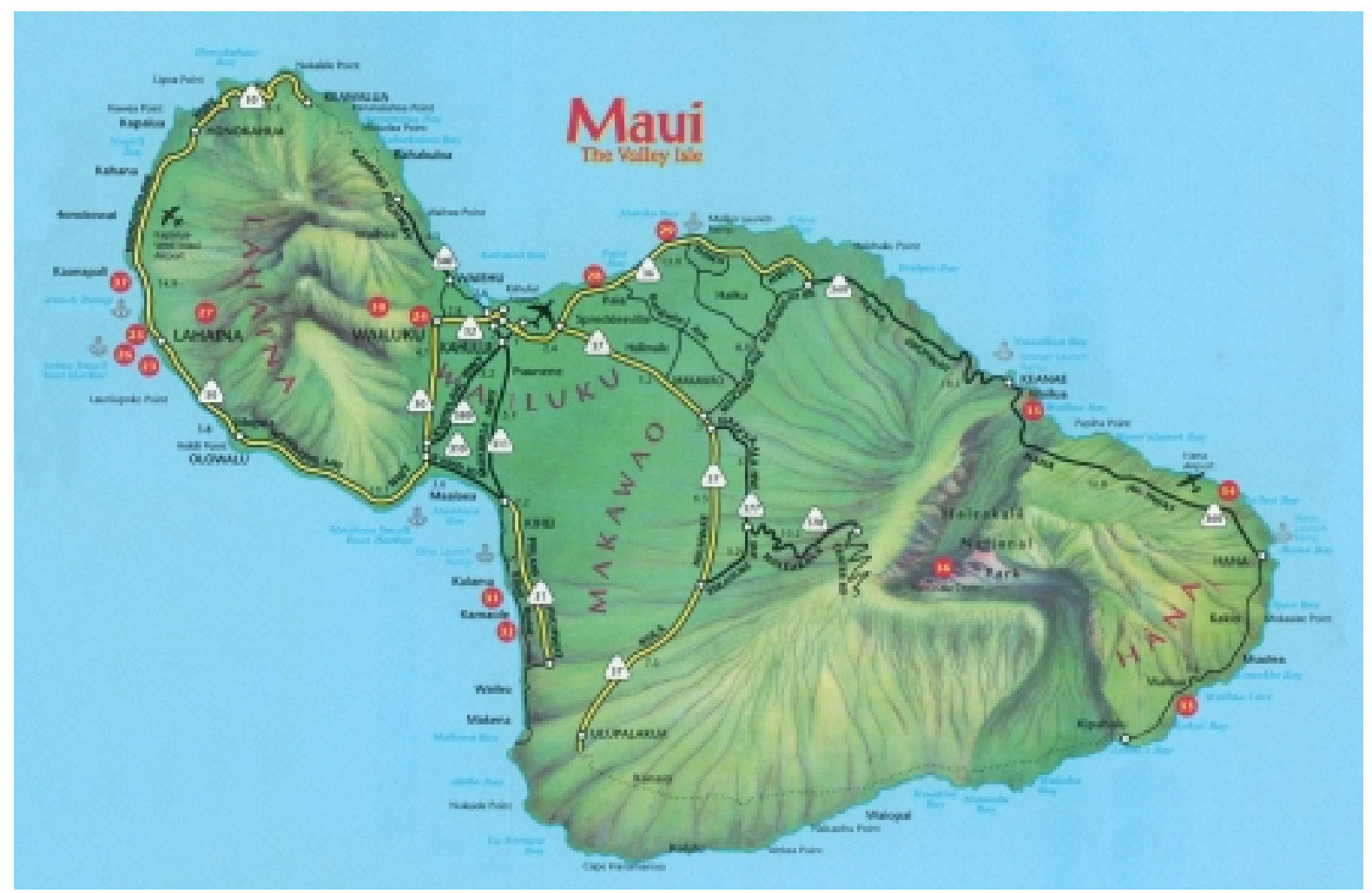

Fig. 8-6. Transportation map of Maui Island.

Table 8-3. Ground Transportation in HC\&S area.

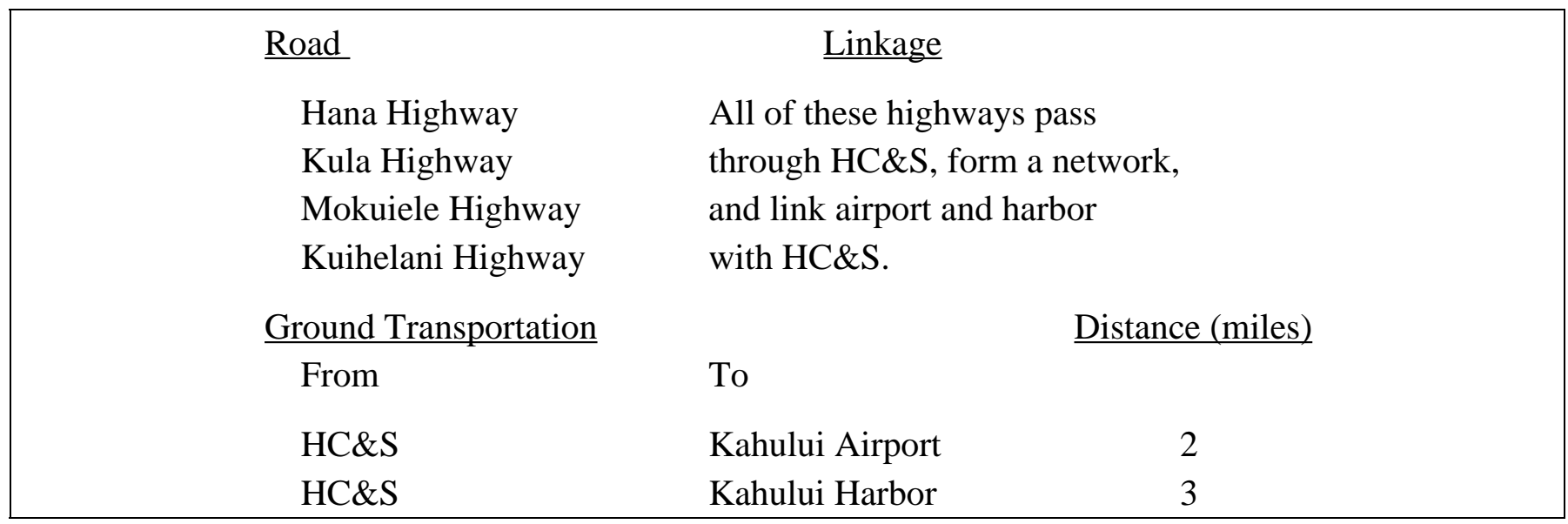

HC\&S owns and maintains a network of private agricultural roads, including a broad, paved canehauling system that runs from the fields to the sugar mill. This road network, shown in Fig. 8-1, provides for efficient ground transportation in sugarcane production. Because ethanol-crop production (grass species) 
would be similar to sugarcane production, the existing road network would be well suited for ethanol-crop production.

Maui has one deep-draft harbor, Kahului Harbor, which has a basin depth of 35 feet. This port serves the island for exporting of sugar, cattle, and other commodities and for importing capital and consumer goods. Most fuel, equipment, chemicals, supplies, and construction material have to be imported to the island. Harbor entrance depth and other information for this commercial harbor are presented in Table 8-4. A major disadvantage with marine transportation in Hawaii is its high cost due to conditions imposed by the Jones Act (refer to discussion on Transportation at the Waialua site).

Table 8-4. Commercial harbor on Maui ${ }^{1}$.

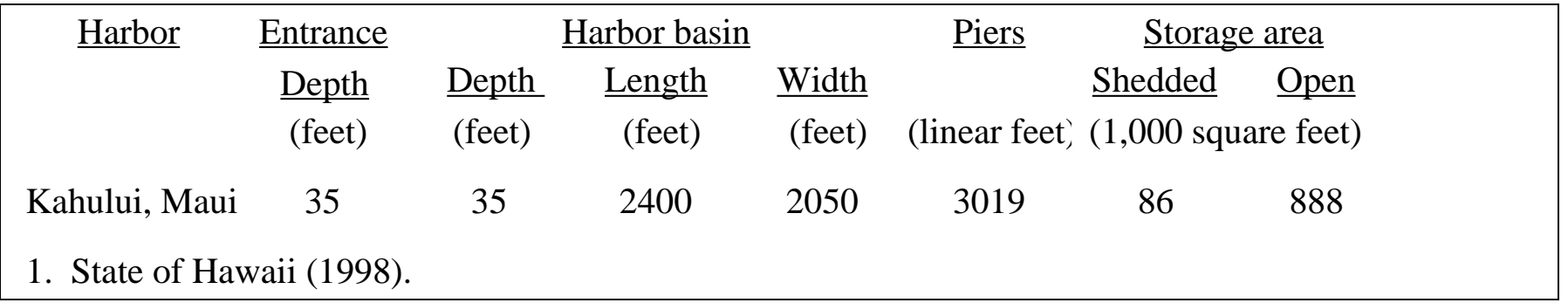

\subsection{Electricity Supply at HC\&S}

MECO, a subsidiary of HECO, provides utility electricity service on Maui and the other two islands of Maui County. In 1994, MECO sold 960 GWh to its customers. MECO's own generators produced 933 $\mathrm{GWh}$, or $90.4 \%$, of all power generated and imported by MECO (1031 GWh). The remainder was generated by sugar plantations and exported to MECO for resale. The generators at MECO and the sugar plantations consumed about $140 \mathrm{GWh}$.

The electricity generation capacity on Maui is presented in Table 8-5. The total firm generation capacity on Maui is $213 \mathrm{MW}$, of which MECO owns $197 \mathrm{MW}$, or 92\%. The power purchase agreement between MECO and HC\&S provides an additional $16 \mathrm{MW}$ of firm capacity. A system peak of $175 \mathrm{MW}$ was reached in 1997 (State of Hawaii, 1998b). The firm power generation capacity comfortably exceeds power consumption on the island.

In 1997, the average price for electricity on Maui was $\$ 0.16$ per $\mathrm{kWh}$ for residential customers and $\$ 0.14$ per kWh for other users, about 56\% higher than in 1988. Table 8-6 summarizes electricity consumption and prices on Maui island. The price for electricity on Maui is higher than on Oahu, owing largely to the added cost of inter-island transport of oil and to diseconomies relating to power plant scale.

The sugar industry has played an important role in Maui's electricity generation mix. As shown in Table 8-5, HC\&S provides firm baseload electricity generation capacity of $16 \mathrm{MW}$ and non-firm capacity of $42 \mathrm{MW}$. HC\&S owns two sugar mills, at Paia and Puunene, each having power plants. The Paia power plant has a capacity of $10 \mathrm{MW}$ and generated $40 \mathrm{GWh}$ in 1994, which was only sufficient to cover electricity consumption by the sugar mill and sugarcane production in the Paia area. The Puunene power plant, with 42 MW of capacity, generated $185 \mathrm{MWh}$ in 1994. The Puunene plant exported about $102 \mathrm{GWh}$ to the utility company and consumed about $84 \mathrm{GWh}$ in the sugar mill and in the fields. The hydroelectric power plant owned by HC\&S generated about 23 MWh in 1993. 
Table 8-5. Electrical generation capacity on Maui island ${ }^{1}$.

\begin{tabular}{|c|c|c|c|}
\hline Owner & $\underline{\text { Fuel }}$ & Mode of Operation & $\frac{\text { Capacity }}{\text { (MW) }}$ \\
\hline MECO & $\mathrm{MSFO}^{2} /$ Diesel & Firm Baseload & 95.6 \\
\hline MECO & Diesel & Firm Baseload/Cycling & 50 \\
\hline $\mathrm{MECO}$ & Diesel & Firm Cycling & 38.6 \\
\hline MECO & Diesel & Firm Peaking & 12.5 \\
\hline $\mathrm{HC} \& \mathrm{~S}$ & Bagasse/Coal/Oil & Firm Baseload & 16 \\
\hline & & Firm Capacity Subtotal & 212.7 \\
\hline Sugar Plantation & Hydro & Non-Firm ${ }^{3}$ & 6.2 \\
\hline HC\&S Paia & Bagasse/Oil & Non-Firm & 10 \\
\hline HC\&S Puunene & Bagasse/Coal/Oil & Non-Firm & 26 \\
\hline Pioneer Mill & Bagasse/Oil & Non-Firm & 9.3 \\
\hline & & n-Firm Capacity Subtotal & 51.5 \\
\hline & & Iaui Island Capacity Total & 264 \\
\hline \multicolumn{4}{|c|}{$\begin{array}{l}\text { 1. State of Hawaii (1995a). } \\
\text { 2. Medium-Sulfur Fuel Oil. } \\
\text { 3. Non-Firm refers the power provided on an as available/as needed basis. }\end{array}$} \\
\hline
\end{tabular}

Table 8-6. Electricity consumption and price on Maui island.

\begin{tabular}{|c|c|c|c|c|c|c|c|}
\hline \multirow[t]{3}{*}{ Island } & \multicolumn{3}{|c|}{ Power Consumption } & \multirow{2}{*}{\multicolumn{2}{|c|}{$\frac{\text { Average Annual Use }}{(\mathrm{kWh} / \mathrm{user})}$}} & \multirow{2}{*}{\multicolumn{2}{|c|}{$\frac{\text { Average Rate }}{(\$ / \mathrm{kWh})}$}} \\
\hline & \multirow[b]{2}{*}{ Total } & \multirow{2}{*}{$\begin{array}{c}(\mathrm{GW}) \\
\underline{\text { Residential }}\end{array}$} & \multirow[b]{2}{*}{$\underline{\text { Other }}$} & & & & \\
\hline & & & & $\underline{\text { Residential }}$ & Others & $\underline{\text { Residential }}$ & $\underline{\text { Others }}$ \\
\hline Maui, 1988 & 668 & 217 & 451 & 6,653 & 75,174 & 0.0997 & 0.0915 \\
\hline Maui, $1997^{2}$ & 969 & 329 & 640 & 7,613 & 88,650 & 0.1555 & 0.1389 \\
\hline \multicolumn{3}{|c|}{ 1. State of Hawaii (1989). } & & & & & \\
\hline \multicolumn{3}{|c|}{ 2. State of Hawaii (1998b). } & & & & & \\
\hline
\end{tabular}

Table 8-7 summarizes the electricity generation capacity, output, and consumption at HC\&S.

Table 8-7. Electricity generation capacity, output, and consumption at HC\&S .

\begin{tabular}{|c|c|c|c|c|c|}
\hline Location & $\underline{\text { Fuel }}$ & $\frac{\text { Capacity }}{\text { (MW) }}$ & $\frac{\text { Generated }}{(\mathrm{GWh})}$ & $\frac{\text { Consumption }}{(\mathrm{GWh})}$ & $\underline{\text { Year }}$ \\
\hline HC\&S, Paia plant & Bagasse/Oil & 10 & 40 & 40 & 1994 \\
\hline HC\&S, Puunene plant & Bagasse/Coal/Oil & 42 & 185 & 84 & 1994 \\
\hline Kaheka, Paia, Hamakua & Hydro & 5.9 & 23 & & 1993 \\
\hline
\end{tabular}


Power generation at HC\&S, about 225 GWh total, accounted for more than $20 \%$ of the total electric energy consumed on the island in 1994. Because the steam generators at Puunene can burn bagasse, oil, or coal as fuels, the power generation capacity at HC\&S is not critically reliant on bagasse supplies.

\subsection{Candidate Ethanol Crops and Their Output Potential at HC\&S Site}

The selection of crop species for ethanol production at HC\&S should take into account the plantation's production history and current status. Commercial sugar production at HC\&S has a history of more than 130 year and remains profitable even though most of the other sugar mills in Hawaii have ceased operating due to lack of profitability. Sugarcane is an obvious candidate for producing ethanol at HC\&S, and has advantages over most other ethanol-crop candidates, including well developed infrastructure and cultivation and harvesting experience. Owing to its high yield potential, and existing infrastructure and inherent advantages in producing fuel ethanol, sugarcane is a primary ethanol crop candidate in this investigation, although producing ethanol would have to be more profitable than producing sugar in order for ethanol production to be adopted.

Banagrass is another obvious candidate for ethanol production at HC\&S. The well developed infrastructure and cultivation and harvesting experience in sugarcane production can be applied directly to banagrass production. Although the yield of ethanol from banagrass would not be as high as from sugarcane, banagrass production costs are anticipated to be lower than for sugarcane. The two selected ethanol crops and their yield potential at HC\&S are summarized in Table 8-8.

\subsection{Potential Bioresidues for Ethanol Production at HC\&S Site}

The crops described above can be produced in substantial quantities for ethanol production at HC\&S. Residues produced by other agricultural activities and MSW contain significant amounts of lignocellulosic materials that would be suitable raw materials for ethanol conversion. Diversion of these materials from landfills can make feedstock available for conversion to ethanol at a reasonable cost (sometimes subsidized by tipping fees). If these agricultural residues and MSW can be supplied at large enough quantities to satisfy much of the feedstock requirements for ethanol production, they can supplement or replace the dedicated ethanol crops as feedstock for ethanol conversion.

Table 8-8. Ethanol crops and their yield potentials at $\mathrm{HC} \& S$ site.

\begin{tabular}{|l|c|c|c|}
\hline \multicolumn{1}{|c|}{ Site } & $\underline{\text { Land size }}$ & \multicolumn{2}{c|}{$\begin{array}{c}\text { Biomass yield } \\
\text { (acres) }\end{array}$} \\
\hline & & Sugarcane & Banagrass \\
\hline Hawaiian Commercial \& Sugar Co. & $\sim 20,000$ & 1,200 & 1,467 \\
\hline 1. For irrigated crop, 300 days per year. & & & \\
\hline
\end{tabular}

Many different kinds of crops are produced on the Maui, including sugarcane, pineapple, macadamia nuts, fruits, vegetables, and melons. Among them, sugarcane is the most significant agricultural product. Cane and sugar production at HC\&S generates large amounts of residues. Bagasse is fully utilized at HC\&S, but often at less than optimal efficiency. Most of the cane trash is burned in the field. The total amount of both residues represents the largest source of raw materials available for ethanol production. Studies (e.g., Kinoshita, 1988) suggest that $\sim 35 \%$ of the fiber in standing sugarcane is consumed in openfield burning of cane. Sugarcane leaves and tops (often termed cane trash) can be a steady source of bioresidues if sugar production continues at HC\&S. 
The composition and quantity of MSW vary substantially depending on location. Maui County has a resident population of about 100,000 and the tourist industry brings large numbers of visitors to the island every year. MSW contains green materials from yards, hotels, golf courses, parks, and construction but poses difficulties in collection. Paper waste is an important component in MSW. Collection of paper waste is easier than other wastes because much of it presently does not enter the conventional disposal system. Paper waste is included and other types of MSW are neglected in this investigation.

Table 8-9 presents the sources and quantities of agricultural residues and MSW which can supplement dedicated crops for ethanol conversion. The data suggest that, in total, more than 1,800 tons per day of residues and waste material can be supplied to an ethanol conversion facility at $\mathrm{HC} \& \mathrm{~S}$. It is important to point out, however, that the amount of sugarcane residues shown in Table 8-9 is the total amount in the field crop, not all of which would be recoverable commercially. Moreover, most of the bagasse would not available for ethanol production because it is presently being used for sugarcane processing. Nevertheless, these residues and waste are logical candidates for ethanol production if their supplies can be sustained.

Table 8-9. Potential quantities of residues for ethanol at HC\&S site.

$\underline{\text { Residues }}$

\begin{tabular}{|c|c|c|c|}
\hline \multicolumn{2}{|l|}{$\underline{\text { Residues }}$} & \multicolumn{2}{|c|}{$\frac{\text { Quantities }}{\text { (tons/year) (tons/day) }}$} \\
\hline $\begin{array}{l}\text { Paper }^{1,2} \\
\text { (1991 data) }\end{array}$ & $\begin{array}{l}\text { Old corrugated cardboard } \\
\text { Old newspaper } \\
\text { High-grade paper } \\
\text { Mixed paper } \\
\text { Total }\end{array}$ & $\begin{array}{r}26,500 \\
9,500 \\
23,500 \\
10,400 \\
69,900\end{array}$ & 233 \\
\hline Agricultural & $\begin{array}{l}\text { ste } \\
\text { Sugarcane bagasse }(1997 \text { data })^{3,4} \\
\text { Sugarcane trash }(1997 \text { data })^{3,4} \\
\text { Pineapple silage }\end{array}$ & $\begin{array}{r}311,400 \\
168,000 \\
8,000\end{array}$ & $\begin{array}{r}1,038 \\
560 \\
27\end{array}$ \\
\hline $\begin{array}{l}\text { Total } \\
\text { 1. Shleser ( } \\
\text { 2. STV/LY } \\
\text { 3. Kinoshita } \\
\text { 4. Hawaii A } \\
\text { 5. Kinoshita } \\
\text { 6. Based on }\end{array}$ & $\begin{array}{l}\text { Associates, Inc. (1995). } \\
\text { d Staachmann (1994). } \\
\text { cultural Statistics Service (1997). } \\
\text { al. (1996). } \\
\text { days/year. }\end{array}$ & & 1,858 \\
\hline
\end{tabular}




\section{Case Study 3 - Former Hamakua Sugar Company Site}

\subsection{General Description}

Former Hamakua Sugar Co., Inc. (HSC), located along the north shore of the island of Hawaii (Fig. 9-1), began producing sugarcane in the 1880s as several separate companies under different ownership, and terminated its operation in 1994 as a single company. During its more than 110 years of operation, HSC grew to become the second largest sugar producer in the State, reaching peak production in the mid 1980s of approximately 145,000 tons of raw sugar and 42,000 tons of molasses per year. In addition, HSC sold $\sim 40$ million kWh of electricity annually to Hawaii Electric Light Co. (HELCO). HSC cultivated about 35,000 acres of sugarcane and harvested nearly 14,000 acres annually (Decision Analysts Hawaii, Inc., 1989; Hawaiian Sugar Planters' Association, 1989 - 1996a). The plantation area of HSC is about 35 miles long and $\sim 4$ miles wide.

Former sugarcane lands at HSC span elevations from near sea level to 2,700 feet, and receive varying amounts of rain, ranging from 50 inches to more than 160 inches per year (University of Hawaii at Hilo, 1998). Heavy rainfall in the area eliminated the need for costly irrigation systems and associated pumping costs in most sections of the plantation. Historically, HSC was a low-cost sugar producer, even though the average sugarcane yield was lower than some of the other producers due to lower insolation, frequent poor weather for operating farming equipment, and occasional lack of water.

\subsection{Agronomic Conditions}

\subsubsection{Climate}

An important feature of the island of Hawaii's climate is the wide variation in environments, from the very humid rain forests of Puna on the windward slopes to the hot, dry, desert-like climate on the leeward slopes. Temperature varies widely in part because of tall mountain masses. At sea level, the annual temperature averages $75^{\circ} \mathrm{F}$; by contrast, the summits of Mauna Kea and Mauna Loa, almost 14,000 feet above sea level, have near freezing temperature and are often snow capped during the winter months. Temperature decreases by $\sim 1^{\circ} \mathrm{F}$ for every 200 to 300 foot increase in elevation. The temperature in the HSC area ranges from $60^{\circ} \mathrm{F}$ to $85^{\circ} \mathrm{F}$ (University of Hawaii, 1983).

Fig. 9-1a. Location of

Hamakua site on the Island of Hawaii.

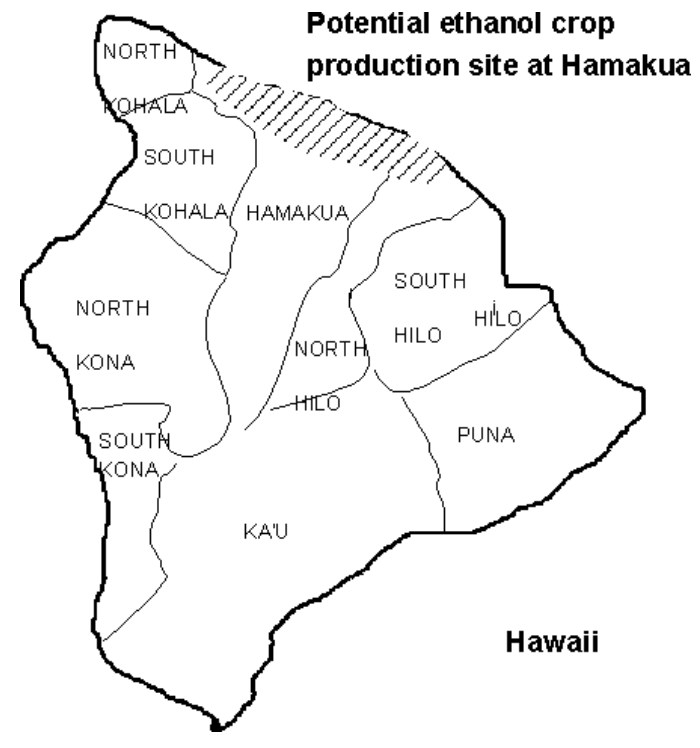




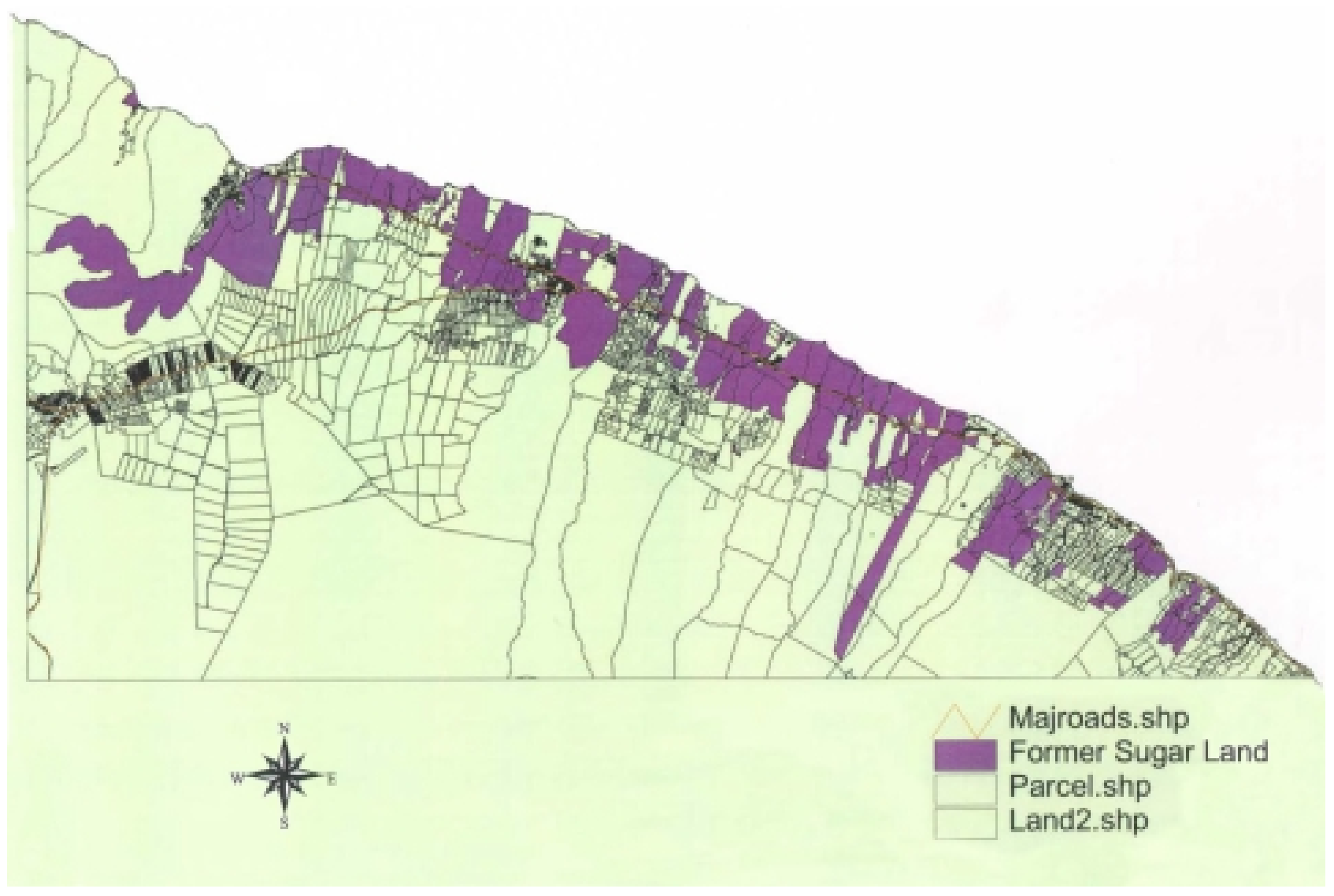

Fig. 9-1b. Field map of Hamakua site.

The median annual rainfall for agricultural lands farmed by HSC ranges between 75 and 150 inches, making this a high rainfall location. The maximum monthly rainfall can reach 90 inches and the minimum monthly rainfall is about 15 inches. The wettest season is winter, peaking around March; June has the lowest rainfall. High rainfall at most locations at HSC provides enough water for crops on an annualized basis; however, rainfall is insufficient in some locations and the rainfall pattern does not match the varying water requirements over the course of the crop. Due to abundant rainfall, soils are highly leached of plant nutrients; consequently, cultivated lands need to be fertilized intensively.

Agricultural lands farmed by HSC receive relatively low insolation rates of 350 to 425 langleys, with inland areas having lower insolation than coastal areas. The relatively low insolation at HSC is due to more frequent cloud cover than most other areas in Hawaii (University of Hawaii, 1983; Hawaii Natural Energy Institute, 1994), and limits the yield potential at that site.

\subsubsection{Topography}

Lands with slopes below $10 \%$ are best suited for field mechanization. Most of the lands farmed by HSC have slopes between 11 and 20\% (University of Hawaii, 1965). Lands cultivated by HSC vary in elevation from sea level to around 2,700 feet. Coastal lands are relatively low lying (sea level to 1,000 feet in elevation). Lands farther from the coastline generally are at higher elevation, ranging between 300 and 2,000 feet.

\subsubsection{Soil}

Soil on most lands farmed by HSC are classified as Inceptisols. As young soils, deficient in phosphorus, Inceptisols require relatively high fertilization for high crop yield. Although Inceptisols are not 
In the early 1990s, water consumption on the island was about $180 \mathrm{mgd}$. The Hawaii County Water Department owns and operates 26 water systems. These systems accounted for $29 \mathrm{mgd}$ or $16 \%$ of the total amount of water withdrawn from all sources in 1990-1991. Agricultural irrigation systems accounted for about $24 \mathrm{mgd}$ or $13 \%$ of total water consumption. Closure of the sugar companies has reduced water consumed by agriculture. Private domestic, commercial, and other industrial systems consumed about 132 mgd or $71 \%$ of the total water used on the island. Industrial systems provide most of the water used in power generation plants. It is anticipated that the total water consumption on the island in 2010 will be about $299 \mathrm{mgd}$ and agricultural water use will be about $44 \mathrm{mgd}$ (Megumi Kon Inc., 1991). As a whole, the water capacity of the island easily meets anticipated demand.

The Hamakua district extends inland from the northern portion of the Hamakua Coast, covering the summit and upper areas of Mauna Kea, and terminates at the summit of Mauna Loa. Average rainfall in coastal areas ranges from 78 to 137 inches, decreasing to 15 inches a year at the summits of Mauna Kea and Mauna Loa. In the northeastern section of the district lie the Kohala Mountains where the district's median annual rainfall reaches a maximum of 160 inches at about 3,000 feet elevation.

Although annual rainfall in the HSC area is high and the total amount of water is sufficient for agriculture, irrigation was still used on some sugarcane lands at HSC. The water supply capacity and water consumption (in the early 1990s) in Hamakua are presented in Table 9-2. More surface water than groundwater was consumed in that area, largely for irrigating sugarcane. Hamakua District has abundant groundwater sources, which are used only sparingly. The release of surface water following the end of sugar production and the rich groundwater sources provide abundant water supplies for ethanol production in that area.

Table 9-2. Water supply capacity and water consumption in Hamakua.

\begin{tabular}{|c|c|c|c|}
\hline$\underline{\text { Source and Use }}$ & \multicolumn{3}{|c|}{$\frac{\text { Deliver Capacity }_{\text {(million gallons per day) }}^{\text {Source Capacity }}}{\text { Consum }}$} \\
\hline Surface Water & & & 22.0 \\
\hline Upper Hamakua Ditch & $<15$ & & \\
\hline Lower Hamakua Ditch & 40 & & \\
\hline Ground Water & & 201 & 4.4 \\
\hline Waimanu & & 110 & \\
\hline Honokaa & & 31 & \\
\hline Paauilo & & 60 & \\
\hline
\end{tabular}

1. Wilcox (1996).

2. Megumi Kon Inc. (1991).

Surface water for irrigation in Hamakua is provided mainly by two ditches, Upper Hamakua Ditch and Lower Hamakua Ditch. The locations of these two ditches are shown in Fig. 9-2. The Upper Hamakua Ditch was completed in 1907 and initially delivered $15 \mathrm{mgd}$. Water sources for the ditch included the Kawainui, Alakahi, and Koiawe tributaries of Wailoa stream. Water from this ditch began irrigating sugarcane in 1909, increasing average sugar yield from 2.9 to 4.1 tons per acre. The Lower Hamakua Ditch was opened in 1910, delivering water to the sugar mill and the plantation. It tapped the same water sources as the Upper Ditch, but at lower elevation. The ditch has an overall length of 24.8 miles, with an average flow of $40 \mathrm{mgd}$, initially, peaking at $61 \mathrm{mgd}$. These two ditches are owned by Hamakua Irrigation Company, a public utility, wholly owned by HSC (Hamakua Steering Committee, 1990). 
The Hawaii County Department of Water Supply operates three water supply systems in the Hamakua District. They are located in Ahualoa-Honokaa, Paauilo, and Kukuihaele, and provided about $0.95 \mathrm{mgd}$ water in 1991. Both surface water and groundwater feed these systems. There are several other domestic, military, and commercial systems in Hamakua.

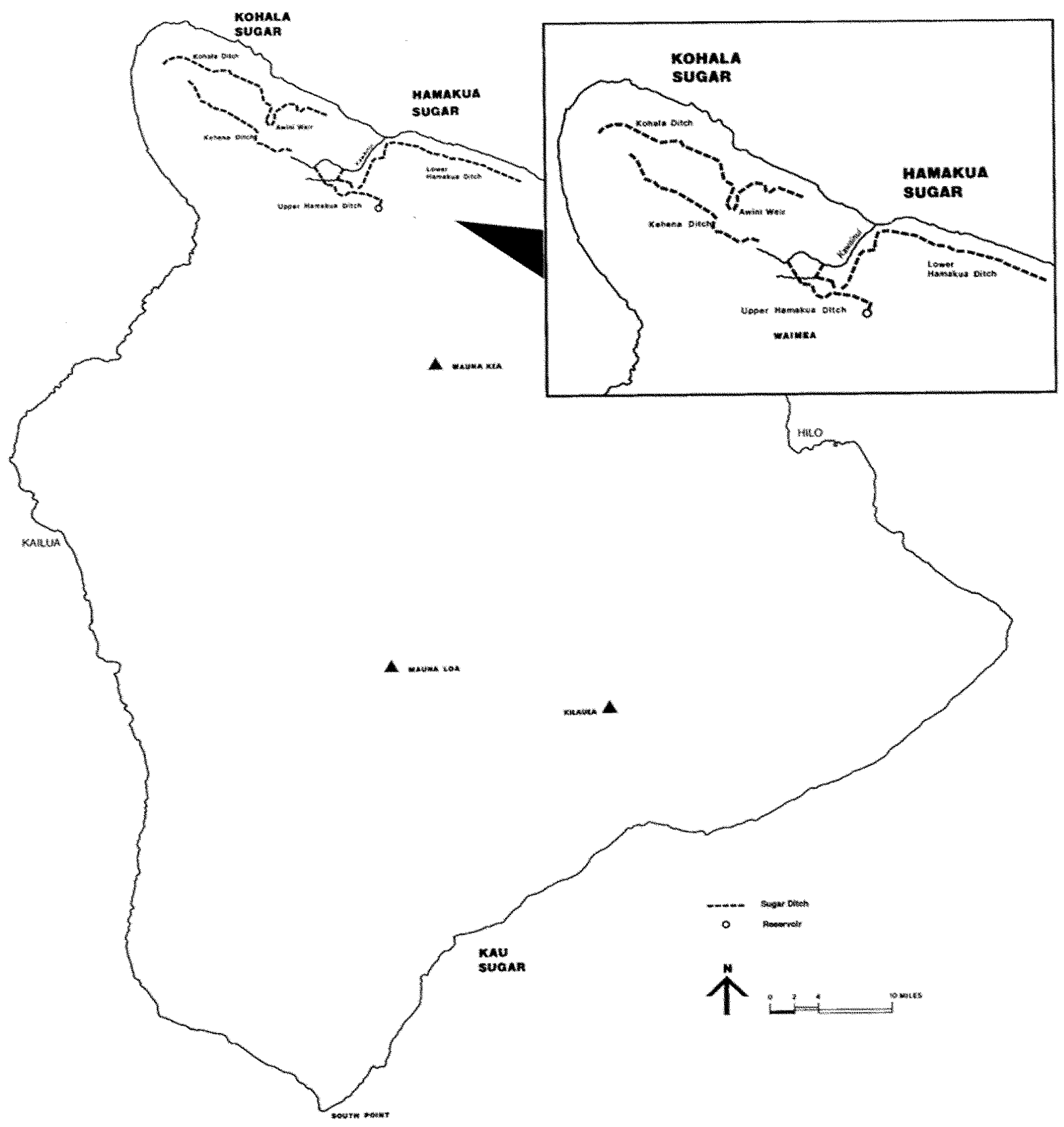

Fig. 9-2. Major water and ditch distribution in Hamakua area, Hawaii island.

Former HSC maintained two water systems for domestic use. One system taps water from the Lower Hamakua Ditch which is sand filtered before being distributed to the Paauhau Camp. The other system has a well source at the old Paauilo mill and serves the camps around Paauilo. A deep well source provided water for the sugar company's feedlot and slaughterhouse operations near Paauilo. The sugar mill at Haina drew 10 to $12 \mathrm{mgd}$ of surface water from the Lower Hamakua Ditch through a penstock for 
industrial cooling and other sugar mill uses. Most of these systems, developed by former HSC, became available for other uses after the closure of HSC in 1994. According to the water development plan (Megumi Kon Inc., 1991), the independent water supply systems at three locations, Ahualoa-Honokaa, Kukuihaele, and Pauuilo, will be upgraded to ensure sufficient water supplies for industrial and residential expansion in the Hamakua District.

\subsection{Transportation at HSC}

The roadway network on Hawaii island consists of state highways and county roads. The State built and maintains Highway 19 which runs from Hilo to Kamuela and connects Highway 11 to form a highway circle around the island. This highway circle is the major route for intra-island transportation. The State also maintains Highway 240 from Honokaa town to Kukuihaele, and several other highways. Some of these highways traverse the middle of island and some link the highway network to small towns (Table 9-3). The Department of Public Works in the County of Hawaii maintains a substantial network of roads throughout the island. Most of the County roadways service the rural homestead communities scattered throughout the area (Fig. 9-3).

Hamakua lies on the northeastern coast of the island and is about 35 miles from Hilo town, one of the major economic centers on the island. No harbors or airports are located along the Hamakua coast. Ground transportation is the primary mode for moving supplies and products from Hamakua to harbors and airports. Distances between Hamakua District and major shipping ports are summarized in Table 9-3.

Table 9-3. Major roads and ground transportation conditions in Hamakua.

\begin{tabular}{|c|c|c|}
\hline$\underline{\text { Road }}$ & Linkage & \\
\hline Highway 19 & \multicolumn{2}{|c|}{ Across Hamakua; part of highway network on the island. } \\
\hline Honokaa-Waipio Road & \multicolumn{2}{|c|}{ Links Honokaa to highway network. } \\
\hline Highway 220 & \multicolumn{2}{|c|}{ Links state park to highway network. } \\
\hline Ground Transportation & & $\underline{\text { Distance }}$ \\
\hline From & To & (miles) \\
\hline Paauhau & Hilo International Airport & 41 \\
\hline Paauhau & Keahole International Airport & 50 \\
\hline Paauhau & Waimea-Kohala Airport & 15 \\
\hline Paauhau & Hilo Harbor & 41 \\
\hline Paauhau & Kawaihae Harbor & 26 \\
\hline
\end{tabular}

Former HSC owned and maintained a substantial network of private agricultural roads in the Hamakua district, including a broad, paved cane haul spine system that runs from the upper Kukuihaele area to Ookala to serve the Haina mill (Fig. 9-4). This road network provided efficient transportation conditions for crop production (Hamakua Steering Committee, 1990). Some of these roadways are currently used for Eucalyptus production by Forest Solutions.

Hawaii island has two deep-draft harbors, Hilo Harbor and Kawaihae Harbor, that support overseas shipping service (Fig. 9-3). These two facilities serve both ends of the island for exporting of crops, cattle, and other commodities and for importing capital and consumer goods. Most fuel, equipment, supplies, and 
construction material are shipped to the island. Table 9-4 provides information on these two commercial harbors.

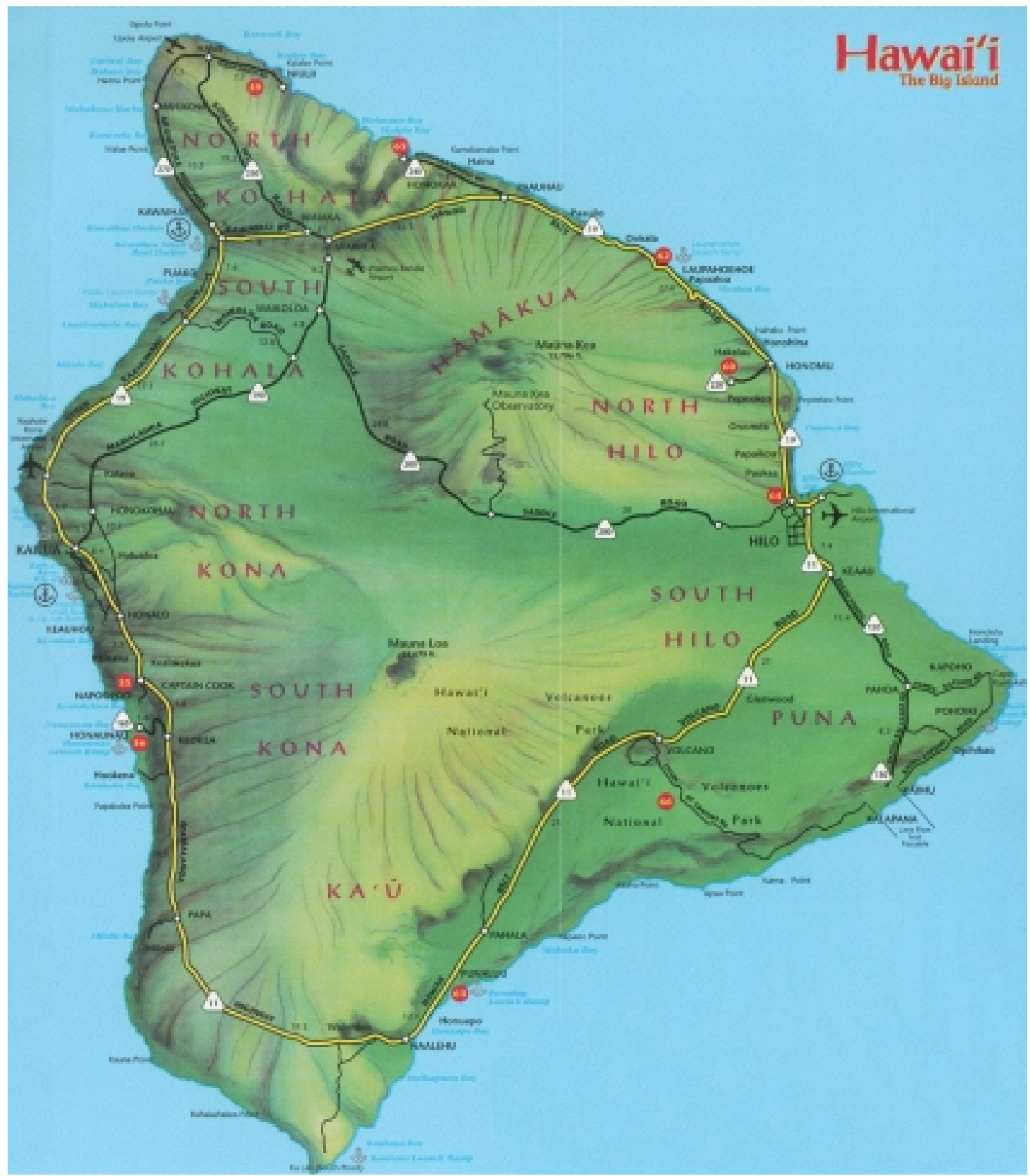

Fig. 9-3. Transportation on Hawaii island.

Air transportation is another important corridor to Hawaii island. There are two major commercial airports on the island, Hilo International Airport and Keahole International Airport, and two small airports, at Waimea-Kohala and Upolu. The Keahole-Kona airport provides overseas service and links Hawaii island with cities on the mainland and other countries. Passenger, cargo, and mail traffic though airports on the island are presented in Table 9-5. Hilo airport is located on the east cost of the island and Keahole airport is on the west coast of the island. Most transportation by air routes through these two airports. A small airport is located about 15 miles from Hamakua in Waimea-Kohala, which provides passenger and cargo services. 


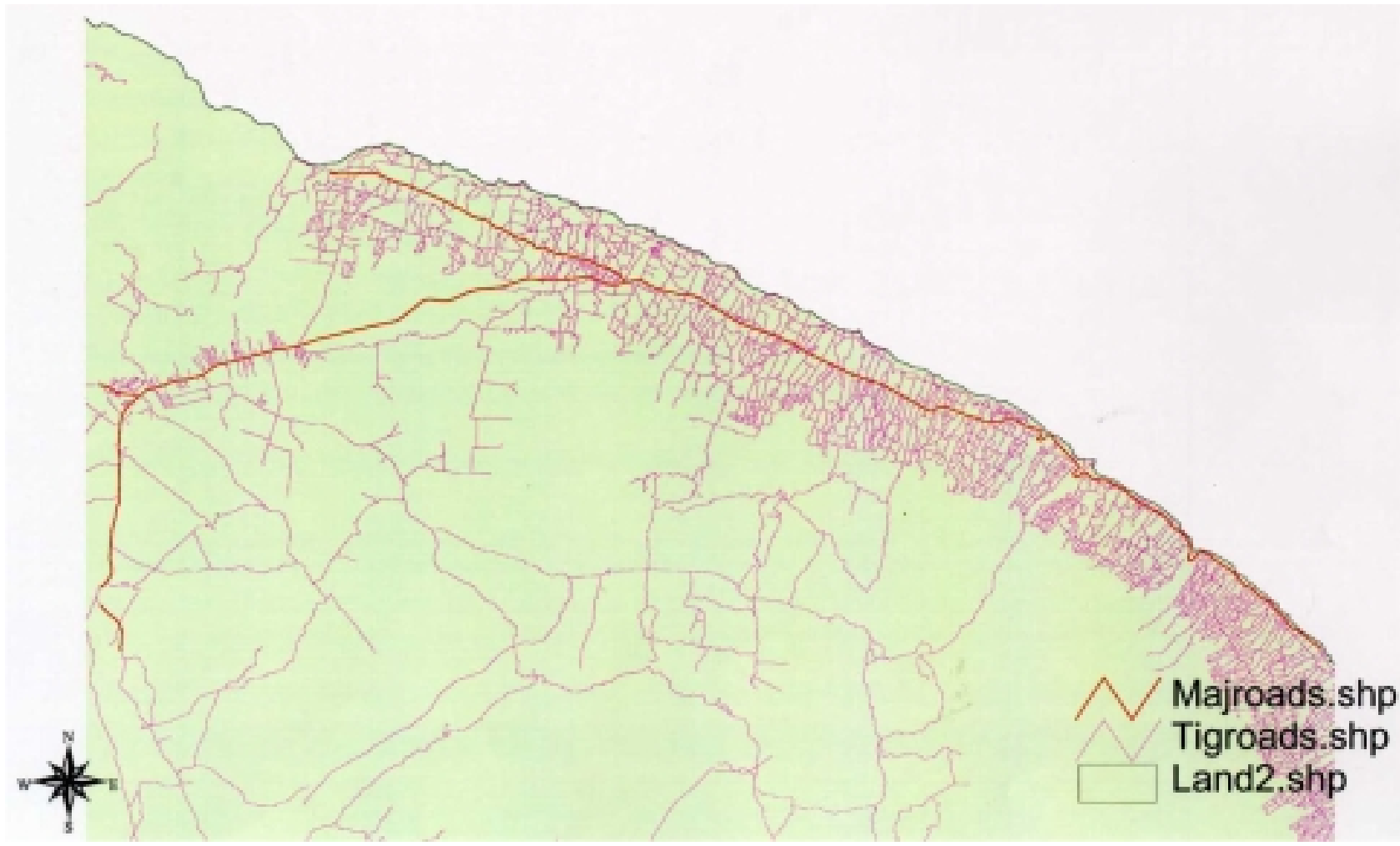

Fig. 9-4. Road network in former HSC area.

Table 9-4. Commercial harbors on Hawaii island ${ }^{1}$.

\begin{tabular}{|c|c|c|c|c|c|c|c|}
\hline \multirow[t]{2}{*}{$\underline{\text { Harbor }}$} & \multirow{2}{*}{$\frac{\text { Entrance }}{\underline{\text { Depth }}}$} & \multicolumn{3}{|c|}{$\underline{\text { Harbor basin }}$} & \multicolumn{3}{|c|}{$\underline{\text { Storage area }}$} \\
\hline & & $\frac{\text { Depth }}{\text { (feet) }}$ & $\frac{\text { Length }}{\text { (feet) }}$ & $\frac{\text { Width }}{\text { (feet) }}$ & (linear feet', & $\frac{\text { Shedded }}{(1,000 \text { squar }}$ & $\frac{\text { Open }}{\text { e feet) }}$ \\
\hline Hilo & 35 & 35 & 2,300 & 1,400 & 2,787 & 122 & 566 \\
\hline Kawaihae & 40 & 35 & 1,500 & 1,450 & 1,562 & 23 & 427 \\
\hline
\end{tabular}

Table 9-5. Passengers, cargo, and mail transported by airports on Hawaii island, 1997.

\begin{tabular}{|c|c|c|c|c|c|c|}
\hline \multirow[b]{2}{*}{$\underline{\text { Airport }}$} & \multicolumn{2}{|c|}{$\underline{\text { Passengers }}$} & \multicolumn{2}{|c|}{$\underline{\text { Cargo }}$} & \multicolumn{2}{|c|}{$\underline{\text { Mail }}$} \\
\hline & Enplaned & $\underline{\text { Deplaned }}$ & $\frac{\text { Enplaned }}{\text { (tor }}$ & Deplaned & $\frac{\text { Enplaned }}{\text { (ton }}$ & Deplaned \\
\hline Keahole-Kona & 157,671 & 213,268 & 3,750 & 1,616 & - & - \\
\hline Interlands & & & & & & \\
\hline Hilo & 819,946 & 849,368 & 15,774 & 11,966 & 1,251 & 2,268 \\
\hline Waimea-Kohala & 1,300 & 830 & 54 & 21 & 48 & 121 \\
\hline Keahole-Kona & $1,175,607$ & $1,081,611$ & 7,284 & 11,966 & 823 & 1,399 \\
\hline Upolu & - & 9 & - & - & - & - \\
\hline
\end{tabular}




\subsection{Electricity Service at HSC}

HELCO provides utility electricity service on Hawaii island. In 1994, HELCO sold 835 GWh. HELCO's own generators produced $588 \mathrm{GWh}$, or $64.6 \%$, of the $910 \mathrm{GWh}$ generated for utility use. The remainder was produced by independent power producers and cogenerators, and exported to the utility company for resale. On Hawaii island, the electrical system currently has a firm capacity of $202 \mathrm{MW}$. HELCO owns $155 \mathrm{MW}$, or $77 \%$. The remaining firm capacity is provided by Puna Geothermal Venture (25 MW) and the Hilo Coast Processing Company (HCPC) power plant (22 MW). The closure of HSC in 1994 eliminated $8 \mathrm{MW}$ of firm capacity from the system (State of Hawaii, 1995a). The electricity generation capacity on Hawaii island is presented in Table 9-6.

Table 9-6. Electrical generation capacity on Hawaii island.

\begin{tabular}{|c|c|c|c|}
\hline$\underline{\text { Owner }}$ & $\underline{\text { Fuel }}$ & Mode of Operation & $\frac{\text { Capacity }}{(\mathrm{MW})}$ \\
\hline HELCO & MSFO/Diesel & Firm Baseload & 52.6 \\
\hline HELCO & MSFO/Diesel & Firm Cycling & 55.3 \\
\hline HELCO & Diesel & Firm Peaking & 46.7 \\
\hline Puna Geothermal & Geothermal & Firm Baseload & 25 \\
\hline $\mathrm{HCPC}$ & Oil/Coal & Firm Baseload & 22 \\
\hline & & total - Firm Capacity & 201.6 \\
\hline HELCO & Hydro & Non-Firm & 3.35 \\
\hline Various & Hydro & Non-Firm & 0.81 \\
\hline Wailuku & Hydro & Non-Firm & 12 \\
\hline Kahua Ranch & Wind & Non-Firm & 0.4 \\
\hline Lalamilo & Wind & Non-Firm & 2.3 \\
\hline South Point & Wind & Non-Firm & 9.3 \\
\hline & Subtot & — Non-Firm Capacity & 28.16 \\
\hline & & Hawaii Capacity Total & 230 \\
\hline
\end{tabular}

The average electricity price on Hawaii island was about $\$ 0.20$ per kWh for residential users and about $\$ 0.17$ per $\mathrm{kWh}$ for other users in 1997 , about $80 \%$ higher than in 1988 . Table $9-7$ presents electricity consumption and prices on Hawaii island. One distinct feature of electricity generation on Hawaii island is the island's diverse energy sources, including geothermal, hydropower, biomass, and ocean thermal. Due to the closing of sugar companies and for other reasons, biomass and ocean thermal currently are not used as energy sources for power generation.

Hawaii's sugar industry was an important part of the island's electricity generation system. HSC and HCPC, combined, generated about $160 \mathrm{GWh}$ of power from biomass in 1994 and sold about $118 \mathrm{GWh}$ to the utility company. Power generation from bagasse ended on the island in September 1994 with the final harvest of sugarcane at Hamakua. Although the power plant at HSC has ceased operating, the HCPC power plant is still operating and provides electricity to the utility company using mostly coal and a small amount of diesel. Its contract with the utility company will terminate at the end of 1999, but HCPC is in the process of negotiating a new contract and plans to continue generating electricity (O'Brien, 1999). 
Table 9-7. Electricity consumption and prices on Hawaii island.

\begin{tabular}{|c|c|c|c|c|c|c|c|}
\hline \multirow[t]{2}{*}{$\underline{\text { Island }}$} & \multicolumn{3}{|c|}{$\frac{\text { Power Consumption }}{(\mathrm{GW})}$} & \multicolumn{2}{|c|}{$\frac{\text { Average Annual Use }}{(\mathrm{kWh} / \mathrm{user})}$} & \multicolumn{2}{|c|}{$\frac{\text { Average Rate }}{(\$ / \mathrm{kWh})}$} \\
\hline & Total & $\underline{\text { Residential }}$ & $\underline{\text { Others }}$ & Residential & Others & Residential & Others \\
\hline Hawaii, $1988^{1}$ & 612 & 243 & 369 & 6,322 & 46,834 & 0.11 & 0.10 \\
\hline Hawaii, $1997^{2}$ & 894 & 331 & 563 & 6,545 & 58,462 & 0.20 & 0.17 \\
\hline \multicolumn{8}{|c|}{ 1. State of Hawaii (1989). } \\
\hline
\end{tabular}

\subsection{Candidate Ethanol Crops and Their Output Potential at HSC Site}

The species of plants suitable for the former HSC area depends on cultivation conditions in the area. This area has high rainfall and most of its lands are steep. Sugarcane production in this area has had a long history but yields in Hamakua have been lower than in many other locations in the Hawaiian islands. It is also more difficult to use large mechanical equipment for cultivation and harvesting in the Hamakua region owing to the steep terrain. After the sugarcane plantation ceased operating in the early 1990s, a significant effort was made to convert the land to forestry, which finally took hold in recent years (Dudley, 1998). The objective of this forestry effort is to produce wood chips and other wood products. The forest will produce large amounts of residues that could be a source of biomass feedstock for ethanol production. Indeed, trees are a promising candidate for ethanol crop cultivation in this area.

Previous experiments conducted on Hawaii island have shown that Eucalyptus needs more water than Leucaena and are better adapted to wetter, higher elevation locations. Eucalyptus is selected as a preliminary candidate for ethanol-crop production at the HSC site. Fig. 9-5 shows a field prepared for Eucalyptus production by Forest Solutions (a company growing Eucalyptus in that area) on former HSC land. The potential yield from a 20,000 acre, unirrigated Eucalyptus plantation at that site is about 670 tons per day (dry matter basis). As discussed in Section 4, many other lands still are available in that area, leaving the potential for additional acreages of ethanol crop.

\subsection{Potential Bioresidues for Ethanol Production at HSC Site}

Energy crops can yield substantial quantities of feedstock for ethanol conversion at the HSC site. Residues produced by other agricultural activities on Hawaii island and MSW can also be used for ethanol conversion. If these biomass wastes can be supplied at large enough quantities to meet a substantial portion of the requirements of an ethanol plant, they can supplement or replace dedicated energy crops.

Although many kinds of agricultural crops including macadamia nuts, coffee, fruits, vegetables, and melons, are produced on Hawaii island, none is produced at a sufficiently large scale to generate large quantities of agri-residues.

The growing forest industry on the island has potential to generate large amounts of forest residues that can become an important resource to supplement ethanol crops as feedstocks for ethanol production. The primary objective of Eucalyptus production on the island is to produce wood chips. Eucalyptus residues — tree bark, leaves, stems, and small branches — constitute about 10 to $15 \%$ of the whole tree mass. The cellulose content in the tree bark is about $30 \%$ of the dry bark mass. The average contents of cellulose and hemicellulose in the bark are similar to those of the whole tree (Sjöström, 1981). If Eucalyptus were selected as a dedicated ethanol crop at the HSC site, using residues from existing or planned forest plantations such as Forest Solutions as feedstock should not negatively impact the ethanol conversion process and ethanol yield. 


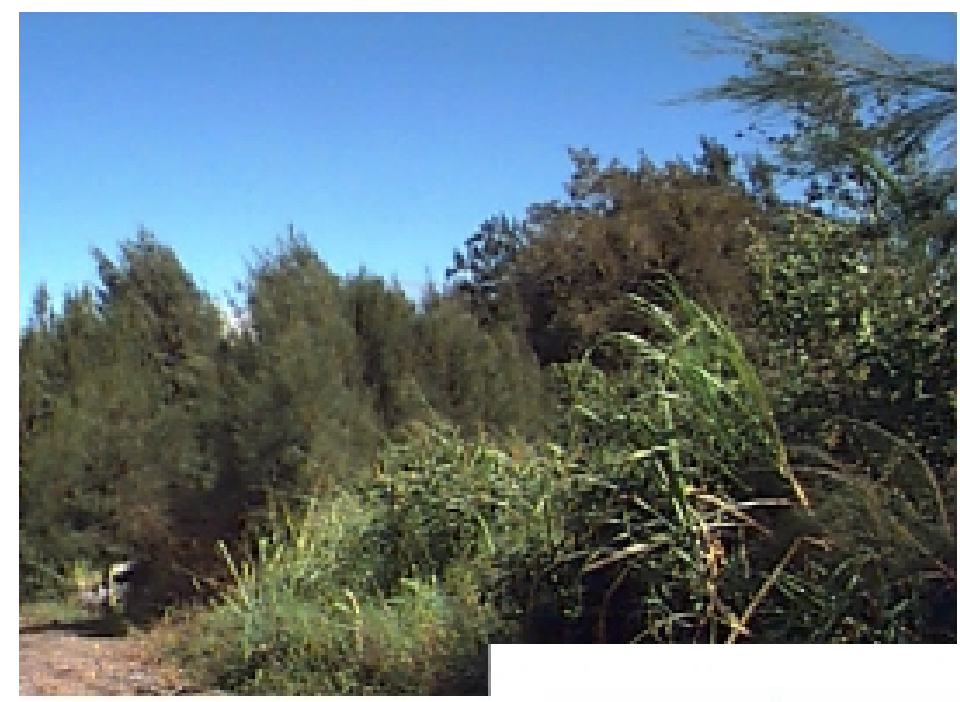

(a) Field before preparation.

(b) Field during preparation.
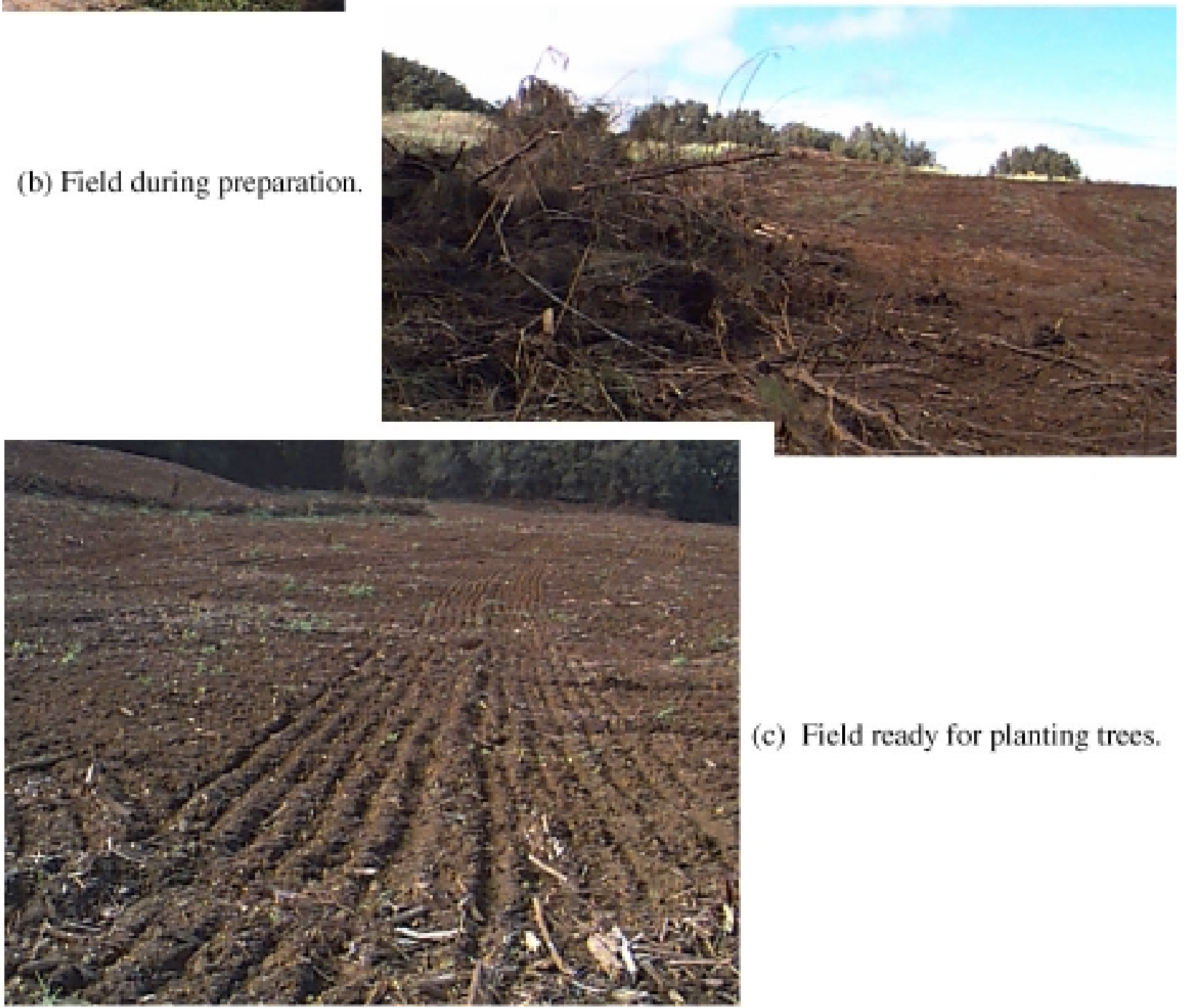

(c) Field ready for planting trees.

Fig. 9-5. Prepared land for Eucalyptus plantation.

Composition and quantity of MSW vary substantially, depending on location. Hawaii County has a resident population of about 120,000 and the travel industry adds a significant number of temporary residents. MSW contains green material from yards, hotels, golf courses, parks, and construction, but is 
difficult to collect due to logistical complications. One important component in MSW is paper waste. Paper waste is included in this investigation; all other forms of MSW are neglected.

Table 9-8 presents sources and quantities of agricultural residues and MSW which can supplement energy crops for ethanol production at the HSC site. The data suggest that, in total, more than 160 tons per day of residues and waste material can be supplied to an ethanol conversion facility on Hawaii island. The data indicate that very limited quantities of forest residues and MSW are available on the island. The option of importing large quantities of residues to the island to supplement biomass feedstocks to an ethanol conversion facility was discarded as being impractical and too costly.

Table 9-8. Potential quantities of residues for ethanol at HSC site.

$\underline{\text { Residues }}$

Quantities

(tons/year) (tons/day) ${ }^{4}$

Paper $^{1,2}$

(1991 data)

Old corrugated cardboard

Old newspaper

5,500

High-grade paper

Mixed paper

19,500

Subtotal

40,200

134

Forest Waste

Eucalyptus tree waste

9,000 30

Total

1. Shleser (1994).

2. STV/LYON Associates, Inc. (1995).

3. Dudley (1998).

4. Based on 300 days/year. 


\section{Summary and Conclusions}

Seven potential sites for producing biomass for ethanol conversion on the Hawaiian islands of Oahu, Kauai, Hawaii, and Maui were identified using technical and economic considerations, including land availability and suitability, crop yield and compatibility, and production cost. Three most suitable sites were selected from the seven candidates identified in the initial screening. Agronomic conditions and infrastructure for water, power, and transportation, yield potential for energy-crop production, and quantity of bioresidues available to supplement energy crops were evaluated for the three sites.

Salient findings of the evaluation are summarized below:

1. The State of Hawaii shows significant potential for ethanol production and utilization.

Because of unique geographical and other factors, Hawaii is highly vulnerable to interruptions in energy supplies. In spite of this vulnerability, Hawaii continues to rely on imported oil for $\sim 90 \%$ of its energy needs, by far the highest percentage for any state in the nation. These factors and their associated costs and risks make alternative (non-fossil) energy resources, such as wind, geothermal, ocean thermal, solar, and biomass energy, attractive for the State.

The State of Hawaii Energy Policy Statement reinforces that the adoption of alternate fuels is one of the most important components in the State's energy strategy. Utilization of alternative transportation fuels to gasoline and diesel fuel has been demonstrated several times in Hawaii. If ethanol were cost competitive with petroleum-based transportation fuels, the State of Hawaii would be an ideal location to produce, distribute, and use ethanol fuel.

2. Ample land resources exist in Hawaii for ethanol-crop production.

Hawaii is the only state in the nation with statewide land-use designations, including Conservation, Agricultural, Urban, or Rural. Lands in crops occupy only small fractions of the total lands zoned Agricultural on the islands of Oahu, Hawaii, Maui, and Kauai. Agricultural lands currently or formerly in crop production are especially well suited for ethanol-crop production, and large tracts of such lands are available for ethanol-crop production.

Downsizing of the sugarcane industry in Hawaii presents an unprecedented opportunity for establishing a new agri-energy industry. The acreage in sugarcane has decreased from about 255,000 acres in the 1930s to less than 70,000 acres today. Efforts have been made to offset the continuous loss in sugarcane acreage, mostly with diversified agriculture (e.g., coffee, flowers, and nursery products); however, these crops are not expected to occupy more than a small fraction of the lands previously in cane. Large quantities of productive and well-developed agricultural lands presently exist in Hawaii in "ready to plant" condition.

3. Former Waialua Sugar Company, Hawaiian Commercial and Sugar Company, and former Hamakua Sugar Company are the three most suitable sites for ethanol production.

An initial screening based on land availability yielded seven promising sites in areas zoned Agricultural, capable of producing more than 300 tons per day of biomass (dry-weight basis). The seven sites are located in Waialua and Ewa on the island of Oahu, Ka'u and Hamakua/North Hilo on the island of 
Hawaii, Lahaina and Wailuku/Makawao on the island of Maui, and Koloa/Lihue on the island of Kauai. Three best sites were selected from the seven candidates on the basis of land suitability, i.e., land ownership, topography, climate, and soil and other agronomic conditions. The three sites were: (1) former Waialua Sugar Company (WSCo) in Waialua on Oahu island, with 12,000 acres; (2) Hawaiian Commercial \& Sugar Company (HC\&S) in Wailuku/Makawao on Maui, with more than 20,000 acres; and (3) former Hamakua Sugar Company (HSC) in Hamakua/North Hilo on Hawaii island, with more than 20,000 acres.

4. The most promising crops for ethanol conversion in Hawaii include two grass species, sugarcane and banagrass, and two tree species, Eucalyptus and Leucaena.

Two grass species, sugarcane and banagrass, and two tree species, Eucalyptus and Leucaena, were identified as the most promising crops for ethanol production. Sugarcane, which formerly dominated agriculture in Hawaii, produces very high quantities of fiber and fermentable sugars (sugarcane grown commercially in Hawaii has an average dry-matter yield of $\sim 18$ tons per acre-year, consisting of about $60 \%$ fiber and $40 \%$ sugar). Long cultivation history and well-developed infrastructure give sugarcane inherent advantages over other crops.

A number of biomass experiments have been performed in Hawaii to identify other promising highyielding energy crops. Banagrass has been demonstrated to attain very high yields and shows strong commercial potential as an energy crop. Banagrass and sugarcane call for similar cultural practices, agronomic conditions, and production infrastructure. They share similar production operations (although some unit operations for banagrass are simpler and less costly than corresponding sugarcane operations). The projected yield of banagrass, based on several trials performed in Hawaii, is $\sim 22$ tons per acre-year for irrigated fields and $\sim 18$ tons per acre-year for unirrigated fields. Of the tree species, Leucaena and Eucalyptus offer the best commercial potential for energy cropping, owing to their high yields. Numerous small- and medium-scale trials in Hawaii have provided guidelines for optimizing the production of these tree crops. Based on large-plot field trials and on near-commercial-scale plantings in Hawaii, Leucaena and Eucalyptus are projected to produce commercial yields of $\sim 10$ tons per acre-year. A recently established Eucalyptus plantation on the island of Hawaii will provide additional experience in large-scale tree cultivation.

5. $\quad$ The estimated cost of producing biomass feedstock ranges from $\$ 54$ to $\$ 85$ per ton (dry-matter basis). Irrigation, harvesting, and transporting represent the largest cost factors in producing ethanol crops.

Production costs for one sugarcane plantation in Hawaii were used as the basis for this cost analysis on ethanol-crop production. The estimated cost for producing sugarcane for conversion to ethanol, FOB conversion-facility gate, is approximately $\$ 85$ per ton (dry-matter basis). The equivalent cost of production for banagrass is about $\$ 66$ per ton, $\$ 54$ per ton for Eucalyptus, and $\$ 85$ per ton for Leucaena (dry-matter basis). Table 10-1 presents major assumptions and costs (FOB conversion-facility gate) for the four candidate crops (the cost of land holding is not included in the cost figures). 
Table 10-1. Estimated costs for producing ethanol crops in Hawaii.

\begin{tabular}{|lrrrrr|}
\hline & \multicolumn{5}{c}{ Crop } \\
& $\underline{\text { Sugarcane }}$ & & Banagrass & Eucalyptus & $\underline{\text { Leucaena }}$ \\
Dry matter yield (tons/acre-year) & 18 & 22 & 9 & 10 \\
Average crop age (years) & 2 & 0.67 & 5 & 5 \\
Number of ratoons & 0 & 5 & 0 & 3 \\
Irrigation regime & irrigated & irrigated & unirrigated & irrigated \\
Cost (\$/tons, dry-basis) & 85 & 66 & 54 & 85 \\
\hline
\end{tabular}

Irrigation, harvesting, and transporting are the major cost factors in energy-crop production in Hawaii. Irrigation represents the largest fraction of total production cost for sugarcane, banagrass, and Leucaena (Eucalyptus is assumed to be rain-fed). Elimination or reduction of irrigation can significantly reduce biomass production cost. Improvements in harvesting and transporting systems can also help to lower production cost. The unit cost of delivered biomass can be reduced further by increasing crop yield and increasing the number of ratoon or coppice crops obtainable from a single plant crop.

6. Each site has large tracts of lands to produce substantial quantities of biomass feedstock for ethanol conversion. Agricultural residues and MSW are available to supplement the energy crops at each site.

Each of the selected sites is or has been in intensive agriculture for decades. Most lands that have been taken out of intensive agriculture have high yield potential and can be converted to ethanol-crop production relatively easily. Crops were selected for evaluation at each site based on their compatibility with the site. The following combinations of crops and acreages capable of providing more than 300 tons of biomass per day to an ethanol conversion facility were analyzed (Table 10-2).

Table 10-2. Acreages and quantities of biomass supplies at three sites.

\begin{tabular}{|lrlc|}
\hline Site & $\underline{\text { Acreage }}$ & Crop & Biomass Supply \\
(acres) & & (tons/day) \\
WSCo on Oahu & $\sim 12,000$ & Sugarcane & $720^{1}$ \\
& & Banagrass & $880^{1}$ \\
HC\&S on Maui & $\sim 20,000$ & Sugarcane & $1,200^{1}$ \\
& & Banagrass & $1,467^{1}$ \\
HSC on Hawaii & $\sim 20,000$ & Eucalyptus & $667^{2}$ \\
1. Assumes irrigated conditions. & & \\
2. Assumes unirrigated conditions. & & \\
\hline
\end{tabular}

Residues produced by other agricultural activities in Hawaii and MSW contain significant amounts of lignocellulosic material that can supplement or replace dedicated energy crops as feedstocks for ethanol conversion. Agricultural residues considered include those from sugarcane, pineapple, macadamia nut, and coffee production. 
The composition and quantity of MSW vary widely depending on location. One important component in MSW is paper waste which was included in this investigation (all other forms of MSW are neglected). In total, a substantial amount of residues and waste material can be collected on Oahu and Maui to supplement dedicated ethanol crops at the WSCo and HC\&S sites, respectively. The quantities of residues available at various sites are presented in Table 10-3.

Table 10-3. Quantities of residues available at three sites.

\begin{tabular}{|c|c|c|}
\hline$\underline{\text { Site }}$ & $\underline{\text { Residue }}$ & $\frac{\text { Quantity }}{\text { (tons/day) }}$ \\
\hline \multicolumn{3}{|c|}{ WSCo on Oahu } \\
\hline & Paper (1991 data) & 945 \\
\hline & Total & 945 \\
\hline \multicolumn{3}{|c|}{ HC\&S on Maui } \\
\hline & Paper (1991 data) & 233 \\
\hline & Sugarcane bagasse (1997 data) & 1,038 \\
\hline & Sugarcane trash (1997 data) & 560 \\
\hline & Pineapple silage & 27 \\
\hline & Total & 1,858 \\
\hline \multicolumn{3}{|c|}{ HSC on Hawaii } \\
\hline & Paper (1991 data) & 134 \\
\hline & Forest residues (Eucalyptus plantation) & 30 \\
\hline & Total & 164 \\
\hline
\end{tabular}

7. The infrastructure at each site, including those for electricity, water, and transportation, is adequate for energy-crop production and for ethanol conversion.

In addition to high yield and acceptable production cost, successful energy-crop production and ethanol conversion depend on the adequacy of infrastructure at the plantation and the conversion facility, including those for electricity, water, and transportation. All three sites have abundant and stable groundwater resources. Although the amount of surface water available varies with rainfall and the capacity of the collection system, each site has good surface water collection and delivery systems. The supply capacity for water sources at each site is adequate to meet the requirements of ethanol-crop production.

Oil, coal, biomass and other types of fuels are used for power generation in Hawaii. Electricity generation capacity comfortably exceeds electricity consumption on each island housing the three candidate sites. The existing power distribution systems at the three sites can easily serve energy-crop production and ethanol conversion.

Ground transportation on each island relies on the existing system of highways. Each site is connected to the primary transportation network on the island and is easily accessible to most areas of the island, including airports and harbors. The agricultural land at each site is served by a complete road network which provides efficient transportation conditions for the biomass feedstock to reach the ethanol 
conversion facility. Each island that houses a selected biomass production site has at least one deep-draft harbor with facilities for containerized cargo. The distance from each site to the nearest harbor or airport on the island ranges from 2 miles to 50 miles. Closure of sugar plantations at the WSCo and HSC sites has idled valuable inventories of other supporting infrastructure, such as drainage systems, processing facilities, fabrication and maintenance shops, and warehouses. The existing infrastructure at each site is well situated and equipped to serve a new biomass-ethanol industry. 


\section{References}

Alexander, A.G. 1985. The Energy Cane Alternative. Sugar Series \#6. Elsevier Science Publishing Co., Inc. New York.

County of Hawaii, Department of Research and Development. 1997. Data Book - Hawaii. Hilo, Hawaii.

County of Maui, Water Department, Planning Department. 1990. Water Use and Development Plan. Report. March 21.

County of Maui, Office of Economic Development. 1997. Maui County Data Book 1996 - 1997. July, Maui.

Cundiff, J.S. and Harris, W.L. 1995. Maximizing Output - Maximizing Profit. In Resource, February.

Dale, R.H. 1978. A ground-water inventory of the Waialua basal-water body, island of Oahu, Hawaii. Report prepared with Board of Water Supply, City and County of Honolulu.

Decision Analysts Hawaii, Inc. 1989. Hawaii's Sugar Industry and Sugarcane Lands: Outlook, Issues and Options. Report prepared for State of Hawaii, Department of Business and Economic Development. April.

Dudley, N.S. 1990. Performance and Management of Fast-Growing Tropical Trees in Diverse Hawaiian Environments. MS Thesis in Agronomy and Soil Science. University of Hawaii.

Dudley, N.S. Forester, Hawaii Agricultural Research Center. Personal communication, July 7, 1998.

Ekern, P.C. 1975. Land Disposal of Sewage Effluent: Mililani Study. In Water Resources Seminar Series, No. 6. Water Resources Research Center, University of Hawaii at Manoa, June.

Fleisch, Herve. Research Director, Maui Pineapple Company. Personal communication, April 6, 1998.

Hamakua Steering Committee. 1990. Hamakua Regional Plan: From Kaiaakea to Waipio. November.

Hartsough Bruce. Agricultural Engineering Department, University of California, Davis. Personal communication, October 22, 1998.

Hawaii Agricultural Statistics Service. 1992. Statistics of Hawaiian Agriculture 1991. Honolulu.

Hawaii Agricultural Statistics Service. 1996. Statistics of Hawaiian Agriculture 1995. December, Honolulu.

Hawaii Agricultural Statistics Service. 1997. Statistics of Hawaiian Agriculture 1996. In http://www.nass.usda.gov/hi/.

Hawaii Natural Energy Institute. 1990. Hawaii Integrated Biofuels Research Program, Final Report, Phase II. SERI Subcontract No. XK-8-18000-1.

Hawaii Natural Energy Institute. 1992. Hawaii Integrated Biofuels Research Program, Final Report, Phase III. NREL Subcontract No. XN-0-19164-1.

Hawaii Natural Energy Institute. 1993. Hawaii Integrated Biofuels Research Program, Final Report, Phase 5. NREL Subcontract No. XZ-2-12025-1.

Hawaii Natural Energy Institute. 1994. Hawaii Biomass Resources Database.

Hawaiian Sugar Planters' Association. 1989. Hawaiian Sugar Manual 1989. Honolulu.

Hawaiian Sugar Planters' Association. 1993. Hawaiian Sugar Manual 1993. Honolulu.

Hawaiian Sugar Planters' Association. 1994. Hawaiian Sugar Manual 1994. Honolulu.

Hawaiian Sugar Planters' Association. 1995. Hawaiian Sugar Manual 1995. Honolulu. 
Hawaiian Sugar Planters' Association. 1996a. Hawaiian Sugar Manual 1996. Honolulu.

Hawaiian Sugar Planters’ Association. 1996b. HSPA Annual Report 1996. Honolulu.

Hawaiian Sugar Planters’ Association. 1997. HSPA Annual Report 1997. Honolulu.

Hooser, Gary (editor). 1994. Kauai Data Book. H \& S Publishing, Kapaa, Kauai.

Hubbard, H.M., Kinoshita, C.M. 1993. Investigation of Biomass-for-Energy Production on Molokai, Research report, Hawaii Natural Energy Institute.

Infante, E.M. 1993. State: No Sign of Risk to People. In Star Bulletin/Honolulu Advertiser, January 3.

Kilham, Phoebe. 1996. A Geographical Analysis of Change in a Hawaiian Sugarcane Plantation. Ph.D. dissertation, Department of Agronomy and Soil Science, University of Hawaii at Manoa. May.

Kinoshita, C.M. 1984. Energy Efficiency of the Hawaiian Sugar Industry. In IGT Symposium of Energy from Biomass and Wastes VIII, pp. 548-570.

Kinoshita, C.M. 1988. Composition and Processing of Burned and Unburned Cane in Hawaii. International Sugar Journal. V. 90, No. 1070. pp. 34-37.

Kinoshita, C.M. 1998. Eucalyptus feedstock composition (personal data).

Kinoshita, C.M.; Ishimura, D.M. 1995. Production of Biomass for Electricity Generation on the Island of Oahu, Prepared for Hawaiian Electric Company, Inc., Hawaii Natural Energy Institute.

Kinoshita, C.M.; Masutani, S.M.; Turn, S.Q.; Ishimura, D.M. 1996. Preliminary Engineering Design of 5 and 20 MWe Biomass Gasifier-Based Electric Power Stations in Hawaii, Stage 1: Initial Cycle Analysis, Hawaii Natural Energy Institute.

Kinoshita, C.M.; Staackmann, M. 1994. Hawaii Energy Strategy Development, Project 5: Transportation Energy Strategy, Prepared for Parsons, Brinckerhoff, Quade and Douglas, Inc. and State of Hawaii, Department of Business, Economic Development and Tourism; Energy Division, Hawaii Natural Energy Institute.

Mason, S. 1994. Meeting with C.M. Kinoshita and R. Shleser at the Pacific International Center for High Technology Research.

McCall, W.W. 1973. Soil Classification in Hawaii. Cooperative Extension Service, University of Hawaii. Circular 476, January.

Megumi Kon, Inc. 1991. Hawaii County Water Use and Development Plan. Report prepared for Department of Water Supply, County of Hawaii. December.

Moncur, James E.T. 1994. Water for Honolulu: Use, Reallocation, and Institutional Change. In Metropolitan Water Use Conflicts in Asia and the Pacific, ed. J.E. Nickum, and K.W. Easter. Westview Press, Boulder.

Moore, Randall. Department Manager, Hawaiian Commercial \& Sugar Co. Personal communication, April 29, 1998.

Morbark, Inc. 1998. Product Guide.

Nohara, Wesley. Farm Manager, Maui Pineapple Company. Personal communication, April 6, 1998.

O’Brien, Niel, Plant Superintendent of Hilo Coast Processing Company. 1999. Telephone conversation. April 6.

Osgood, R.V. and Dudley, N. 1987. Establishment of Biomass-to Energy Research Facilities, Prepared for Hawaii Department of Planning and Economic Development, Alternate Energy Branch, Contract 20033. HSPA Experiment Station. 
Osgood, R.V. and Dudley, N.S. 1993. Comparative Study of Biomass Yields for Tree and Grass Crops Grown for Conversion to Energy. Hawaiian Sugar Planters' Association. State of Hawaii Contracts $18817,20033,22823,27626,32116$.

Pacific International Center for High Technology Research. 1994. Sustainable Biomass Energy Program Hamakua Project. Final draft report, October.

Phillips, V.D. (Principal Investigator). 1993. Renewable Energy Resources Assessment Project of the Hawaii Energy Strategy — Phase 1 Report, Biomass Resources. Prepared for R. Lynette \& Associates, Inc. April 15.

Phillips, V.D.; Singh, D.; Merriam, R.A.; Khan, M.A.; Takahashi, P.K. 1992. Land Available for Biomass Crop Production in Hawaii. In Hawaii Integrated Biofuels Research Program, Final Subcontract Report, Phase III. Hawaii Natural Energy Institute. NREL/TP-230-46734. May.

Schmitt, R.J. 1973. The Dynamics of Water Masses and Nutrients in the South Fork of the Wahiawa Reservoir. M.S. Thesis, Department of Civil Engineering, University of Hawaii at Manoa, August.

School of Ocean and Earth Science and Technology. 1997. A Report 1995 and 1996. School of Ocean and Earth Science and Technology, University of Hawaii.

Serno, Mike. 1998. Controller, Pioneer Mill Company. Personal communication, April 7.

Shleser, Robert. 1994, Ethanol Production in Hawaii, Process, Feedstocks, and Current Economic Feasibility of Fuel Grade Ethanol Production in Hawaii, Prepared for State of Hawaii, Department of Business, Economic Development \& Tourism.

Sjöström, Eero. 1981. Wood Chemistry: Fundamental and Application. Academic Press, New York.

State of Hawaii, Department of Business, Economic Development \& Tourism. 1989. Databook 1989. Honolulu, Hawaii.

State of Hawaii, Department of Business, Economic Development \& Tourism. 1995a. Hawaii Energy Strategy, Report. October.

State of Hawaii, Department of Transportation, 1995b. Official Transportation Map-State of Hawaii. Honolulu, Hawaii.

State of Hawaii, Department of Business, Economic Development \& Tourism. 1997. State of Hawaii Data Book 1996. In http://www.hawaii.gov/dbedt/index.html.

State of Hawaii, Department of Business, Economic Development \& Tourism. 1998a. Quarterly Statistical \& Economic Report. In http://www.hawaii.gov/dbedt/index.html.

State of Hawaii, Department of Business, Economic Development \& Tourism. 1998b. Databook 1997. Honolulu, Hawaii.

STV/LYON Associates, Inc. 1995. Solid Waste Integrated Management Plan Update. Final report for City and County of Honolulu, Department of Public Work.

Sylvester, Joseph. 1998. Crop Control Superintendent, Armfac Sugar Kauai. Personal communication, May 5.

Tanabe, Yoshiaki, Vice President of Waialua Sugar Company. 1999. Telephone conversation, April 6.

Tew, T. L. 1989, Hawaii Integrated Biofuels Research Program, Phase I, Final Report. Hawaii Natural Energy Institute, HNEI 89-1004.

Thain, Jim. Field Manager, Forest Solutions, Paauilo, Hawaii. Personal communication, December 11, 1998.

Troy, May (editor). 1982. Hydropyrolysis of Biomass to Produce Liquid Hydrocarbon Fuels. Report on Energy Tree Farm Workshop No. 2. DOE Grant No. DE-FG01-80RA50324. 
United States Department of Agriculture. 1988. Sugar and Sweetener Situation and Outlook Report. Economic Research Service Report SSRV13N3, September.

United States Department of Agriculture Soil Conservation Service in Cooperation with the University of Hawaii Agricultural Experiment Station. 1972. Soil Survey of Islands of Kauai, Oahu, Maui, Molokai, and Lanai, State of Hawaii, August.

University of Hawaii at Hilo, Department of Geography. 1998. Atlas of Hawaii, third edition. University of Hawaii Press, Honolulu.

University of Hawaii, Department of Geography. 1983. Atlas of Hawaii, second edition. University of Hawaii Press, Honolulu.

University of Hawaii, Land Study Bureau. 1965. Detailed Land Classification — Island of Hawaii. In L. S. Bulletin No. 6, November.

University of Hawaii, Land Study Bureau. 1967a. Detailed Land Classification — Island of Maui. In L. S. Bulletin No. 7, May.

University of Hawaii, Land Study Bureau. 1967b. Detailed Land Classification — Island of Kauai. In L. S. Bulletin No. 9, December.

University of Hawaii, Land Study Bureau. 1972. Detailed Land Classification — Island of Oahu. In L. S. Bulletin No. 11, December.

Wachi, George. Field Superintendent, Gay \& Robinson, Inc. Personal communication, May 5, 1998.

Waialua Sugar Company. 1994. Proposal for Large Scale Production and Marketing of Agricultural Products at Waialua Sugar Co., In. March.

Walters, Gerald A. 1981. Why Hawaii is changing to the dibble-tube system of reforestation. Journal of Forestry. 79(11), 743-745.

Whitesell, C.D.; Debell, D.S.; Schubert, T.H.; Strand, R.F.; Crabb, T.B. 1992. Short-Rotation Management of Eucalyptus: Guidelines for Plantation in Hawaii. General Technical Report PSW-GTR-137, U.S. Department of Agriculture, Forest Service, Pacific Southwest Research Station.

Wilcox, Carol. 1996. Sugar Water, Hawaii's Plantation Ditches. University of Hawaii Press. Honolulu. Wiselogel, Art. 1998. National Renewable Energy Laboratory. Personal communication (facsimile), July 16.

Wu, K.K., and Tew, T.L.. 1989. Energy Studies of Sugarcane and Napiergrass. Annual Report 1989, Experiment Station, Hawaiian Sugar Planters’ Association. pp. 64-66. 